\title{
Monetary Policy and Financial Stability: Cross-Country Evidence
}

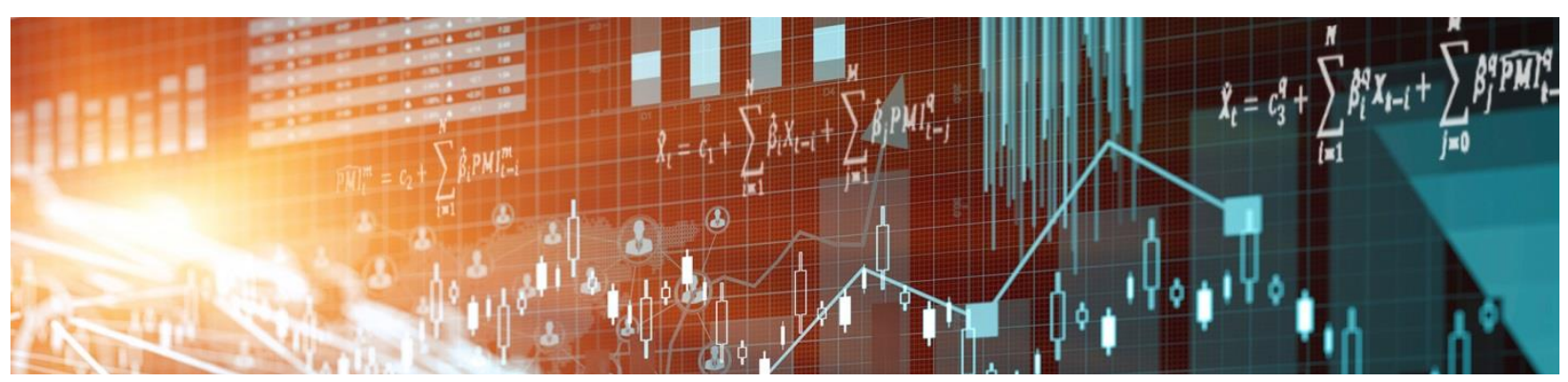

by Christian Friedrich, Kristina Hess and Rose Cunningham 
Bank of Canada Staff Working Paper 2015-41

November 2015

\title{
Monetary Policy and Financial Stability: Cross-Country Evidence
}

\author{
by \\ Christian Friedrich, Kristina Hess and Rose Cunningham \\ International Economic Analysis Department \\ Bank of Canada \\ Ottawa, Ontario, Canada K1A 0G9 \\ cfriedrich@bankofcanada.ca
}




\section{Acknowledgements}

We would like to thank, without implicating, Michael Ehrmann, Césaire Meh, Bob Fay, Oleksiy Kryvtsov, Miguel Molico, Greg Bauer, Michael Francis, Yuriy Gorodnichenko, Enisse Kharroubi, Alessandro Barattieri, Gregor Bäurle and Chandler Lutz for valuable comments on the project and the paper, all seminar participants at the Bank of Canada, and all conference participants at the 2015 Annual Conference of the Canadian Economics Association, Toronto; the 2015 Joint Central Bank Conference, Bern; and the 2015 ReCapNet Conference, Mannheim. We would also like to thank Bryce Shelton for excellent assistance in the data collection process and Geoffrey Halmo for valuable technical assistance with the text search. 


\begin{abstract}
Central banks may face challenges in achieving their price stability goals when financial stability risks are present. There is, however, considerable heterogeneity among central banks with respect to how they manage these potential trade-offs. In this paper, we review the institutional and operational policy frameworks of ten central banks in major advanced economies and then assess the effect of financial stability risks on their monetary policy decisions according to these frameworks. To do so, we construct a timevarying financial stability orientation (FSO) index that quantifies a central bank's policy orientation with respect to financial stability that spans the major viewpoints of the literature: "leaning against the wind" versus "cleaning up after the crash." The index encompasses three dimensions: (i) the nature of the statutory frameworks, (ii) the extent of the regulatory tool kit, and (iii) the prominence of financial stability references in central bank monetary policy statements. We then include our FSO index in a modified Taylor rule, which is estimated using a cross-country panel of up to ten central banks for the period from 2000Q1 to 2014Q4. We find that in episodes of high financial stability risks, measured by a strongly positive credit to GDP gap, "leaning-type" central banks, i.e., those with a high FSO index value, appear to account for financial stability considerations in their monetary policy rate decisions. For "cleaning-type" central banks, we do not find this to be the case. Our baseline specification suggests that a representative leaning-type central bank's policy rate is about 0.3 percentage points higher when financial stability risks are present than the policy rate of a representative cleaning-type central bank. We also find that the strength of this response increases in the additional presence of a house price boom but not so for the simultaneous occurrence of an equity price boom.
\end{abstract}

JEL classification: E5, E4, G01

Bank classification: Monetary policy framework; Financial stability; International topics

\title{
Résumé
}

L'atteinte des objectifs des banques centrales en matière de stabilité des prix peut présenter des défis lorsque des risques pèsent sur la stabilité financière. Les banques centrales gèrent toutefois très différemment les unes des autres les arbitrages potentiels qui découlent de ces deux pôles. Dans cette étude, nous examinons les cadres de politique institutionnels et opérationnels de dix banques centrales de grandes économies avancées, puis évaluons l'incidence des risques relatifs à la stabilité financière sur leurs décisions de politique monétaire à la lumière de ces cadres. Pour ce faire, nous construisons un indice quantitatif qui vise à mesurer l'orientation de la politique des banques centrales en 
ce qui a trait à la stabilité financière. Cet indice varie dans le temps et englobe les deux points de vue adoptés par les banques centrales recensés dans la littérature : la prévention de la formation de bulles et le nettoyage des dégâts après l'éclatement des bulles. L'indice mesure trois aspects : 1) la nature des cadres législatifs, 2) la panoplie des outils réglementaires et 3) l'importance accordée à la stabilité financière dans les énoncés des banques centrales sur leur politique monétaire. Nous incluons ensuite notre indice dans une règle de Taylor modifiée, estimée au moyen d'un panel transnational comptant jusqu'à dix banques centrales, pour la période allant du premier trimestre de $2000 \mathrm{au}$ quatrième trimestre de 2014. Nous constatons que durant les épisodes de risques d'instabilité financière élevés, soit lorsque l'écart du ratio crédit/PIB est fortement positif, les banques centrales qui choisissent de prévenir l'apparition de bulles (autrement dit celles pour lesquelles l'indice a une valeur élevée) semblent tenir compte de considérations liées à la stabilité financière dans les décisions relatives à leur taux directeur. Pour les banques centrales qui préfèrent nettoyer les dégâts après l'éclatement d'une bulle, ce constat ne s'applique pas. Selon la spécification de référence, lorsqu'il existe des risques pour la stabilité financière, le taux directeur des banques centrales qui optent pour la prévention est habituellement d'environ 0,3 point de pourcentage audessus de celui d'une banque centrale qui préfère nettoyer après-coup. Nous estimons également que la vigueur de cette réaction du taux directeur s'accroît en présence d'un boum des prix de l'immobilier résidentiel, mais que ce n'est pas le cas lors de l'occurrence simultanée d'un boum des cours des actions.

Classification JEL : E5, E4, G01

Classification de la Banque : Cadre de la politique monétaire; stability financière;

Questions internationales 


\section{Non-Technical Summary}

Central banks may face challenges in achieving their price stability goals in the presence of financial stability risks. There is, however, considerable heterogeneity among central banks with respect to how they manage these potential trade-offs. In this paper, we review the institutional and operational policy frameworks of ten major advanced economy central banks and then assess the impact of financial stability risks on their monetary policy decisions according to these frameworks. In particular, our analysis helps quantifying how changes in institutional frameworks or in the regulatory policy tool kit alter the effect on the interest rate that arises from using monetary policy to address financial stability concerns.

Based on our assessment of institutional and operational policy frameworks, we construct a timevarying financial stability orientation (FSO) index that quantifies a central bank's policy orientation with respect to financial stability that examines the "leaning against the wind" and the "cleaning up after the crash" viewpoints that are found in the literature. The FSO index encompasses three dimensions: (i) the nature of the statutory frameworks, (ii) the extent of the regulatory tool kit, and (iii) the frequency of financial stability references in central bank monetary policy statements. We then include our FSO index in a modified Taylor rule, which is estimated using a cross-country panel of up to ten central banks for the period from 2000Q1 to 2014Q4. Thus, our empirical analysis assesses how different types of central banks - indicated by different values of the FSO index - conduct monetary policy in the presence of financial stability risks.

Our results indicate that at times when central banks obtain a high-index value (leaning-type central banks), they appear to consider financial stability risks in their interest rate decision, whereas when central banks obtain low-index values (cleaning-type central banks), they do not. Our main specification suggests that when financial stability risks, measured by a strongly positive credit-to-GDP gap, are present, a representative leaning-type central bank's policy rate is about 0.3 percentage points higher than the policy rate of a representative cleaning-type central bank. An extension of our analysis to joint financial stability risks in credit and asset markets shows that the strength of the interest rate response for leaning-type central banks increases in the additional presence of a house price boom but not so for the simultaneous occurrence of an equity price boom.

We end by conducting a preliminary assessment of the impact of leaning behavior on the outcome of macroeconomic variables, such as inflation and output. As a part of this exercise, we find that leaning-type central banks respond, on average, less to deviations from the inflation or a potential output target. This suggests that there may be both inflation costs and output costs associated with a strong leaning-behavior. 


\section{Introduction}

Since the 2008 global financial crisis, policy-makers in most advanced countries, including Canada, have introduced a set of micro- and macroprudential policies to address financial stability issues. The potential role for monetary policy to deal with financial imbalances, however, remains an area of active study. The Bank of Canada (2011) concluded that there is scope within a flexible inflation targeting framework for monetary policy to play an occasional role in supporting financial stability when there is a solid and credible inflation target. Interactions between monetary policy and financial stability are complex, however, and there is a wide range of views on the extent to which monetary policy should address financial stability concerns in both the academic literature and among policy-makers.

At one end of the spectrum, some authors advocate little or no role for monetary policy to directly address financial stability concerns. They emphasize instead that macroprudential or regulatory tools should be used to address financial imbalances, and monetary policy should focus on price stability or output goals. Other authors call for integration of financial stability goals into monetary policy decisions to allow monetary policy to actively "lean" against financial imbalances. In practice, central banks currently span this range of views as well. While most discuss financial stability concerns, some central banks explicitly include financial stability elements in the monetary policy reaction function. Others maintain a relatively strict separation of the two spheres and base monetary policy action on inflation, output or employment goals only. Recently, Sweden has moved along the spectrum from using monetary policy to actively lean against financial imbalances to making a clear separation of policy goals and applying monetary policy exclusively to attaining its inflation target.

In this paper, we analyze the institutional and operational frameworks of ten central banks from advanced economies and assess the extent to which monetary policy responds to financial stability concerns. Specifically we make two main contributions. First, based on a review of the literature and current policy frameworks at the ten central banks, we construct a time-varying index to measure their orientation to account for financial stability risks in their monetary policy decisions, which we refer to as the "Financial Stability Orientation (FSO)" index. Second, we include our newly constructed FSO index in a modified Taylor rule and estimate its effect on policy interest rates using data from a panel of up to ten central banks for the period from 2000Q1 to 2014Q4. This allows for a heterogeneous response of central banks' monetary policy rates to financial stability risks according to the FSO type of the central bank, where this type is defined based on country-quarter observations of the FSO index.

We find that central bank time observations that obtain a high index value (leaning-type central banks) appear to consider financial stability risks in their interest rate decision while those with low index values (cleaning-type) do not. Our baseline specification suggests that, in the presence of financial stability risks as measured by a strongly positive credit-to-GDP gap, a representative leaning-type central bank's policy rate is about 0.3 percentage points higher than the policy rate of a representative cleaning-type central bank. We also find that the strength of this response increases in the additional presence of a house price boom but not so for the simultaneous occurrence of an equity price boom. 
Our results complement those of Jordà, Schularick and Taylor (2015), who examine the joint occurrence of credit booms and asset price bubbles for up to 17 advanced countries over the last one and a half centuries. The authors find that credit-fueled asset price booms and, in particular, creditfueled house price booms, create substantially worse financial and macroeconomic outcomes than asset price booms that are not fueled by credit. Subsequently, central banks would be expected to react more strongly to joint imbalances in the credit and in the housing market to mitigate potential output losses.

We conclude our study by conducting a preliminary assessment of the impact of leaning behavior on the outcome of macroeconomic variables such as inflation and output. As a part of this exercise, we find that leaning-type central banks respond less, on average, to deviations from the inflation or a potential output target. This suggests that there may be both inflation costs and output costs associated with a strong leaning-behavior.

In the following section we survey the literature on the interaction of monetary policy and financial stability. The third section describes the construction of our financial stability orientation index while the fourth section introduces our empirical specification and describes the underlying data. Section five then presents the results of our empirical analysis and section six discusses their policy implications. Finally, section seven concludes.

\section{Recent Literature}

Before the 2008 global financial crisis, the literature on the interaction between financial stability and monetary policy usually focused on asset prices and asset price volatility. The pre-2008 Jackson Hole consensus concerning the optimal role for monetary policy was quite clear - flexible inflationtargeting provides an effective way to achieve macroeconomic and financial stability (Bernanke and Gertler, 1999, 2001; Gilchrist and Leahy, 2002). If we assume there are efficient capital markets with no financial frictions, asset prices reflect fundamentals and thus should not be a concern for monetary policy. Only if changes in asset prices were due to non-fundamental factors and were expected to affect the real economy should central banks respond, and even then they should only respond indirectly to mitigate the expected effect on inflation and output within a flexible inflationtargeting framework. Given the difficulty in identifying the risks of financial crises, monetary policy should be limited to a cleaning up role if such risks were to materialize.

Since the 2008 global financial crisis, support for the Jackson Hole consensus has weakened, and there is a growing literature examining a potentially more extensive role for monetary policy in addressing financial stability risks. An important part of this research develops conceptual frameworks that better integrate monetary policy and financial stability. Smets (2014), Leeper and Nason (2014) and Loisel (2014) provide overviews of the recent literature. A common approach is to adapt dynamic stochastic general equilibrium (DSGE) models to allow a richer set of financial frictions and heterogeneous agents. The financial frictions cause externalities that result in a buildup of imbalances, which affects the probability of a financial crisis state occurring (e.g., Woodford 2012; and Ajello et al. 2015). More complex interactions between financial frictions, macroprudential policy and monetary policy are also introduced in some models (Brunnermeier and Sannikov 2014; and Angeloni et al. 2014). 
Much of the discussion hinges on the sign of the net effect of an interest rate change on financial stability. How interest rates are expected to affect financial stability outcomes is strongly influenced by both the type of financial frictions considered and the channels through which monetary policy affects financial stability. Aside from the standard interest rate channel, the recent literature usually emphasizes the following monetary policy channels: risk-taking, bank lending and balance sheet. The box in Figure A1 in the Appendix provides a summary of the consequences of an increase in the interest rate along the standard transmission channels. The net effect of an interest rate change on financial stability (and thus the optimal role for monetary policy) depends highly on the relative strength of the transmission channels.

Smets (2014) summarizes the theoretical framework, results and policy recommendations from the recent literature as belonging to three broad views: a modified Jackson Hole consensus view, a leaning against the wind vindicated view, and a financial stability is price stability view.

A substantial part of the literature remains in the vicinity of the old consensus and can be characterized as part of a modified Jackson Hole consensus. It argues for monetary policy focusing exclusively on price stability and promotes the use macroprudential policies to address financial stability concerns. Support for this view comes primarily from the theoretical or DSGE model-based analyses. Under plausible assumptions these studies tend to that find monetary policy is largely ineffective in addressing financial stability concerns (Iacoviello 2005) or that macroprudential policy is more effective (Christensen and Meh 2011; Collard et al. 2012; Kannan, Rabanal and Alasdair 2012; Gelain, Lansing and Mendicino 2013; Alpanda and Zubairy 2014).

Svensson $(2013,2014)$ also calls for monetary policy to focus only on macroeconomic stability. He argues that macroprudential polices are effective tools for targeting financial stability in most countries but that monetary policy is not. He examines the recent case of Sweden and finds that the costs of leaning against the wind are considerably higher than the benefits. He emphasizes the interest rate channel of monetary policy and shows that a higher policy rate can have a negative impact on financial stability because it induces nominal GDP and the price level to fall faster than the reduction of household debt, leading to a higher debt-to-GDP ratio.

The majority of the post-2008 crisis literature, including Smets (2014), supports the leaning against the wind view as long as the price stability target is a clear priority over the financial stability target for monetary policy. Such leaning policies vary widely across studies because different frictions and monetary policy channels are considered. Curdia and Woodford (2009, 2010) introduce a spread between the lending rate and the policy rate. Woodford (2012), Gambacorta and Signoretti (2014) and Ajello et al (2015) incorporate balance-sheet and bank-lending channels with financial frictions into a standard DSGE framework. Borio and Zhu (2012) emphasize the risk-taking channel, which makes financial stability a function of the monetary policy stance. Other authors find that optimal monetary policy should respond differently to shocks depending on the structure of mortgages in the economy (e.g., Rubio 2011; Garriga, Kydland and Šustek 2013) and should operate with a longer inflation-target horizon when the economy faces a house price bubble (Basant Roi and Mendes 2007).

In the leaning view, the central bank's optimal monetary policy framework (e.g., inflation targeting) would not change substantially, but it would likely involve more complex trade-offs. (Smets 2014; Kocherlakota 2014). Specifically, the monetary policy maker would have to stabilize macro-economic target variables (output or inflation gaps) and reduce financial stability risks si- 
multaneously. The optimal monetary policy response in the leaning literature thus depends on the severity and probability of a financial crisis (a function of initial conditions, such as the current position in the financial and business cycles) as well as the relative effectiveness of monetary policy compared with macroprudential policies (a function of the dominant monetary policy transmission channels).

The modified reaction function of the central bank could thus incorporate leaning aspects in different ways. Kocherlakota (2014) considers financial stability risks as adding a variance term to the central bank's loss function. Similarly, Ajello et al (2015) consider different policy-maker loss functions that result from financial crisis risks. A number of authors augment Taylor rules with different financial stability indicator measures. Christiano et al. (2010) suggest adding an indicator of credit growth to the standard Taylor rule. Curdia and Woodford (2009, 2010) compare the standard Taylor rule with their own rule, which includes a measure of credit spreads, and they conclude that the spread-adjusted Taylor rule is superior. Another important result of this view is the importance of a coordinated use of monetary and macroprudential policies (e.g., Angeloni, Faia and Winkler 2014; Rubio and Carrasco-Gallego 2015).

Brunnermeier and Sannikov (2014) are the main proponents of the third view in the literature, which Smets labels financial stability is price stability. They view macroeconomic stability and financial stability as completely intertwined and impossible to distinguish as a result of financial frictions. They see a large portion of financial risks as endogenous to the financial system such that even small negative shocks to the financial system can have substantial and asymmetric macroeconomic effects. They argue that the objective of monetary policy should be to stabilize the financial system, not prices, and to ensure that financial markets and the monetary policy transmission mechanisms function smoothly.

Overall, at the time of writing, there is no consensus in the literature about the role monetary policy should play in supporting financial stability. The existing literature relies heavily on theoretical and model-based analyses, and it shows that small differences in the source of risks, the structure of the economy and the relative effectiveness of macroprudential policy can change the optimal policy mix. The three main views in the literature imply quite different institutional and operational arrangements regarding the separation (integration) of monetary policy and financial regulation or macroprudential policies. These are summarized in Figure A2 in the Appendix. Hence, it will be important to examine a cross-section of countries to learn more about the practical experience of monetary policy that supports financial stability. ${ }^{1}$

\footnotetext{
${ }^{1}$ Two recent papers examine this trade-off as well but focus only on the U.S. case. Using a content analysis for the U.S. Federal Reserve's monetary policy discussions from 1991 to 2013, Oet, Ong and Dooley (2015) find that U.S. monetary policy has evolved over time and includes consideration of additional factors beyond output and inflation. Furthermore, Peek, Rosengren and Tootell (2015) show that after controlling for forecasts of inflation and unemployment, the frequency of terms related to financial instability in Federal Open Market Committee (FOMC) minutes influences monetary policy decisions.
} 


\section{Assessing the Financial Stability Orientation of Central Banks}

\subsection{Major Central Banks' Institutional and Operational Frameworks}

As the literature review has shown, the orientation of central banks toward considering financial stability risks in their monetary policy decision depends on many factors. Here, we provide a brief overview of the different institutional and operational frameworks (loosely corresponding to the determinants outlined in Figure A2 in the Appendix) in ten central banks in major advanced economies, to understand how significant financial stability considerations are to their monetary policy decisions. Table 1 summarizes the components of these frameworks in more detail.

Columns 1 to 3 of the table report the factors used to assess statutory frameworks for financial stability. The first column describes each central bank's legal mandate for promoting financial stability, as set out in its central bank act. While none of the central banks in our sample has a mandate that emphasizes financial stability over price stability, several have an additional or secondary financial stability objective included in their legal mandates. In some cases, these objectives were added or strengthened during our sample period (e.g., the Bank of England, the Reserve Bank of New Zealand and the Swiss National Bank).

In other cases, a central bank's interpretation of its mandate for financial stability may have evolved over time, even if the legislation has not. The second column therefore highlights additional information available on central banks' interpretation of their mandates, communicated both formally (e.g., through official documents) and informally (e.g., through speeches). In general, these communications suggest a growing recognition of how important financial stability is to the achievement of a central bank's macroeconomic objectives. As with the mandates, however, the communications do not suggest the central bank's primary focus is on financial stability. Several communications also indicate that even when the central bank does promote financial stability, monetary policy is not necessarily to be used as the main tool to do so.

The third column notes when each central bank began publishing a financial stability report or financial system review (FSR) analysing financial stability. The preparation of an FSR reflects a central bank's commitment to monitoring and analysing financial stability issues, and its publication represents a channel through which the central bank can be held accountable for tracking these issues. $^{2}$

Columns 4 and 5 report the observable factors used to assess the central banks' financial regulatory authority. How the responsibility for regulating the financial sector is assigned varies considerably across central banks, from those with primary regulatory responsibility (e.g., the Bank of England, the Reserve Bank of New Zealand) to those that do not directly regulate financial institutions but support the work of separate regulatory authorities (e.g., the Bank of Canada, the Reserve Bank of Australia and the Swedish Riksbank). The degree of regulatory responsibility is relevant for discussion of the monetary policy-financial stability nexus because it reflects a central bank's ability to use policies other than the interest rate to respond to emerging financial stability risks. In particular, central banks with greater responsibility for financial sector regulation generally have more direct control over the use of macroprudential policies (MPP), which is further outlined in the final column. Some central banks have primary responsibility for implementing macroprudential

\footnotetext{
${ }^{2}$ Additionally, in some cases the FSR also represents an avenue for the central bank to communicate its recommendations on macroprudential policies to the regulatory authority (e.g., the Swedish Riksbank).
} 
Table 1: Overview of Current Institutional and Regulatory Frameworks in Selected Central Banks

\begin{tabular}{|c|c|c|c|c|c|}
\hline & \multicolumn{3}{|c|}{ Statutory Framework } & \multicolumn{2}{|c|}{ Regulatory Framework } \\
\hline & $\begin{array}{c}\text { Legal mandate } \\
\text { Bold text indicates explicit } \\
\text { financial stability mandates }\end{array}$ & Interpretation of mandate & $\begin{array}{c}\text { FSR } \\
\text { publication }\end{array}$ & $\begin{array}{l}\text { Regulatory responsibility } \\
\text { Classified as having a 'primary', } \\
\text { 'shared' or 'supporting' role }\end{array}$ & $\begin{array}{c}\text { Macro-prudential policy (MPP) } \\
\text { tool kit } \\
\text { e.g. countercyclical buffer (CCB), } \\
\text { loan-to-value (LTV) ratios } \\
\end{array}$ \\
\hline $\begin{array}{l}\text { Reserve } \\
\text { Bank of } \\
\text { Australia } \\
\text { (RBA) }\end{array}$ & $\begin{array}{l}\text { To "ensure that the } \\
\text { monetary and banking } \\
\text { policy of the Bank is directed } \\
\text { to the greatest advantage of } \\
\text { the people of Australia" by } \\
\text { contributing to "(a) the } \\
\text { stability of the currency of } \\
\text { Australia; (b) the } \\
\text { maintenance of full } \\
\text { employment in Australia; } \\
\text { and (c) the economic } \\
\text { prosperity and welfare of the } \\
\text { people of Australia." }\end{array}$ & $\begin{array}{l}\text { The Act has long been } \\
\text { interpreted to imply a } \\
\text { mandate to pursue financial } \\
\text { stability. In } 2010 \text { the RBA } \\
\text { and the Government } \\
\text { recorded their common } \\
\text { understanding of the RBA's } \\
\text { longstanding responsibility } \\
\text { for financial system } \\
\text { stability, as part of the } \\
\text { periodically updated } \\
\text { Statement on the Conduct of } \\
\text { Monetary Policy. }\end{array}$ & $\begin{array}{l}\text { Semi-annual } \\
\text { since 2004Q1 }\end{array}$ & $\begin{array}{l}\text { Supporting: The RBA's } \\
\text { Payments System Board has } \\
\text { regulatory authority for } \\
\text { payments system stability, } \\
\text { while the Australian } \\
\text { Prudential Regulation } \\
\text { Authority (APRA) is } \\
\text { responsible for the } \\
\text { supervision of banks. The } \\
\text { RBA also chairs the Council of } \\
\text { Financial Regulators (a forum } \\
\text { for identifying issues and } \\
\text { trends in the financial } \\
\text { system). }\end{array}$ & $\begin{array}{l}\text { The main tools for } \\
\text { macroprudential supervision in } \\
\text { Australia are only exercisable by } \\
\text { APRA. }\end{array}$ \\
\hline $\begin{array}{l}\text { Bank of } \\
\text { Canada } \\
\text { (BoC) }\end{array}$ & $\begin{array}{l}\text { "...to regulate credit and } \\
\text { currency in the best interests } \\
\text { of the economic life of the } \\
\text { nation, to control and protect } \\
\text { the external value of the } \\
\text { national monetary unit and } \\
\text { to mitigate by its influence } \\
\text { fluctuations in the general } \\
\text { level of production, trade, } \\
\text { prices and employment... } \\
\text { and generally to promote the } \\
\text { economic and financial } \\
\text { welfare of Canada." }\end{array}$ & $\begin{array}{l}\text { Governor Poloz's } 2014 \\
\text { discussion paper } \\
\text { characterised financial } \\
\text { stability issues as a set of } \\
\text { risks that are taken into } \\
\text { account for the monetary } \\
\text { policy decision. }\end{array}$ & $\begin{array}{l}\text { Semi-annual } \\
\text { since 2002Q4 }\end{array}$ & $\begin{array}{l}\text { Supporting: The BoC is } \\
\text { responsible for the oversight } \\
\text { of some financial market } \\
\text { infrastructure and prominent } \\
\text { payment systems. The Office } \\
\text { of the Superintendent of } \\
\text { Financial Institutions (OSFI) } \\
\text { supervises and regulates } \\
\text { federally registered financial } \\
\text { institutions and private } \\
\text { pension plans. }\end{array}$ & $\begin{array}{l}\text { The BoC can provide advice on } \\
\text { MPP, working with OSFI, the } \\
\text { Financial Consumer Agency of } \\
\text { Canada (FCAC), the Canada } \\
\text { Mortgage and Housing } \\
\text { Corporation (CMHC) and the } \\
\text { Department of Finance. }\end{array}$ \\
\hline $\begin{array}{l}\text { European } \\
\text { Central } \\
\text { Bank } \\
(\text { ECB })^{*}\end{array}$ & $\begin{array}{l}\text { "To maintain price stability. } \\
\text { Without prejudice to the } \\
\text { objective of price stability, } \\
\text { the ESCB shall support the } \\
\text { general economic policies in } \\
\text { the Union...The ESCB shall } \\
\text { contribute to the smooth } \\
\text { conduct of policies pursued } \\
\text { by the competent } \\
\text { authorities relating to the } \\
\text { prudential supervision of } \\
\text { credit institutions and the } \\
\text { stability of the financial } \\
\text { system." }\end{array}$ & $\begin{array}{l}\text { The ECB takes a two-pillar } \\
\text { approach to the assessment } \\
\text { of price stability risks: } \\
\text { economic and monetary } \\
\text { analysis. The latter consists } \\
\text { of "a detailed analysis of } \\
\text { monetary and credit } \\
\text { developments with a view } \\
\text { to assessing their } \\
\text { implications for future } \\
\text { inflation and economic } \\
\text { growth." }\end{array}$ & $\begin{array}{l}\text { Semi-annual } \\
\text { since 2004Q4 }\end{array}$ & $\begin{array}{l}\text { Shared with national } \\
\text { authorities. Overall, the ECB } \\
\text { plays a prominent role in } \\
\text { regulation and } \\
\text { macroprudential oversight at } \\
\text { the supranational level (e.g., } \\
\text { through its role in the } \\
\text { European Systemic Risk } \\
\text { Board, an independent EU } \\
\text { body), though national } \\
\text { authorities may still } \\
\text { implement MPP at the } \\
\text { national level. }\end{array}$ & $\begin{array}{l}\text { The ECB's MPP tool kit includes } \\
\text { all MPP instruments laid down } \\
\text { in the Union acts, covering } \\
\text { capital instruments, such as the } \\
\text { CCB, the systemic risk buffer, } \\
\text { capital surcharges of } \\
\text { systemically important } \\
\text { institutions as well as liquidity } \\
\text { instruments, such as the } \\
\text { liquidity coverage ratio. The } \\
\text { ECB can also increase risk } \\
\text { weights on real estate exposures } \\
\text { or set higher limits on large } \\
\text { exposures. }\end{array}$ \\
\hline $\begin{array}{l}\text { Bank of } \\
\text { Japan } \\
\text { (BoJ) }\end{array}$ & $\begin{array}{l}\text { "...to issue banknotes and to } \\
\text { carry out currency and } \\
\text { monetary control. In } \\
\text { addition....to ensure smooth } \\
\text { settlement of funds among } \\
\text { banks and other financial } \\
\text { institutions, thereby } \\
\text { contributing to the } \\
\text { maintenance of stability of } \\
\text { the financial system." }\end{array}$ & $\begin{array}{l}\text { “...monetary policy is } \\
\text { conducted within a } \\
\text { framework in which the } \\
\text { Bank examines various risk } \\
\text { factors, including those } \\
\text { related to financial } \\
\text { imbalances ..." - Takehiro } \\
\text { Sato (Policy Board member), } \\
\text { Nov. } 2014\end{array}$ & $\begin{array}{l}\text { Semi-annual } \\
\text { since } 2005\end{array}$ & $\begin{array}{l}\text { Supporting: The BoJ conducts } \\
\text { on-site examinations and off- } \\
\text { site monitoring of banks. The } \\
\text { Financial Services Agency } \\
\text { (FSA) serves as a regulatory } \\
\text { authority of financial } \\
\text { institutions. In June 2014, the } \\
\text { BoJ and FSA established a } \\
\text { task force to exchange views } \\
\text { on financial stability. }\end{array}$ & $\begin{array}{l}\text { The BoJ supports the FSA in } \\
\text { carrying out macroprudential } \\
\text { policy by monitoring risk and } \\
\text { assessing imbalances in the } \\
\text { financial system (including } \\
\text { through stress testing), with } \\
\text { analysis published in the FSR. }\end{array}$ \\
\hline $\begin{array}{l}\text { Reserve } \\
\text { Bank of } \\
\text { New } \\
\text { Zealand } \\
\text { (RBNZ) }\end{array}$ & $\begin{array}{l}\text { "...to be responsible for (a) } \\
\text { formulating and } \\
\text { implementing monetary } \\
\text { policy..., (b) promoting the } \\
\text { maintenance of a sound and } \\
\text { efficient financial system, } \\
\text { and (c) carrying out other } \\
\text { functions...."( Sept. } 2008 \\
\text { amendment) }\end{array}$ & $\begin{array}{l}\text { An RBNZ policy position } \\
\text { states that the RBNZ will } \\
\text { "take into account the } \\
\text { interactions between } \\
\text { monetary policy and } \\
\text { macroprudential policy } \\
\text { adjustments when reaching } \\
\text { its policy decisions." (May } \\
\text { 2013) }\end{array}$ & $\begin{array}{l}\text { Semi-annual } \\
\text { since October } \\
2004\end{array}$ & $\begin{array}{l}\text { Primary: The RBNZ is } \\
\text { responsible for prudential } \\
\text { regulation and supervision. (It } \\
\text { works with the separate } \\
\text { financial conduct regulator, } \\
\text { the Financial Markets } \\
\text { Authority.) }\end{array}$ & $\begin{array}{l}\text { The RBNZ can employ several } \\
\text { macroprudential tools: } \\
\text { - } C \text { CB } \\
\text { - minimum core funding ratio } \\
\text { - } \text { sectoral capital requirements } \\
\text { - } \text { temporary restrictions on } \\
\text { high-LTV residential } \\
\text { mortgages }\end{array}$ \\
\hline
\end{tabular}


Table 1: Overview of Current Institutional and Regulatory Frameworks in Selected Central Banks (cont'd)

\begin{tabular}{|c|c|c|c|c|c|}
\hline & \multicolumn{3}{|c|}{ Statutory Framework } & \multicolumn{2}{|c|}{ Regulatory Framework } \\
\hline & $\begin{array}{c}\text { Legal mandate } \\
\text { Bold text indicates explicit } \\
\text { financial stability mandates }\end{array}$ & Interpretation of mandate & $\begin{array}{c}\text { FSR } \\
\text { publication }\end{array}$ & $\begin{array}{l}\text { Regulatory responsibility } \\
\text { Classified as having a 'primary', } \\
\text { 'shared' or 'supporting' role }\end{array}$ & $\begin{array}{c}\text { Macro-prudential policy (MPP) } \\
\text { tool kit } \\
\text { e.g. countercyclical buffer }(C C B) \\
\text { loan-to-value (LTV) ratios }\end{array}$ \\
\hline $\begin{array}{l}\text { Norges } \\
\text { Bank }\end{array}$ & $\begin{array}{l}\text { "The Bank shall be an } \\
\text { executive and advisory body } \\
\text { for monetary, credit and } \\
\text { foreign exchange policy. It } \\
\text { shall issue banknotes and } \\
\text { coin, promote an efficient } \\
\text { payment system } \\
\text { domestically as well as vis-à- } \\
\text { vis other countries, and } \\
\text { monitor developments in the } \\
\text { money, credit and foreign } \\
\text { exchange markets." }\end{array}$ & $\begin{array}{l}\text { The March } 2012 \text { MPR } \\
\text { presented adjusted criteria } \\
\text { for an appropriate interest } \\
\text { rate path, and a } \\
\text { corresponding adjusted loss } \\
\text { function, to account for the } \\
\text { potential contribution of } \\
\text { low interest rates to the } \\
\text { build-up on financial } \\
\text { imbalances. }\end{array}$ & $\begin{array}{l}\text { Published in } \\
\text { Economic } \\
\text { Bulletin since } \\
\text { 1997; semi- } \\
\text { annual } \\
\text { separate } \\
\text { report since } \\
\text { 2000Q2; } \\
\text { annual since } \\
2013\end{array}$ & $\begin{array}{l}\text { Shared with the Ministry of } \\
\text { Finance and the financial } \\
\text { supervisory authority. }\end{array}$ & $\begin{array}{l}\text { Norges Bank is responsible for } \\
\text { issuing advice on the CCB level } \\
\text { to the Ministry of Finance. }\end{array}$ \\
\hline $\begin{array}{l}\text { Sveriges } \\
\text { Riksbank }\end{array}$ & $\begin{array}{l}\text { "To maintain price } \\
\text { stability... The Riksbank } \\
\text { shall also promote a safe and } \\
\text { efficient payments system." }\end{array}$ & $\begin{array}{l}\text { In May 2015, Governor } \\
\text { Ingves stated that monetary } \\
\text { policy would only address } \\
\text { financial stability risks if } \\
\text { inflation and inflation } \\
\text { expectations are close to the } \\
\text { target. }\end{array}$ & $\begin{array}{l}\text { Semi-annual } \\
\text { since 1997Q4 }\end{array}$ & $\begin{array}{l}\text { Supporting: Discusses issues } \\
\text { at the Financial Stability } \\
\text { Council with representatives } \\
\text { of the Government, Finans- } \\
\text { inspektionen (FI, the financial } \\
\text { supervisory authority), and } \\
\text { the National Debt Office. }\end{array}$ & $\begin{array}{l}\text { FI has the main responsibility for } \\
\text { macroprudential policy tools. } \\
\text { The Riksbank can make } \\
\text { recommendations to FI } \\
\text { regarding MPP measures in its } \\
\text { FSR. }\end{array}$ \\
\hline $\begin{array}{l}\text { Swiss } \\
\text { National } \\
\text { Bank } \\
\text { (SNB) }\end{array}$ & $\begin{array}{l}\text { To "ensure price stability. In } \\
\text { so doing, it shall take due } \\
\text { account of the development } \\
\text { of the economy. Within this } \\
\text { framework, it shall [among } \\
\text { other tasks] contribute to } \\
\text { the stability of the financial } \\
\text { system." (as of Oct. } 2003 \\
\text { revision) }\end{array}$ & $\begin{array}{l}\text { The National Bank Act was } \\
\text { revised in } 2003 \text { to reflect } \\
\text { that the SNB's core } \\
\text { responsibilities include } \\
\text { (among others) contributing } \\
\text { to the stability of the } \\
\text { financial system. }\end{array}$ & $\begin{array}{l}\text { Published in } \\
\text { Quarterly } \\
\text { Bulletin } \\
\text { 2003Q2; } \\
\text { annual } \\
\text { separate } \\
\text { report since } \\
2004\end{array}$ & $\begin{array}{l}\text { Shared with the Federal } \\
\text { Council (the executive branch } \\
\text { of the government) and } \\
\text { FINMA (the financial market } \\
\text { supervisory authority). }\end{array}$ & $\begin{array}{l}\text { The SNB is responsible for } \\
\text { proposing activation, } \\
\text { modification and deactivation of } \\
\text { the CCB to the Federal Council; } \\
\text { if approved, FINMA supervises } \\
\text { the implementation of the CCB } \\
\text { at the individual bank level. }\end{array}$ \\
\hline $\begin{array}{l}\text { Bank of } \\
\text { England } \\
\text { (BoE) }\end{array}$ & $\begin{array}{l}\text { "To maintain price stability, } \\
\text { and subject to that, to } \\
\text { support the... objectives for } \\
\text { growth and employment." } \\
\text { A financial stability objective } \\
\text { was added in } 2009 \text { and } \\
\text { modified in } 2012 \text { as follows: } \\
\text { "to protect and enhance the } \\
\text { stability of the financial } \\
\text { system of the United } \\
\text { Kingdom." }\end{array}$ & $\begin{array}{l}\text { The August } 2013 \text { MPC } \\
\text { statement included three } \\
\text { "knockout" conditions } \\
\text { under which the policy rate } \\
\text { could have been raised if } \\
\text { the monetary policy stance } \\
\text { was deemed to pose a } \\
\text { significant threat to } \\
\text { financial stability that } \\
\text { cannot be contained by } \\
\text { regulatory actions. }\end{array}$ & $\begin{array}{l}\text { Semi-annual } \\
\text { Financial } \\
\text { Stability } \\
\text { Review } \\
\text { produced } \\
\text { with the } \\
\text { SIB** 1996- } \\
\text { 98, with the } \\
\text { FSA** from } \\
\text { 1998; semi- } \\
\text { annual } \\
\text { Financial } \\
\text { Stability } \\
\text { Report since } \\
\text { 2006Q2 } \\
\end{array}$ & $\begin{array}{l}\text { Primary: The Financial } \\
\text { Services Act (2012) } \\
\text { established the Bank's } \\
\text { Financial Policy Committee } \\
\text { (FPC), a new prudential } \\
\text { regulator as a subsidiary of } \\
\text { the Bank (PRA), and created } \\
\text { new responsibilities for the } \\
\text { supervision of financial } \\
\text { market infrastructure } \\
\text { providers. } \\
\text { (Some institutions are dually } \\
\text { regulated by the PRA and the } \\
\text { Financial Conduct Authority.) }\end{array}$ & $\begin{array}{l}\text { The FPC's tool kit includes } \\
\text { recommendations on } \\
\text { underwriting standards, the } \\
\text { Help to Buy scheme, and the } \\
\text { availability of higher-risk loans, } \\
\text { as well as recommendations or } \\
\text { directions on bank capital } \\
\text { requirements. } \\
\text { In March 2015, new macro- } \\
\text { prudential powers were } \\
\text { conferred to the FPC relating to } \\
\text { LTV and debt-to-income ratios } \\
\text { in mortgage markets, and setting } \\
\text { ratios of total unweighted } \\
\text { liabilities to capital. }\end{array}$ \\
\hline $\begin{array}{l}\text { U.S. } \\
\text { Federal } \\
\text { Reserve }\end{array}$ & $\begin{array}{l}\text { To "promote effectively the } \\
\text { goals of maximum } \\
\text { employment, stable prices, } \\
\text { and moderate long-term } \\
\text { interest rates." }\end{array}$ & $\begin{array}{l}\text { Recent speeches suggest } \\
\text { that the focus of monetary } \\
\text { policy does not deviate from } \\
\text { the dual mandate to address } \\
\text { financial stability concerns } \\
\text { but could do so in the future } \\
\text { if necessary. }\end{array}$ & $\begin{array}{l}\text { Does not } \\
\text { publish an } \\
\text { FSR directly. } \\
\text { Annual } \\
\text { reports are } \\
\text { published by } \\
\text { the Financial } \\
\text { Stability } \\
\text { Oversight } \\
\text { Council } \\
\text { (FSOC) since } \\
\text { 2011 } \\
\end{array}$ & $\begin{array}{l}\text { Shared with the Office of the } \\
\text { Comptroller of the Currency } \\
\text { (OCC), the Federal Deposit } \\
\text { Insurance Corporation } \\
\text { (FDIC), and the Office of } \\
\text { Thrift Supervision (OTS) at } \\
\text { the federal level, and with the } \\
\text { banking departments of the } \\
\text { various states. }\end{array}$ & $\begin{array}{l}\text { The FSOC is the macro- } \\
\text { prudential supervisory agency. } \\
\text { The Federal Reserve Chair is one } \\
\text { of ten voting members. }\end{array}$ \\
\hline
\end{tabular}

*The ECB and EU central banks together perform the tasks of the European System of Central Banks (ESCB).

** Abbreviations stand for the U.K.'s Securities and Investments Board (SIB) and Financial Services Authority (FSA).

Sources: Central bank acts and official documents, government statutes, centraj bank websites, academic and news articles. 
tools that can be used to tackle financial stability concerns directly (e.g., the Bank of England, the Reserve Bank of New Zealand), some share responsibility for MPPs with other authorities (e.g., Norges Bank and the Swiss National Bank issue formal advice on countercyclical capital buffers to the financial regulators), while others play a supporting role to other regulatory bodies in the setting of macroprudential policy (e.g., the Reserve Bank of Australia, the Swedish Riksbank). This categorization is based on the observable arrangements for regulatory and MPP responsibility. However, a central bank could, in practice, have significant influence in discussions with other policy-makers through unobservable channels even if it has no direct regulatory authority in these areas. We cannot account for this in our study.

The above table provides a brief qualitative summary of the possible requirements and intentions central banks have with respect to incorporating financial stability concerns into their monetary policy decisions (which henceforth we refer to as the financial stability orientation of a central bank). Next, we use this information to develop a quantitative index, described in Section 3.2.

\subsection{Financial Stability Orientation Index}

We use the above information to construct an index of financial stability orientation (which we refer to as the FSO index) that categorizes central banks at each time observation as being more associated with the leaning against the wind view (leaning-type central bank) or the Jackson Hole consensus view (cleaning-type central bank). When identifying central banks' FSO, we distinguish this orientation from the actual policy behavior at a specific instance. The index contains three dimensions corresponding to the policy determinants presented in Figure A2 in the Appendix. The first two dimensions reflect the policy frameworks outlined above, and the third reflects a central bank's views on financial stability imbalances relative to other economic developments. The annual averages of each dimension are reported in Table A1 in the Appendix.

Statutory Dimension: The first dimension captures the degree to which a central bank's responsibility for financial stability is established under its legislation, or statutory framework. ${ }^{3}$ Ideally, we would like to identify differences in central banks' legal mandates for promoting financial stability directly. However, the language and emphasis on financial stability varies across central bank mandates, making direct comparison of the legal texts difficult. ${ }^{4}$ Moreover, the way in which central banks implement their mandates can vary across countries and over time, which may not be reflected by differences in the wording of the legal texts. We therefore combine two indicators to construct this dimension: an indicator of whether the central bank act includes an explicit mandate for promoting financial stability and an indicator of whether the central bank publishes an FSR. The first component takes the value of one if maintaining or promoting the stability of the financial system appears in the central bank's mandate (or a closely equivalent term; see Table 1 for more information) as a primary or secondary objective. The second component takes the value of one after a central bank begins independently publishing an FSR, as a proxy of the cen-

\footnotetext{
${ }^{3}$ In Figure A2, it corresponds to Link 2.

${ }^{4}$ For example, the Norges Bank Act assigns Norges Bank authority for credit policy alongside monetary policy, which could be considered as a mandate related to financial stability, though it does not use the term explicitly. The Swiss National Bank Act does explicitly state that the SNB shall "contribute to the stability of the financial system", but lists this among secondary objectives after the primary objective to ensure price stability.
} 
tral banks' operationalization of their financial stability mandate, and a value of zero otherwise. ${ }^{5}$ To combine these components into a single dimension, each is assigned a weight of 0.5 and summed.

Regulatory Dimension: The second dimension represents the degree of responsibility that a central bank has for direct financial regulation and for macroprudential policy (MPP), which may represent a line of defense against financial stability risks. ${ }^{6}$ While MPPs are the most direct policy channel to address financial stability risks, we would not expect a measure of central banks' MPP tool sets to be comparable over the entirety of the sample period because the development of MPPs overall has increased significantly since 2008. However, as outlined in Table 1, a central bank's access to MPP tools is highly related to its degree of responsibility for financial regulation more generally. Therefore, we construct the regulatory dimension of the index to reflect a central bank's responsibility for the direct regulation of financial institutions, which, in recent years, includes setting MPPs as well. ${ }^{7}$ As we construct the FSO index to reflect policy orientation rather than its stance, this classification specifically reflects the available regulatory and MPP tool kit rather than the level of regulation or MPPs in place at any given time. ${ }^{8}$ Given that central banks with the authority to act as a financial regulator or that have access to a strong set of MPPs should be able to address financial imbalances directly and outside of the monetary policy framework, we construct this dimension such that a higher degree of financial regulatory responsibility results in a lower FSO index value. We therefore assign a value of zero when the central bank is sole financial regulator in the economy. We assign a value of 0.5 if it has a shared responsibility and we assign a value of one if it has only a supporting role. We benchmark the assigned values against classifications found in the literature (see Section 9.2 in the Appendix).

View-Based Dimension: The third dimension measures the extent to which central banks express views on the development of financial stability imbalances when communicating their interest rate decisions to the public. ${ }^{9}$ To construct this dimension, we conduct a systematic search of monetary policy decision statements (or equivalent documents) for the ten central banks over the sample period and count the number of financial stability terms cited to explain the factors considered when setting the interest rate. ${ }^{10}$ (See the list of specific search terms used to indicate the presence of financial stability risks in Section 9.2 of the Appendix for details.) To control for varying length and detail of the communications between central banks and across time, and to get a sense of the relative emphasis given to the terms related to financial stability, we normalize

\footnotetext{
${ }^{5}$ The Federal Reserve is a special case. In the U.S., an FSR-type report has been published since $2011 \mathrm{Q} 3$ by the Financial Stability Oversight Council (FSOC), of which the Federal Reserve is a member. To reflect the fact that the central bank is not the sole publisher of the FSR in this case, we assign the FSR indicator a value of 0.5 for the U.S. starting from 2011Q3.

${ }^{6}$ In Figure A2, this dimension corresponds to Link 3.

${ }^{7}$ As noted in the previous section, our assessment of this responsibility is restricted to the observable characteristics of the regulatory and MPP arrangements.

${ }^{8}$ We do not incorporate information about the MPP tool kit of policy-making authorities outside the central bank when constructing this index because it is difficult to assess the degree of influence a central bank may have on the exercise of these tools at any given time.

${ }^{9}$ See relationships summarized by Links 5 to 8 in Figure A2.

${ }^{10}$ To be comparable across countries, our search is limited to the monetary policy decision press releases or equivalent documents (e.g., the opening statement of monetary policy press conferences). While other communications, such as minutes, are also informative, they are not available for all the central banks in our sample and are therefore excluded.
} 
the frequency of financial stability terms by a similar exercise conducted for macroeconomic terms related to inflation and the output gap (see Section 9.2 of the Appendix). The resulting ratio of the references to financial stability to the sum of inflation- and output gap-related terms is then standardized between zero and one for our sample of countries to form our third dimension. ${ }^{11}$ When interpreting this dimension, it is important to note that the inclusion of the financial stability terms in monetary policy communications is not necessarily associated with a particular monetary policy stance. A high ratio of financial stability terms does not necessarily indicate a period of leaning, but rather one where the central bank's views on financial stability were given greater emphasis in its communications about its monetary policy decision.

The overall index value is computed as the unweighted sum of all three dimensions. Since each of the dimensions range between 0 and 1, the aggregated index values range from 0 to 3 . A higher index value is associated with a central bank that is expected to have a greater orientation toward incorporating financial stability concerns in its monetary policy decision (i.e., a leaning-type central bank), and a lower index value is associated with a lower financial stability orientation (i.e., a cleaning-type central bank). The resulting values for the total FSO index are presented in Figure 1.

Figure 1: Total Financial Stability Orientation (FSO) Index, 2000Q1-2014Q4
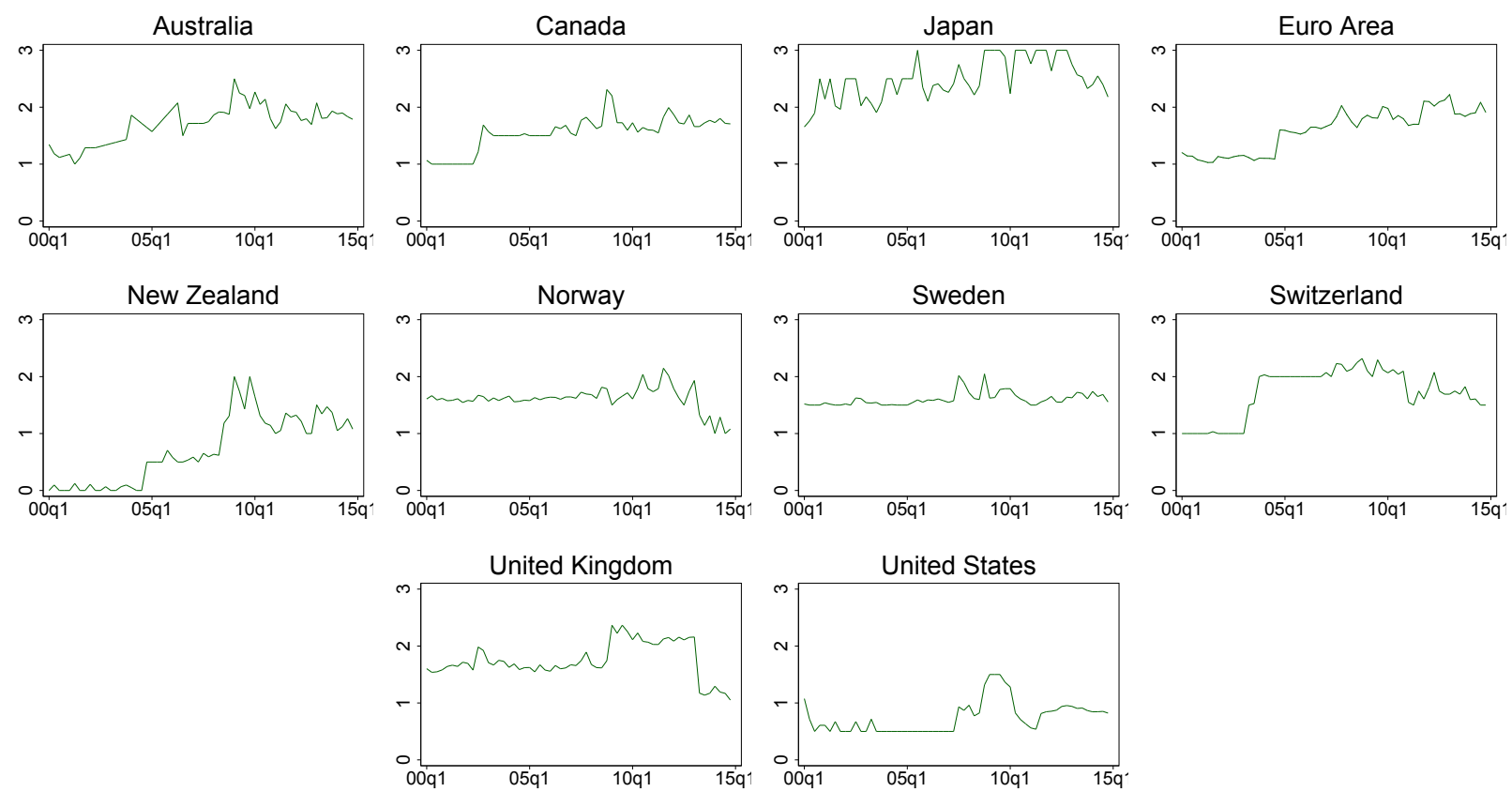

The figure shows that there is considerable variation in the index across countries and over time. We generally observe low index values for the U.S. (except around the 2008 global financial crisis, when discussion of financial terms in policy statements drives up the third dimension of our index) and for New Zealand before 2005. We observe higher index values for Japan, the U.K. (until 2013) and Switzerland (particularly from 2004 to 2010). We also observe a general increase of the

\footnotetext{
${ }^{11}$ To reduce the effect of outliers on the construction of this dimension, we take a $90 \%$ winsorization of the data before computing the standardization.
} 
index values over time that suggests that more central banks have been developing frameworks to account for financial stability considerations in their interest rate decisions. The U.K., however, is an interesting counter-example. While the Bank of England has received more financial stability responsibilities over time, it also has received more regulatory and macroprudential policy tools in the process. This should lower its propensity to rely on the interest rate to achieve financial stability goals. Hence, we observe a downward shift in the U.K. index toward the end of the sample period.

Beyond the three dimensions listed above, there are naturally additional details and idiosyncratic factors related to a central bank's financial stability orientation from which we must abstract. For example, different central banks may have a different degree of influence over other economic policy-makers in their respective countries, and different central bank governors may steer the central bank's operationalization of their authority in different ways. However, much of this information is not publically or consistently available over our sample period, and our FSO index does not account for these details to ensure as much consistency as possible between countries and over time.

\section{Methodology}

\subsection{Taylor Rule Specification}

To assess how financial stability concerns affect monetary policy decisions, we estimate a modified Taylor rule using panel data for the countries of the ten central banks discussed in the previous section. We start with a standard Taylor rule specification and include financial stability terms as well as interaction terms with the output and inflation gaps. ${ }^{12}$ Specifically, we rely on the following baseline specification (Equation (1)):

$$
\begin{aligned}
& i_{i, t}= \mu+\mu_{t}+\mu_{i}+\alpha_{1} \cdot \text { inf_exp_gap }_{i, t}+\beta_{1} \cdot \text { output_gap }_{i, t}+\gamma_{1} \cdot \text { DFSrisk }_{i, t-1} \\
&+\delta \cdot \text { Index }_{i, t}+\gamma_{2} \cdot \text { DFSrisk } \\
& \\
&+\alpha_{2, t-1} \cdot \text { inf_exp_gap }_{i, t} \times \text { Index }_{i, t}+\beta_{2} \cdot \text { output_gap }_{i, t} \times \epsilon_{i, t} \times \text { Index }_{i, t}
\end{aligned}
$$

Where $i_{i, t}$ is the policy rate that varies across countries, $i$, and time, $t$; inf_exp_gap $p_{i, t}$ is a measure of the deviation of inflation expectations from target (the inflation expectations gap); and output_gap $_{i, t}$ is a measure of the output gap. To make use of the panel nature of the data, we also include time fixed effects, $\mu_{t}$, as well as country fixed effects, $\mu_{i}$, whenever we intend to rely on identification along the time dimension, in addition to the general constant $\mu$.

The indicator variable DFSrisk $k_{i, t}$, which takes a value of one in periods of high financial stability risks and zero otherwise, enters the specification with a lag of one quarter. Finally, Index $x_{i, t}$ is the FSO index presented in the previous section. The core of our empirical specification is then the interaction of the financial stability risk measure with the FSO index, DFSrisk ${ }_{i, t-1} \times$ Index $_{i, t}$.

\footnotetext{
${ }^{12}$ Our initial specification corresponds to recent Taylor rule specifications used in the literature. For example, it is similar to the specification without interest rate smoothing that Coibion and Gorodnichenko (2012) estimate for the U.S., with the following two exceptions: (i) For parsimony, we omit the growth term from our baseline specification, though we show that our results are robust to its inclusion in Section 5.3.3. (ii) We replace the forecasts of the output gap used in Coibion and Gorodnichenko (2012) with a contemporaneous estimate of the output gap because it is unclear how expected output dynamics may reflect the interest rate response to financial imbalances.
} 
Its coefficient, $\gamma_{2}$, shows the differential impact of financial stability concerns on the policy rate, depending on the leaner-degree of the central banks in our sample, measured by Index $i, t$. To allow different types of central banks to assign different weights to the inflation or output target, we add interactions of the index with the output gap, output_gap ${ }_{i, t} \times$ Index $_{i, t}$, and with the inflation expectations gap, inf_exp_gap ${ }_{i, t} \times$ Index $_{i, t}$, to the specification.

To evaluate the impact of financial stability on the policy rate, we compute the total marginal effect that is obtained by differentiating Equation (1) with respect to the financial stability risk measure:

$$
\frac{\partial i_{i, t}}{\partial D F \operatorname{Srisk}_{i, t}}=\gamma_{1}+\gamma_{2} \times \operatorname{Index}_{i, t}
$$

The total marginal effect consists of the sum of coefficient $\gamma_{1}$ plus the product of coefficient $\gamma_{2}$ and Index $x_{i, t}$ and is therefore dependent on the value of the FSO index. With a low index value (i.e., a cleaning type central bank), we would expect a small or insignificant effect of financial stability risks on the policy rate. With a high index value (i.e., a leaning type), however, we would expect overall a positive and significant effect because those central banks are more likely to take financial stability risks into account when setting their interest rate.

We estimate the model using quarterly data that covers up to ten of the largest advanced economies (i.e., Australia, Canada, the euro area, New Zealand, Norway, Sweden, Switzerland, the U.K., the U.S. and, in selected specifications, Japan) over the period from 2000Q1 to 2014Q4. However, three countries contain missing data in the beginning of this period.

First, the euro area does not have data on our measure of inflation expectations until $2002 \mathrm{Q} 4$. Second, the Bank of England's inflation target was defined in terms of the retail price index less mortgage interest payments (RPIX) inflation until 2003Q4 (after which it switched to the consumer price index), and we therefore exclude the quarters during which the target was not comparable with the rest of the period. And third, during the early 2000s, monetary policy in Norway was heavily driven by idiosyncratic factors, such as the oil price, the exchange rate and an increasing interest rate differential with major European trading partners. While these factors play an important role for monetary policy decisions in small open economies or commodity exporting countries in general, the combination of factors in Norway at this time was exceptional. While domestic inflation increased by 4 percentage points within one year, peaking at 4.5 percent in 2003Q1, the Norwegian central bank started lowering its policy rate aggressively in $2002 \mathrm{Q} 4 .^{13}$ To avoid introducing substantial errors in the panel estimates as a result of this experience, we exclude Norway until 2003Q1 from our sample, after which inflation rates started to fall. ${ }^{14}$ For most of the analysis, we also treat

\footnotetext{
${ }^{13}$ Norges Bank lowered the policy rate from 7.00 percent in 2002Q3 to 1.75 percent in 2004Q1.

${ }^{14}$ In Section 5.3.3, we present evidence on alternative specifications that avoid the three exclusions. In the first case, we replace inflation expectations with CPI inflation, for which euro area data is present over the entire sample period. In the second and third cases, we introduce a set of two indicator variables that take on the value of one in case of the two affected countries and periods (and the value of zero otherwise), while keeping all observations in the sample. In both alternatives, the results of our empirical analysis remain unchanged. However, especially in the case of the U.K. and Norway, a clean exclusion from the sample is preferable given that the frequent use of interaction terms in our empirical analysis would require the additional interaction of various variables with the indicator variables to account for slope differences arising from the above mentioned irregularities.
} 
Japan differently. With very low inflation and interest rates, two changes in the inflation target, as well as the absence of financial stability risks according to our currently used definition over the sample period, Japan is largely an outlier in the sample. We present results for the baseline and other key specifications both including and excluding Japan, but we estimate the remaining specifications without Japan. As shown later, we find that the inclusion of Japan does affect some of the estimated coefficients without overturning our results.

\subsection{Data Definitions and Identifying Periods of Financial Stability Risk}

Here we briefly describe the data and variables used in the empirical analysis. Table A2 of the Appendix provides summary statistics for the below variables included in our baseline specification.

Policy Interest Rates: The left-hand side variable used in all of our Taylor Rule estimations is the central bank's official policy interest rate in percentage terms.

Inflation Gap: The Taylor rule specification includes real-time inflation expectations, which stresses the forward-looking element in the monetary policy decision. We construct expectations as a weighted average of next-year inflation forecasts reported by Consensus Economics, taking quarterly averages of the monthly forecasts. ${ }^{15}$ We include all inflation measures as gaps that represent the difference between inflation (expectations) and the explicit or implicit inflation target at each point in time. ${ }^{16}$

Output Gap: Given the lack of quarterly data on output gaps for our sample of countries, we construct a measure of the output gap. ${ }^{17}$ Our gap measure is constructed as the cyclical component of seasonally adjusted quarterly real GDP (extracted using a two-sided Hodrick-Prescott (HP) filter with a smoothing parameter of $\lambda=1600$ ) as a percentage of actual GDP. ${ }^{18}$

Financial Stability Risk Indicator: When constructing our measures of financial stability risk (also referred to as "boom" measures), we closely follow a large body of work on defining financial cycles and identifying periods of heightened financial instability that has been carried out by the Bank for International Settlements (e.g., BIS 2010; Drehmann et al. 2010; Drehmann, Borio and Tsatsaronis 2011). ${ }^{19}$

\footnotetext{
${ }^{15}$ In Section 5.3.3, we replace the inflation expectations measure by contemporaneous year-on-year headline CPI inflation rates from the Organisation for Economic Co-operation and Development (OECD) that are consistently defined across countries as well as by a set of country-specific measures of headline inflation from national sources.

${ }^{16}$ When applicable, the inflation target is defined as the midpoint of the target range or the upper bound of an asymmetric target. This gives us an inflation target of 2 percent for all observations, with the exception of Norway and Australia (with inflation targets of 2.5 percent), New Zealand until 2002Q3 (1.5 percent) and Japan (0 percent until 2011Q4 and 1 percent from then until 2012Q4).

${ }^{17}$ Orphanides (2001) argues in favor of using a real time measure of the output gap. However, using a measure of output gap expectations, for example, might be problematic in the context of this paper because these could include assumptions about the central bank's future policy response. In particular, assumptions about the effect of its response to financial stability risks on the expected output gap may affect our identification of the link between financial stability risk and the policy rate.

${ }^{18}$ We present the results from alternative measures of economic slack, such as an output gap obtained using a one-sided HP filter and an interpolated output gap measure from the OECD in Section 5.3.3.

${ }^{19}$ These measures are constructed to identify periods where the financial stability variable is a certain amount above
} 


\section{Identifying Financial Cycles}

The BIS approach to identifying financial cycles has three distinctive characteristics. First, the BIS advocates the close monitoring of credit and asset prices in the economy. Credit is measured as the outstanding amount of loans, debt securities, currency and deposits held by the private nonfinancial sector at the end of a given quarter, and it enters the analysis as a ratio to GDP. ${ }^{20}$ Asset prices are represented by house and equity price indexes and enter the analysis in real terms. ${ }^{21}$ Second, the BIS promotes the idea that financial cycles are distinct from business cycles and have an average duration of 16 to 20 years instead of the usual 5 to 6 years in the case of business cycles. This has important consequences for the empirical identification of financial stability risks. Assuming that financial cycles are longer, it is important to estimate the trend component of a financial variable on sufficient amounts of data. If the sample period is too short, for example, it is not possible to distinguish between cyclical movements and the trend itself, especially in periods of strongly increasing or decreasing values, whereas in a short sample the trend would simply mimic the cyclical component. ${ }^{22}$ Further, under such circumstances, the trend itself needs to be calculated differently. The BIS therefore recommends using an HP filter with a lambda value of 400,000. This is much higher than in the case of business cycles, where the typical value for quarterly data is 1,600. As a result of both choices, the trend is flatter, and the recent increases in financial variables are located above the trend. Third, the BIS recommends using the information set of policy-makers to identify financial cycles. This means calculating the gap in real time, with a one-sided HP filter instead of a two-sided one. To initialize the filter, we use a two-sided HP filter to calculate the trend of each variable from 1975Q1 to 1984Q4, after which we use the one-sided HP filter to calculate the trend from 1985Q1 to the end of the sample in 2014Q4. ${ }^{23}$ Following the above steps, we obtain the cyclical component of the financial stability variable.

\section{Identifying Periods of Financial Stability Risk}

There is little evidence that monetary policy-makers would respond to financial conditions in a linear way. Instead, even for leaning-type central banks, it is more likely that small deviations of financial variables from their trends will be noted but not addressed, and central banks are only likely to respond to major increases in financial stability risks by using the policy rate. Therefore, instead

its trend, i.e., when its cyclical component is greater than a given threshold value. Recent papers with alternative procedures for identifying periods of financial booms and busts include Jordà, Schularick and Taylor (2015) and Bauer (2015).

${ }^{20}$ Credit data are available from the BIS from 1999Q1 for the euro area and from 1975 for all other countries, except New Zealand. The euro area data are extended back to 1975 using the growth rates of the GDP-weighted average of credit-to-GDP ratios in Germany, France, Spain and Italy. Credit data for New Zealand are available from 1988Q1 from the Reserve Bank of New Zealand. As a result of a change in the RBNZ's Standard Statistical Return survey, these data are not directly comparable with the previous credit series available from 1960Q1 to 1986Q4. The growth rates of Australia's credit-to-GDP ratio are therefore used to extend New Zealand's data back to 1975.

${ }^{21}$ The real house price index for the euro area was obtained from the BIS from 1980 and from the Federal Reserve Bank of Dallas for all other countries from 1975. The equity price indexes were obtained from Bloomberg and Morgan Stanley Capital International (MSCI) and converted to real terms using the CPI. For the euro area, the equity price index is the Euro Stoxx 50 index from 1987Q1 until the end of the sample and is extended back to 1975 using the growth rates of the GDP-weighted average of MSCI Share Price Indexes for Germany, France, Italy and Spain.

${ }^{22}$ In this case, even though a financial variable could be at record levels, there would be no indication of above-trend behavior.

${ }^{23}$ After using the earlier values to compute the trend and cyclical components of the variables, we only consider the period from 2000Q1 to 2014Q4 in our empirical analysis. 
of working with the cyclical component directly, we choose to construct a set of indicator variables that seeks to identify periods of high financial stability risks based on the cyclical component. These indicator variables take on the value of one when the cyclical component is above a pre-defined threshold and zero otherwise. To avoid frequent switches in the indicator variable, we further smooth the cyclical component of all three financial variables using a backward-looking filter that uses information from the contemporaneous observation and a number of lagged observations.

For the slower moving variables, such as credit and the real house price series, we smooth the cyclical component using eight lags, which corresponds to a two-year horizon. In Section 5.3.5, we also present the results of shorter lags, such as the contemporaneous value plus the values of the last six or four quarters. However, the smaller the number of included lags is, the more often the indicator variable switches between 0 and 1 . While this might be a desirable piece of information in some applications (e.g., early warning models), it is less likely to successfully classify periods of heightened financial stability risk as an input into a monetary policy decision. In practice, central banks usually change their policy rates gradually over time, so it is unlikely for rates to respond to high frequency movements in the financial stability risk indicator. Instead, it is preferable to have an indicator that produces clearly distinct episodes of zeros and ones. Given that equity prices move faster than the credit-to-GDP ratio or real house prices, we use a lag of four quarters for their associated backward-looking smoothing procedure. ${ }^{24}$

We then take the smoothed cyclical component of the credit variable as a gap measure, and use this to construct a financial stability risk indicator as described above, according to a set of threshold values (cut-offs) used by the BIS. We conduct the same procedure to smooth the cyclical component of real house and equity prices after normalizing the cyclical component by the trend.

The BIS presents a range of cut-off values for the credit-to-GDP gap from 2 to 14 percentage points (in steps of two, e.g., 4, 6, 8), from 6 to 12 percentage points for the real house price gap (again in steps of two), and from 5 to 25 percentage points for the real equity gap (in steps of five). We largely follow these suggested threshold values but adjust the range of cut-off values somewhat to allow a reasonable number of countries to enter the sample with at least one boom identified. Further, it is possible that central banks respond to combinations of financial stability risks and not only to specific risks in just one of the above measures. One of the core arguments of the leaning against the wind view is that the use of (sector-specific) macroprudential policies is most adequate for specific risks, central banks should use their interest rate to tackle financial stability concerns whenever the imbalances are widespread in the economy. This also corresponds to the findings of Jordà, Schularick and Taylor (2015), who advocate a higher crisis probability when booms appear in credit and asset prices at the same time. We therefore construct two joint indicator variables that take the value of one if both of the variable-specific indicators are one and zero otherwise. The first joint indicator takes the value of one if credit and real house prices have a positive gap at the same time, and the second indicates when credit and real equity prices have a positive gap in both variables at the same time. ${ }^{25}$ Given the more strict definition of the joint measure, we consider the cut-off values for housing and equity prices at the lower end. ${ }^{26}$

\footnotetext{
${ }^{24}$ The results are similar when the same eight-quarter smoothing procedure is used; however, some of the equity price booms are dated very late in this case.

${ }^{25}$ In the case of combinations, we apply the smaller number of lags used to smooth both variables.

${ }^{26}$ There is also a peculiarity in the definition of the equity price measure in our sample. The cut-off values by the BIS are defined over a long time period. Historically, the cut-off values of a 25-percentage-point gap in equity prices
} 
Figure 2: Financial Stability Indicator of Booms in the Credit Market (defined by an 8 percentage point cut-off), 2000Q1-2014Q4
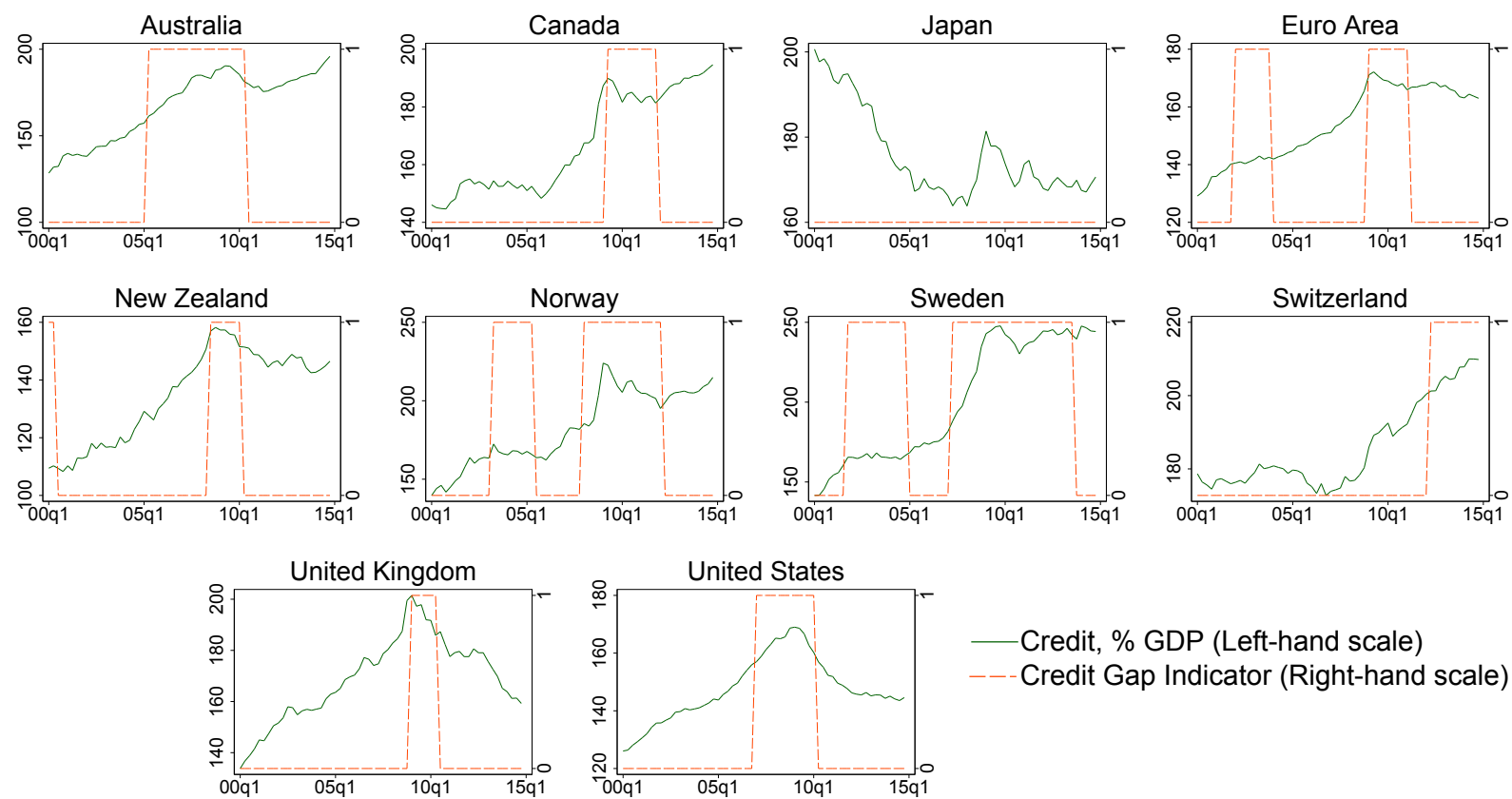

Credit, \% GDP (Left-hand scale)

---Credit Gap Indicator (Right-hand scale)

Figure 3: Financial Stability Indicator of Joint Booms in the Credit and Housing Markets (defined by 4 percentage point cut-offs), 2000Q1-2014Q4
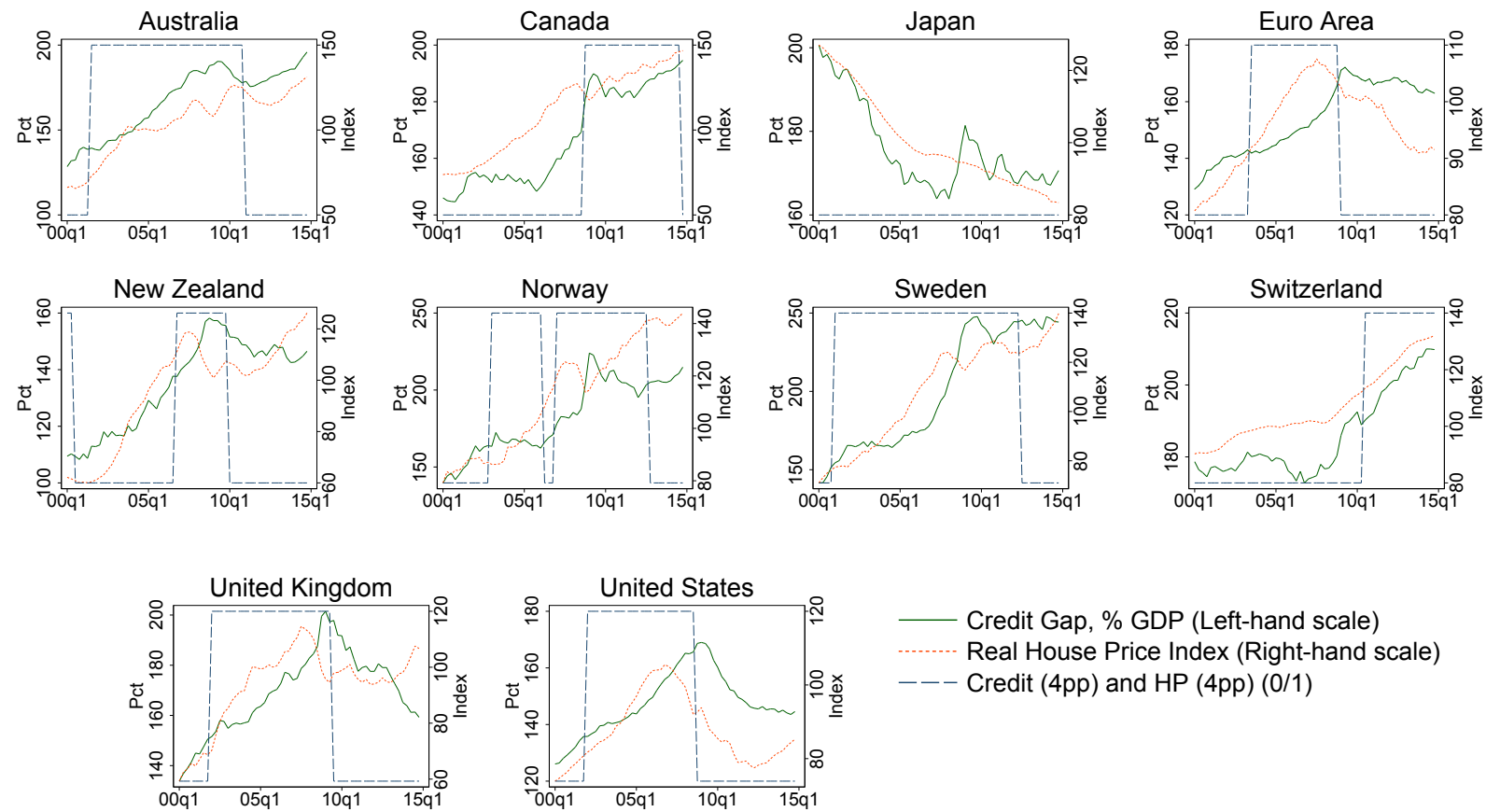

_ Credit Gap, \% GDP (Left-hand scale)

.......- Real House Price Index (Right-hand scale)

--- Credit (4pp) and HP (4pp) (0/1)

have existed. However, given the presence of the dot-com bubble and the 2008 global financial crisis in our sample, recent equity price dynamics are around or even below the trend in most advanced countries, and are even more so when considered in real terms. 
Figure 2 on page 17 presents the indicator variable for a gap of 8 percentage points in the credit-to-GDP ratio for all our sample countries, which is also the measure we use in our baseline specification. According to this measure, all countries except Japan experience at least one credit boom over the sample period from 2000Q1 to 2014Q4. Norway experienced a credit boom for nearly half of the period, and in Sweden the indicator suggests that more than half of the sample period experienced a boom. In addition, Figure 3 presents an example of a joint indicator variable that takes on the value of one when both the credit-to-GDP gap and the real house price gap are higher than 4 percentage points. ${ }^{27}$ As with the credit indicator, this composite measure indicates that all countries except Japan experience at least one such joint boom over the sample period. It suggests that more than half of the sample period experienced a financial stability boom in Sweden, Australia and Norway.

\section{$5 \quad$ Estimation Results}

\subsection{The Heterogeneous Response of Central Banks to Financial Stability Risks}

In this section, we present the results from estimating the baseline specification in our sample of central banks from up to ten countries over the period from 2000Q1 to 2014Q4. The panel yields usually between 500 and 560 observations, depending on whether or not Japan is included. Initially, Japan is excluded from the sample. In Table 2, we establish the corresponding baseline specification for nine countries step by step.

Specification (1) presents the coefficients of the two standard determinants of the Taylor rule, the deviation of inflation (expectations) from target, also referred to as the inflation expectations gap, Inflation Exp. Gap, and a measure of the output gap, Output Gap. Both coefficients have the expected positive signs. An increase in either the inflation expectations gap or the output gap leads to an increase in the policy rate.

In specifications (2) and (3), we include a measure of financial stability risk in the previous specification. As explained in the previous section, we measure financial stability risk using an indicator variable that takes on the value of one when financial imbalances are present and a value of zero otherwise. The financial stability risk measure used in Table 2 is one of several measures employed in this paper and indicates the presence of a large and positive credit gap, i.e. the indicator variable takes on the value of one when the credit gap is greater than 8 percentage points of GDP, and zero otherwise. The indicator variable is lagged by one period and denoted as L1.Credit Gap (8pp) in the table. As shown in specifications (2) and (3), the impact of financial stability risks on the policy rate in our sample of nine central banks is positive although only significant in specification (2), suggesting that the central banks in our sample countries do, on average, respond with higher interest rates to this specific measure of financial stability risk. However, since at this stage we do not distinguish between different types of central banks, the average effect is not very informative. Both specifications (2) and (3) contain time fixed effects to filter out factors that affect all countries identically e.g., the financial crisis, global commodity price shocks, quantitative easing

\footnotetext{
${ }^{27}$ The joint measure presented in Figure 3 is based on individual boom measures constructed using lower cut-offs than the individual boom measure in Figure 2 because the presence of joint risks across both credit and housing markets may capture the attention of the central bank even at lower deviations from trend.
} 
Table 2: Taylor Rule Estimation with a Financial Stability Indicator of Credit Gaps, 2000Q1-2014Q4

\begin{tabular}{|c|c|c|c|c|c|c|c|c|c|}
\hline & \multicolumn{7}{|c|}{ Excluding Japan } & \multicolumn{2}{|c|}{ Including Japan } \\
\hline & (1) & $(2)$ & (3) & (4) & $(5)$ & (6) & $(7)$ & (8) & (9) \\
\hline Output Gap & $\begin{array}{c}0.400^{* * *} \\
(0.00)\end{array}$ & $\begin{array}{l}0.121 \\
(0.10)\end{array}$ & $\begin{array}{c}0.179^{* * *} \\
(0.00)\end{array}$ & $\begin{array}{l}0.094 \\
(0.17)\end{array}$ & $\begin{array}{c}0.153^{* * *} \\
(0.00)\end{array}$ & $\begin{array}{c}0.504^{* * *} \\
(0.00)\end{array}$ & $\begin{array}{c}0.679^{* * *} \\
(0.00)\end{array}$ & $\begin{array}{c}0.521^{* * *} \\
(0.00)\end{array}$ & $\begin{array}{c}0.687^{* * *} \\
(0.00)\end{array}$ \\
\hline Inflation Gap & $\begin{array}{c}1.183^{* * *} \\
(0.00)\end{array}$ & $\begin{array}{c}1.104^{* * *} \\
(0.00)\end{array}$ & $\begin{array}{l}0.123 \\
(0.23)\end{array}$ & $\begin{array}{c}0.989^{* * *} \\
(0.00)\end{array}$ & $\begin{array}{l}0.120 \\
(0.23)\end{array}$ & $\begin{array}{c}2.250^{* * *} \\
(0.00)\end{array}$ & $\begin{array}{c}0.821^{* * *} \\
(0.00)\end{array}$ & $\begin{array}{c}2.055^{* * *} \\
(0.00)\end{array}$ & $\begin{array}{c}1.215^{* * *} \\
(0.00)\end{array}$ \\
\hline L1.Credit Gap (8pp) & & $\begin{array}{c}0.375^{* * *} \\
(0.00)\end{array}$ & $\begin{array}{l}0.155 \\
(0.12)\end{array}$ & $\begin{array}{c}-1.875^{* * *} \\
(0.00)\end{array}$ & $\begin{array}{c}-0.867^{* *} \\
(0.02)\end{array}$ & $\begin{array}{c}-2.017^{* * *} \\
(0.00)\end{array}$ & $\begin{array}{c}-0.971^{* *} \\
(0.03)\end{array}$ & $\begin{array}{c}-2.540^{* * *} \\
(0.00)\end{array}$ & $\begin{array}{c}-0.794^{*} \\
(0.07)\end{array}$ \\
\hline FSO Index & & & & $\begin{array}{c}-0.632^{* * *} \\
(0.00)\end{array}$ & $\begin{array}{c}-0.611^{* * *} \\
(0.00)\end{array}$ & $\begin{array}{c}-0.375^{* *} \\
(0.02)\end{array}$ & $\begin{array}{c}-0.465^{* * *} \\
(0.00)\end{array}$ & $\begin{array}{c}-1.163^{* * *} \\
(0.00)\end{array}$ & $\begin{array}{c}-0.365^{* *} \\
(0.01)\end{array}$ \\
\hline L1.Credit Gap x Index & & & & $\begin{array}{c}1.452^{* * *} \\
(0.00)\end{array}$ & $\begin{array}{c}0.654^{* * *} \\
(0.00)\end{array}$ & $\begin{array}{c}1.565^{* * *} \\
(0.00)\end{array}$ & $\begin{array}{c}0.708^{* * *} \\
(0.01)\end{array}$ & $\begin{array}{c}2.025^{* * *} \\
(0.00)\end{array}$ & $\begin{array}{c}0.570^{* *} \\
(0.03)\end{array}$ \\
\hline O.Gap x Index & & & & & & $\begin{array}{c}-0.239^{* *} \\
(0.02)\end{array}$ & $\begin{array}{c}-0.337^{* * *} \\
(0.00)\end{array}$ & $\begin{array}{c}-0.247^{* * *} \\
(0.00)\end{array}$ & $\begin{array}{c}-0.313^{* * *} \\
(0.00)\end{array}$ \\
\hline Inf. Gap x Index & & & & & & $\begin{array}{c}-0.790^{* * *} \\
(0.00)\end{array}$ & $\begin{array}{c}-0.481^{* * *} \\
(0.00)\end{array}$ & $\begin{array}{c}-0.740^{* * *} \\
(0.00)\end{array}$ & $\begin{array}{c}-0.694^{* * *} \\
(0.00)\end{array}$ \\
\hline Time Fixed Effects & No & Yes & Yes & Yes & Yes & Yes & Yes & Yes & Yes \\
\hline Country Fixed Effects & No & No & Yes & No & Yes & No & Yes & No & Yes \\
\hline $\mathrm{R} 2$ & 0.35 & 0.63 & 0.87 & 0.66 & 0.88 & 0.68 & 0.89 & 0.64 & 0.88 \\
\hline $\mathrm{N}$ & 500 & 500 & 500 & 500 & 500 & 500 & 500 & 560 & 560 \\
\hline Countries & 9 & 9 & 9 & 9 & 9 & 9 & 9 & 10 & 10 \\
\hline Total FS Effect, 25 pctl & & & & -0.276 & -0.147 & -0.292 & -0.191 & -0.164 & -0.125 \\
\hline p-value & & & & 0.25 & 0.32 & 0.24 & 0.26 & 0.49 & 0.43 \\
\hline Total FS Effect, 75 pctl & & & & $0.720 * * *$ & $0.302^{* * *}$ & $0.782^{* * *}$ & $0.295^{* * *}$ & $1.331^{* * *}$ & $0.296^{* *}$ \\
\hline $\mathrm{p}$-value & & & & 0.00 & 0.00 & 0.00 & 0.00 & 0.00 & 0.01 \\
\hline
\end{tabular}

The financial stability indicator is calculated from an 8-percentage-point (pp) threshold of the credit gap, smoothed over 8 lags.

All specifications include a constant. p-values in parentheses. ${ }^{*} p<0.10,{ }^{* *} p<0.05,{ }^{* * *} p<0.01$ 
(QE) or tapering announcements by the Federal Reserve.

In addition, specification (3) contains country fixed effects that account for alternative explanations of interest rate levels, such as country-specific but time-constant factors (e.g., different interpretation of inflation targets, different weights on the output target), and thus allows us to exploit the variation over time. As a side product of the inclusion of time fixed effects, the output gap term becomes temporarily insignificant in specification (2), which can be explained by the high synchronization of business cycles across countries and the fact that not all central banks target output or activity gaps. Similarly, in specification (3), after the inclusion of country fixed effects the expected inflation gap coefficient becomes temporarily insignificant since a constant inflation target can be hard to distinguish from a country fixed effect. ${ }^{28}$

In specifications (4) and (5), we add our FSO index by including it as an individual term, FSO Index, and as an interaction with the financial stability risk indicator variable, DFSrisk $\times$ FSO Index. Specification (5) differs from specification (4) because of the additional inclusion of country fixed effects, which again change the identification from cross-sectional variation to time variation. In both cases, the coefficient on the interaction term with the financial stability risk variable and our FSO index, L1.Credit Gap $\times$ Index, is positive and highly significant. This suggests that leaningtype central banks appear to have a significantly higher policy rate than cleaning-type central banks in times of elevated financial stability risks. There is a substantial difference between the version with and without country fixed effects. In specification (4), which has no country fixed effects, the coefficient on the interaction term amounts to 1.452, while the coefficient estimate in specification (5), with country fixed effects, is only 0.654. This suggests that the inclusion of country fixed effects is important and the effect of financial stability risks on the interest rate might be overstated in the estimation with pooled data.

The two "Total FS Effect" lines at the bottom of the table compare the total marginal effect of the financial stability risk variable on the interest rate for a representative cleaning-type and a representative leaning-type central bank, respectively. We identify the two central-bank types as the $25^{\text {th }}$ and $75^{\text {th }}$ percentile of the distribution of our FSO index (i.e., based on all country-time observations of the index). ${ }^{29}$ Using the estimated coefficients in specification (5) as an example, a representative leaning-type central bank in the sample obtains an index value of 1.79 and thus experiences a total marginal effect of 0.30 (the total marginal effect can be computed by adding the financial stability risk coefficient, L1.Credit Gap (8pp), and the product of the coefficient of the interaction term, L1.Credit Gap $\times$ Index, with the respective index value) and thus will, ceteris paribus, increase its policy rate in times of credit-related financial stability concerns by approximately 0.30 percentage points. Taking the estimated coefficients of specification (5) as an example again, a representative cleaning-type central bank (that obtains an index value of 1.10), will not change the interest rate in such a case. The joint significance of the linear combination is assessed using a $t$-test (where the respective $p$-value is reported below the coefficient estimate).

\footnotetext{
${ }^{28}$ We allow different types of central banks to have different coefficients through the addition of interaction terms, so the significance of the output gap and the inflation expectations gap coefficient will return. In cases where the measure of financial stability risk is excluded from the specification and only time and/or country fixed effects are included, the coefficients of the two macro variables show the same patterns of significance as in specifications (2) and (3).

${ }^{29}$ The $25^{\text {th }}$ and $75^{\text {th }}$ percentile values have been chosen conservatively and indicate the marginal effects for representative country-time observations. However, other countries or time periods might be associated with higher or lower index values and thus we would expect stronger differences in their marginal effects in such cases.
} 
So far, we have constrained the response of central banks to changes in the output and the inflation expectation gaps to be identical across leaning- and cleaning-types. However, since leaning-type central banks have, on average, higher interest rates in times of elevated financial stability risks, we would expect their response to output and inflation dynamics to be different from cleaning-type central banks. Specifications (6) and (7) therefore allow for a different weighting of the output gap and the inflation expectation gap coefficients across leaning- and cleaning-type central banks. Both specifications contain time fixed effects, and specification (7) additionally contains country fixed effects. Specification (7) corresponds exactly to Equation (1) in Section 4.1, and thus represents our baseline specification. According to the negative and highly significant coefficients on the interaction terms between the FSO index and the output gap or the inflation expectations gap, our estimates suggest that a leaning-type central bank will indeed respond less aggressively to deviations in the two macro variables. This is anticipated to some extent because leaning-type central banks will place more weight on the mitigation of financial stability risks, which is confirmed by the positive and highly significant interaction of the financial stability risk variable and the FSO index. It amounts to 1.565 in the case when only time fixed effects are included in specification (6) and to 0.708 in the case when both time and country fixed effects are included in specification (7). Again, the analysis of the total marginal effects suggests that a representative cleaning-type central bank increases policy rates in light of financial stability concerns by 0.295 percentage points in a model with country fixed effects (and by 0.782 in a model without country fixed effects), whereas a representative cleaning-type central bank does not change policy rates in such case. Since including country fixed effects turns out to be important in the fully interacted specification, we again put more emphasis on the outcome of specification (7) relative to specification (6). Therefore, in the remainder of the paper, we only refer to specification (7) as our baseline specification.

In addition to presenting the total marginal effect for two specific values of our FSO index, we also plot the marginal effect for every possible value of the index. Figure 4 plots the total marginal effect of financial stability risks on the policy rate, depending on the sample values of the FSO index (which range from 0 to 2.5 in the case without Japan) for the coefficients of the baseline specification (i.e., specification (7)). With a positive slope, the marginal effect is slightly below zero or insignificant for a low index value (i.e., for cleaning-type central banks) $)^{30}$ and are positive and significant for higher index values (i.e., cleaning-type central banks). The threshold value of the FSO index where central banks start to take financial stability risks in their monetary policy decision into account is slightly above 1.5. Our estimates imply that an extreme leaningtype central bank with a hypothetical index value of 2.5 , for example, would increase interest rates in times of financial stability risks by about 0.75 percentage points. However, the dashed line in the background indicates the sample distribution of our FSO index and shows that these extreme values are very rare. The mass of the distribution of country-quarter observations in our sample lies between FSO index values of 1.00 and 2.25, indicating that most are of a moderate leaning-type with policy rate increases of up to 0.3 percentage points in times of credit booms.

\footnotetext{
${ }^{30}$ The bands around the slope coefficient indicate a $90 \%$ confidence interval.
} 
Figure 4: Marginal Effect of Credit Gap Indicator (8pp) on Policy Rate at Different FSO Index Values; Estimated Over 2000Q1-2014Q4 with Country Effects

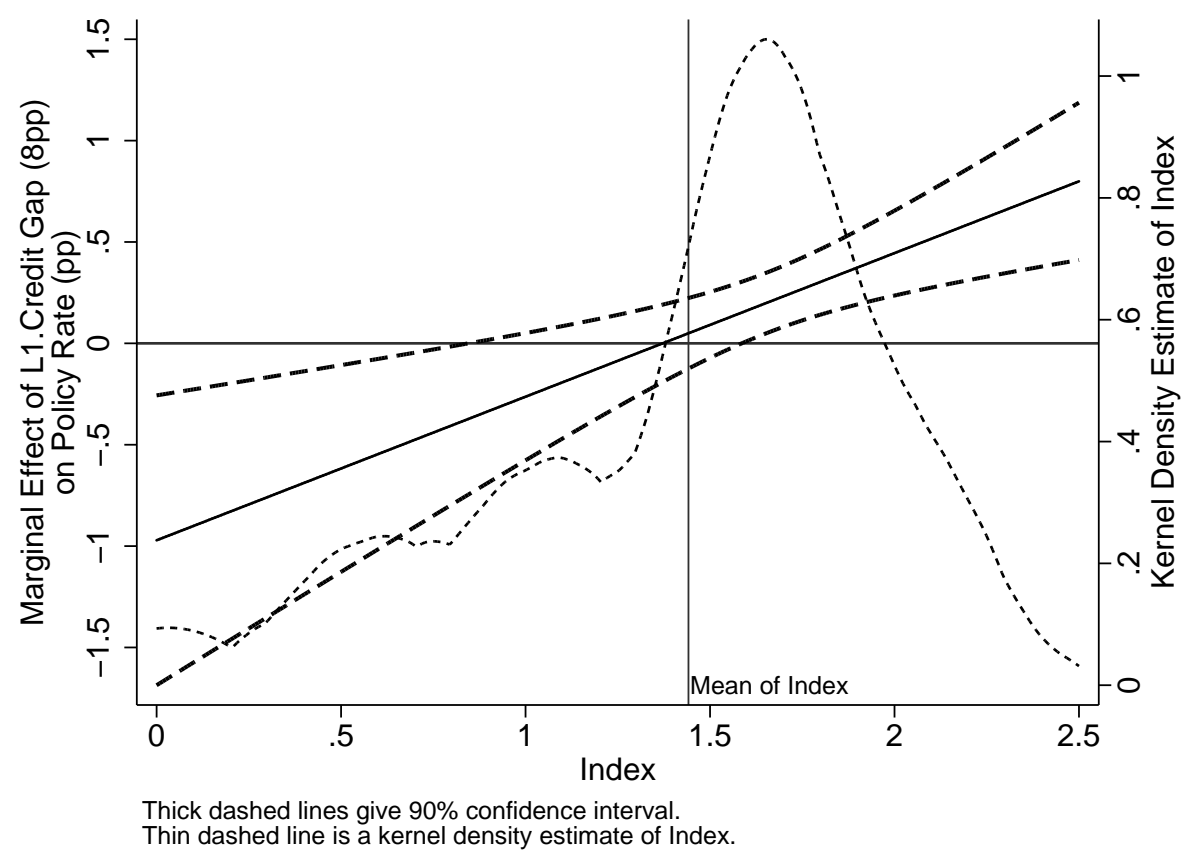

Figure 5: Marginal Effect of Credit Gap Indicator (8pp) on Policy Rate at Different FSO Index Values; Estimated Over 2000Q1-2014Q4 with Country Effects, Including Japan

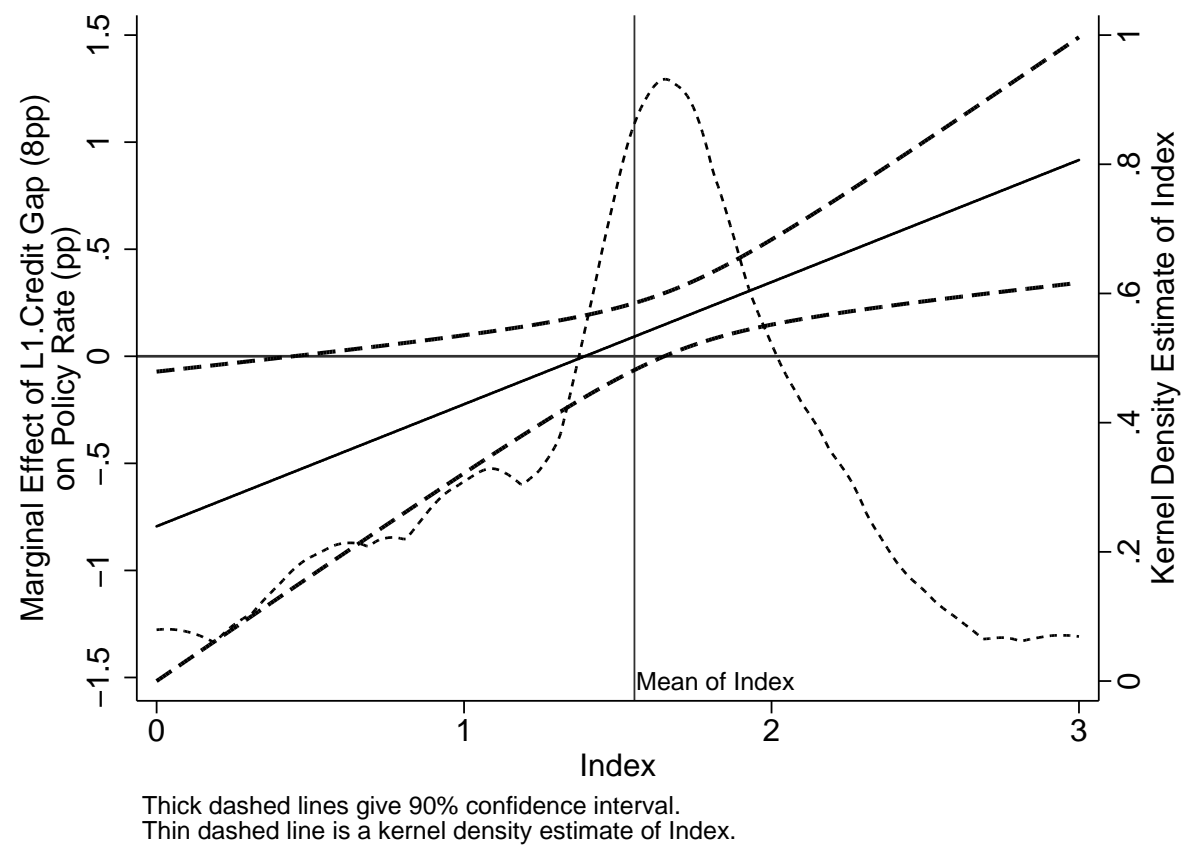


An alternative way to visualize the impact of our findings is to conduct a country-specific historical decomposition of the policy rate based on the coefficient estimates from the baseline specification. A historical decomposition is characterized by plotting the product of the coefficient times the actual value of each variable in each period. Figure 6 shows the result for the nine countries that are contained in the main sample, along with the actual policy rate presented as a dashed black line.

With the total marginal effect of financial stability, red areas, we observe that the effect on the interest rate is positive, on average. We find that periods where financial stability concerns contribute to higher policy rates occur around the time of the 2008 global financial crisis and more recently during the post-crisis period. This is particularly true in Norway, Sweden and Australia, while we do not observe such behavior for the U.S. (in fact, the U.S. shows even a short period of negative interest rate contributions in the years before the global financial crisis).

The results we have discussed so far have been based on the sample excluding Japan because it seems to be an outlier on several dimensions, as mentioned in Section 4.1. Nevertheless, specifications (8) and (9) report the results of estimating models (6) and (7) including the Japanese data.

As evident in specification (9), the inclusion of Japan in the baseline specification produces a somewhat smaller but still significant coefficient on the interaction term between the measure of financial stability risk and the FSO index of 0.570 (compared with 0.708 before) and thus indicates that our main result is robust to the inclusion of Japan in the sample. Figure 5 presents the corresponding marginal effect chart. It should be noted that now the range of FSO index values in the sample goes up to 3 once Japan is included in the sample. ${ }^{31}$ The slope of the marginal effect line and its intersections with the chart coordinates have a very similar pattern as before and are only marginally affected.

However, specification (8) should be examined with caution, where country fixed effects are absent and the coefficient on the interaction term increases to 2.025 (from 1.565 before). The reasons for this increase are the country-specific experiences for Japan that were highlighted in the beginning of this section, and the fact that a specification without country fixed effects assigns the same intercept to all sample countries. ${ }^{32}$ In addition, even in the baseline specification, some of the coefficients on the macro variables change significantly when Japan is included in the sample. The uninteracted coefficient on the inflation gap increases, for example, from 0.821 to 1.237 when Japan is included. This can be explained by a seemingly higher response of the central bank to deviations of the inflation expectations gap in a case where Japan is included, which is most likely driven by the overall lower level of inflation in Japan. Hence, in the remainder of the paper, we will therefore proceed without Japan and re-estimate the key specifications of this paper with Japan again separately in Table A6 in the Appendix.

\footnotetext{
${ }^{31}$ Even though Japan obtains the highest FSO index value in the sample, the winsorizing procedures for the third dimension of the index are not affected by the inclusion or exclusion of Japan.

${ }^{32}$ The intercept differs consistently over time because time fixed effects are included.
} 
Figure 6: Contribution of Taylor Rule Components to Policy Rate, 2000Q1-2014Q4; Based on Coefficients from Baseline Specification with Country Effects
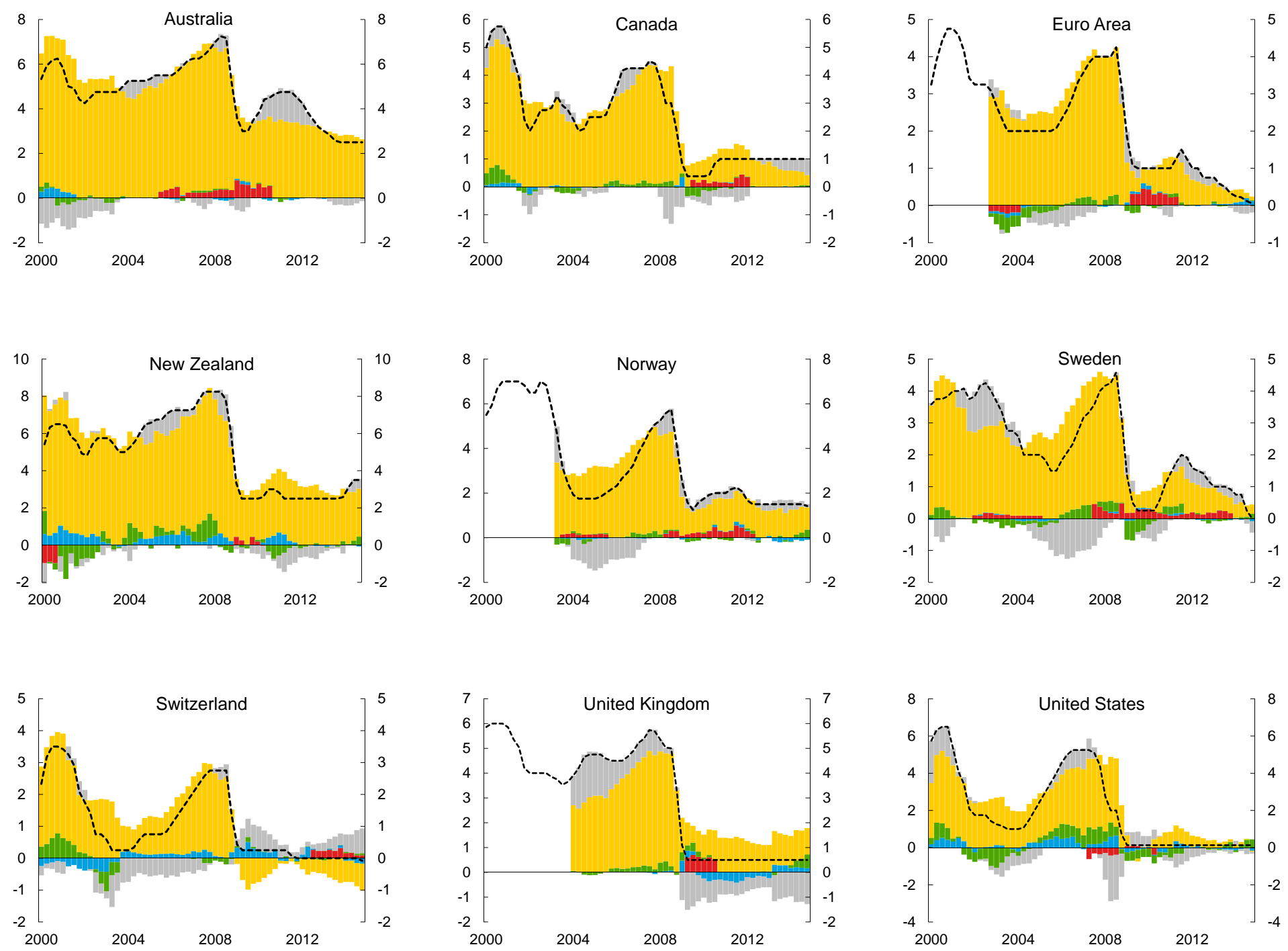

---.-Policy Rate $\square$ Residual $₫$ Time and Country Fixed Effects, FSO Index, and Constant $₫$ Output Gap $\approx$ Inflation Gap $\backsim$ Credit Gap 


\subsection{Assessing the Effect of Different Financial Stability Risks}

Our baseline results show that leaning-type central banks increase their interest rates in times of elevated financial stability risks relative to cleaning-type central banks. The measure of financial stability risk that was employed so far was based on an indicator variable that takes on the value of 1 when the credit-to-GDP gap was higher than 8 percentage points (and 0 otherwise). In this section, we generalize this result to various cut-off values in the credit-to-GDP gap and assess the policy rate response of different central bank types in periods where high credit growth is combined with imbalances in other financial markets, such as housing and equity.

Table 3 presents the results of specifications (6) and (7) at different cut-offs for the credit-toGDP gap. We show the results for credit gaps of $2,4,6,8$ and 10 percentage points, where the two 8-percentage-point specifications correspond to specifications (6) and (7) in Table 2. We only present results for credit gaps of up to 10 percentage points because booms identified by higher cut-offs are not very frequent in the sample. ${ }^{33}$

The results in Table 3 indicate that leaning-type central banks have higher interest rate responses to periods of elevated financial stability risk for all the thresholds considered here given that all 10 specifications contain the expected positive and significant coefficient on the interaction term of the financial stability risk variable and the FSO index. As expected, for the total FS marginal effect for a representative leaning-type central bank (i.e., the $75^{\text {th }}$ percentile of the FSO index distribution) is positive and significant in all 10 specifications, while they are insignificant in 7 of the 10 cases for the $25^{\text {th }}$ percentile case of the FSO index, i.e., for the cleaning types.

Overall, the results in Table 3 strongly support the message from our baseline specification, namely that, ceteris paribus, representative leaning-type central banks increase their interest rates by around 0.30 percentage points (up to 0.45 percentage points depending on the financial stability risk measure) in times of elevated financial stability risks, a finding that is consistent across various measures of financial stability risks in the credit market.

Recent work by Jordà, Schularick and Taylor (2015) shows that at least since the 1870s, economic crises were more severe when they involved a combination of high credit growth and high asset price growth, particularly house price growth. We therefore examine whether central banks respond stronger to joint financial stability risks in the credit and the housing markets or in the credit and the equity markets than they do in periods where such risks are present only in the credit market. ${ }^{34}$

Table 4 presents the results for various combinations of the credit gap measures introduced in Table 3 and different cut-offs for real house price gaps. Panel I contains a memo line that restates the coefficients of the interaction terms between the financial stability risk measure and the FSO index from Table 3 for comparison with the interaction terms that are based on the FSO index and the joint financial stability risk measure. Panels II to IV then present the results for the interaction terms and direct effects of the financial stability risk variable at increasingly higher cut-offs for the

\footnotetext{
${ }^{33}$ In addition to Japan, where only the 2 percentage point cut-off produces a non-zero value in the financial stability risk indicator, the euro area records zero values already for cut-offs of 10 percentage points. For a cut-off of 12 percentage points, about half the sample countries experience a zero value in the financial stability risk measure.

${ }^{34}$ We would not necessarily expect that central banks in the early part of the sample period were fully aware of the additional risks associated with a combined boom in credit and in asset prices.
} 
Table 3: Taylor Rule Estimation at Various Thresholds of the Credit Gap Financial Stability Indicator, 2000Q1-2014Q4

\begin{tabular}{|c|c|c|c|c|c|c|c|c|c|c|}
\hline & \multicolumn{2}{|c|}{ Credit Gap (2pp) } & \multicolumn{2}{|c|}{ Credit Gap (4pp) } & \multicolumn{2}{|c|}{ Credit Gap (6pp) } & \multicolumn{2}{|c|}{ Credit Gap (8pp) } & \multicolumn{2}{|c|}{ Credit Gap (10pp) } \\
\hline & $(1)$ & $(2)$ & $(3)$ & $(4)$ & $(5)$ & $(6)$ & $(7)$ & $(8)$ & $(9)$ & $(10)$ \\
\hline Output Gap & $\begin{array}{c}0.533^{* * *} \\
(0.00)\end{array}$ & $\begin{array}{c}0.663^{* * *} \\
(0.00)\end{array}$ & $\begin{array}{c}0.387^{* *} \\
(0.03)\end{array}$ & $\begin{array}{c}0.643^{* * *} \\
(0.00)\end{array}$ & $\begin{array}{c}0.351^{* *} \\
(0.04)\end{array}$ & $\begin{array}{c}0.657^{* * *} \\
(0.00)\end{array}$ & $\begin{array}{c}0.504^{* * *} \\
(0.00)\end{array}$ & $\begin{array}{c}0.679^{* * *} \\
(0.00)\end{array}$ & $\begin{array}{c}0.520^{* * *} \\
(0.00)\end{array}$ & $\begin{array}{c}0.688^{* * *} \\
(0.00)\end{array}$ \\
\hline Inflation Gap & $\begin{array}{c}2.244^{* * *} \\
(0.00)\end{array}$ & $\begin{array}{c}0.862^{* * *} \\
(0.00)\end{array}$ & $\begin{array}{c}2.481^{* * *} \\
(0.00)\end{array}$ & $\begin{array}{c}0.913^{* * *} \\
(0.00)\end{array}$ & $\begin{array}{c}2.460^{* * *} \\
(0.00)\end{array}$ & $\begin{array}{c}0.878^{* * *} \\
(0.00)\end{array}$ & $\begin{array}{c}2.250^{* * *} \\
(0.00)\end{array}$ & $\begin{array}{c}0.821^{* * *} \\
(0.00)\end{array}$ & $\begin{array}{c}2.135^{* * *} \\
(0.00)\end{array}$ & $\begin{array}{c}0.786^{* * *} \\
(0.00)\end{array}$ \\
\hline L1.Credit Gap & $\begin{array}{c}-0.223 \\
(0.64)\end{array}$ & $\begin{array}{c}-0.417^{*} \\
(0.09)\end{array}$ & $\begin{array}{c}-1.348^{* * *} \\
(0.00)\end{array}$ & $\begin{array}{c}-0.402^{*} \\
(0.09)\end{array}$ & $\begin{array}{c}-2.273^{\text {*** }} \\
(0.00)\end{array}$ & $\begin{array}{r}-0.456 \\
(0.11)\end{array}$ & $\begin{array}{c}-2.017^{* * *} \\
(0.00)\end{array}$ & $\begin{array}{c}-0.971^{* *} \\
(0.03)\end{array}$ & $\begin{array}{c}-4.947^{* * *} \\
(0.00)\end{array}$ & $\begin{array}{c}-1.567^{*} \\
(0.10)\end{array}$ \\
\hline FSO Index & $\begin{array}{r}-0.424^{*} \\
(0.08)\end{array}$ & $\begin{array}{c}-0.580^{* * *} \\
(0.00)\end{array}$ & $\begin{array}{c}-0.698^{* * *} \\
(0.00)\end{array}$ & $\begin{array}{c}-0.508^{* * *} \\
(0.00)\end{array}$ & $\begin{array}{c}-0.679^{* * *} \\
(0.00)\end{array}$ & $\begin{array}{c}-0.440^{* * *} \\
(0.00)\end{array}$ & $\begin{array}{c}-0.375^{* *} \\
(0.02)\end{array}$ & $\begin{array}{c}-0.465^{* * *} \\
(0.00)\end{array}$ & $\begin{array}{c}-0.332^{* *} \\
(0.03)\end{array}$ & $\begin{array}{c}-0.362^{* *} \\
(0.01)\end{array}$ \\
\hline L1.Credit Gap x Index & $\begin{array}{c}0.575^{*} \\
(0.05)\end{array}$ & $\begin{array}{c}0.485^{* * *} \\
(0.00)\end{array}$ & $\begin{array}{c}1.229^{* * *} \\
(0.00)\end{array}$ & $\begin{array}{c}0.484^{* * *} \\
(0.00)\end{array}$ & $\begin{array}{c}1.691^{* * *} \\
(0.00)\end{array}$ & $\begin{array}{c}0.436^{* *} \\
(0.02)\end{array}$ & $\begin{array}{c}1.565^{* * *} \\
(0.00)\end{array}$ & $\begin{array}{c}0.708^{* * *} \\
(0.01)\end{array}$ & $\begin{array}{c}3.266^{* * *} \\
(0.00)\end{array}$ & $\begin{array}{c}1.120^{* *} \\
(0.04)\end{array}$ \\
\hline O.Gap x Index & $\begin{array}{c}-0.260^{* *} \\
(0.02)\end{array}$ & $\begin{array}{c}-0.333^{* * *} \\
(0.00)\end{array}$ & $\begin{array}{c}-0.188 \\
(0.11)\end{array}$ & $\begin{array}{c}-0.322^{\text {*** }} \\
(0.00)\end{array}$ & $\begin{array}{c}-0.154 \\
(0.15)\end{array}$ & $\begin{array}{c}-0.323^{* * *} \\
(0.00)\end{array}$ & $\begin{array}{c}-0.239^{* *} \\
(0.02)\end{array}$ & $\begin{array}{c}-0.337^{* * *} \\
(0.00)\end{array}$ & $\begin{array}{c}-0.239^{* *} \\
(0.01)\end{array}$ & $\begin{array}{c}-0.333^{* * *} \\
(0.00)\end{array}$ \\
\hline Inf. Gap x Index & $\begin{array}{c}-0.768^{* * *} \\
(0.00)\end{array}$ & $\begin{array}{c}-0.460^{* * *} \\
(0.00)\end{array}$ & $\begin{array}{c}-0.921^{* * *} \\
(0.00)\end{array}$ & $\begin{array}{c}-0.484^{* * *} \\
(0.00)\end{array}$ & $\begin{array}{c}-0.908^{* * *} \\
(0.00)\end{array}$ & $\begin{array}{c}-0.484^{* * *} \\
(0.00)\end{array}$ & $\begin{array}{c}-0.790^{* * *} \\
(0.00)\end{array}$ & $\begin{array}{c}-0.481^{* * *} \\
(0.00)\end{array}$ & $\begin{array}{c}-0.718^{* * *} \\
(0.00)\end{array}$ & $\begin{array}{c}-0.447^{* * *} \\
(0.00)\end{array}$ \\
\hline Time Fixed Effects & Yes & Yes & Yes & Yes & Yes & Yes & Yes & Yes & Yes & Yes \\
\hline Country Fixed Effects & No & Yes & No & Yes & No & Yes & No & Yes & No & Yes \\
\hline $\mathrm{R} 2$ & 0.67 & 0.89 & 0.68 & 0.89 & 0.69 & 0.89 & 0.68 & 0.89 & 0.69 & 0.89 \\
\hline $\mathrm{N}$ & 500 & 500 & 500 & 500 & 500 & 500 & 500 & 500 & 500 & 500 \\
\hline Countries & 9 & 9 & 9 & 9 & 9 & 9 & 9 & 9 & 9 & 9 \\
\hline Total FS Effect, 25pctl & $0.410^{* *}$ & 0.117 & 0.005 & 0.131 & $-0.410^{* *}$ & 0.025 & -0.292 & -0.191 & $-1.349^{* * *}$ & -0.333 \\
\hline p-value & 0.02 & 0.26 & 0.97 & 0.17 & 0.01 & 0.82 & 0.24 & 0.26 & 0.00 & 0.35 \\
\hline Total FS Effect, 75pctl & $0.805^{* * *}$ & $0.451^{* * *}$ & $0.849^{* * *}$ & $0.464^{* * *}$ & $0.751^{* * *}$ & $0.324^{* * *}$ & $0.782^{* * *}$ & $0.295^{* * *}$ & $0.892^{* * *}$ & $0.436^{* * *}$ \\
\hline $\mathrm{p}$-value & 0.00 & 0.00 & 0.00 & 0.00 & 0.00 & 0.00 & 0.00 & 0.00 & 0.00 & 0.00 \\
\hline
\end{tabular}

The financial stability indicators are calculated from thresholds of 2 to 10 percentage points (pp) of a credit gap measure smoothed over 8 lags.

All specifications include a constant. p-values in parentheses. ${ }^{*} p<0.10,{ }^{* *} p<0.05,{ }^{* * *} p<0.01$ 
Table 4: Taylor Rule Estimation with Financial Stability Indicators of Credit (C) and Real House Price (HP) Gaps, 2000Q1-2014Q4

\begin{tabular}{|c|c|c|c|c|c|c|c|c|c|c|}
\hline & (1) & $(2)$ & (3) & $(4)$ & $(5)$ & $(6)$ & $(7)$ & $(8)$ & $(9)$ & $(10)$ \\
\hline Panel I: Memo & \multicolumn{2}{|c|}{ Credit (2 pp) } & \multicolumn{2}{|c|}{ Credit (4pp) } & \multicolumn{2}{|c|}{ Credit (6 pp) } & \multicolumn{2}{|c|}{ Credit (8 pp) } & \multicolumn{2}{|c|}{ Credit (10 pp) } \\
\hline L1. Fin. Stability Indicator $\mathrm{x}$ Index & $0.575^{*}$ & $0.485^{* * *}$ & $1.229^{* *}$ & $0.484^{* * *}$ & $1.691^{* *}$ & $0.436^{* *}$ & $1.565^{* *}$ & $0.708^{* * *}$ & $3.266^{* *}$ & $1.120^{* *}$ \\
\hline
\end{tabular}

\begin{tabular}{|c|c|c|c|c|c|c|c|c|c|c|}
\hline Panel II: C (2-10 pp) and HP (2pp) & \multicolumn{2}{|c|}{$\mathrm{C}(2) \& \operatorname{HP}(2)$} & \multicolumn{2}{|c|}{$\mathrm{C}(4) \& \operatorname{HP}(2)$} & \multicolumn{2}{|c|}{$\mathrm{C}(6) \& \operatorname{HP}(2)$} & \multicolumn{2}{|c|}{$\mathrm{C}(8) \& \operatorname{HP}(2)$} & \multicolumn{2}{|c|}{$\mathrm{C}(10) \& \operatorname{HP}(2)$} \\
\hline L1. Fin. Stability Indicator & $\begin{array}{c}-1.121^{* * *} \\
(0.00)\end{array}$ & $\begin{array}{c}-0.313 \\
(0.16)\end{array}$ & $\begin{array}{c}-1.750^{* * *} \\
(0.00)\end{array}$ & $\begin{array}{c}-0.430^{*} \\
(0.09)\end{array}$ & $\begin{array}{c}-2.451^{* * *} \\
(0.00)\end{array}$ & $\begin{array}{c}-0.504^{*} \\
(0.09)\end{array}$ & $\begin{array}{c}-2.255^{* * *} \\
(0.00)\end{array}$ & $\begin{array}{c}-1.201^{* * *} \\
(0.01)\end{array}$ & $\begin{array}{c}-5.469^{* * *} \\
(0.00)\end{array}$ & $\begin{array}{c}-1.994^{* *} \\
(0.04)\end{array}$ \\
\hline L1. Fin. Stability Indicator $x$ Index & $\begin{array}{c}1.162^{* * *} \\
(0.00)\end{array}$ & $\begin{array}{c}0.388^{* * *} \\
(0.01)\end{array}$ & $\begin{array}{c}1.505^{* * *} \\
(0.00)\end{array}$ & $\begin{array}{c}0.464^{* * *} \\
(0.00)\end{array}$ & $\begin{array}{c}1.838^{* * *} \\
(0.00)\end{array}$ & $\begin{array}{c}0.450^{* *} \\
(0.02)\end{array}$ & $\begin{array}{c}1.740^{* * *} \\
(0.00)\end{array}$ & $\begin{array}{c}0.830^{* * *} \\
(0.00)\end{array}$ & $\begin{array}{c}3.579^{* * *} \\
(0.00)\end{array}$ & $\begin{array}{c}1.337^{* *} \\
(0.02)\end{array}$ \\
\hline Total FS Effect, 25pctl & 0.159 & 0.114 & -0.092 & 0.081 & $-0.427^{* *}$ & -0.009 & -0.338 & $-0.287^{*}$ & $-1.526^{* * *}$ & -0.520 \\
\hline Total FS Effect, 75pctl & $0.956^{* * *}$ & $0.381^{* * *}$ & $0.941^{* * *}$ & $0.399^{* * *}$ & $0.834^{* * *}$ & $0.300 * * *$ & $0.855^{* * *}$ & $0.283^{* *}$ & $0.930 * * *$ & $0.398 * * *$ \\
\hline
\end{tabular}

Total FS Effect, 75pctl

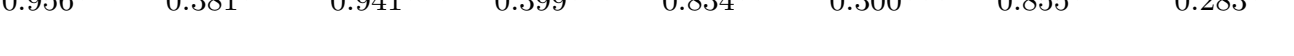

Panel III: C (2-10pp) and HP (4pp)

L1. Fin. Stability Indicator

\begin{tabular}{ccccc}
\multicolumn{2}{c}{$\mathrm{C}(2) \& \mathrm{HP}(4)$} & & \multicolumn{2}{c}{$\mathrm{C}(4) \& \mathrm{HP}(4)$} \\
\cline { 1 - 2 } \cline { 5 - 5 }$-1.273^{* * *}$ & -0.332 & & $-1.962^{* * *}$ & $-0.464^{*}$ \\
$(0.00)$ & $(0.15)$ & & $(0.00)$ & $(0.08)$ \\
$1.241^{* * *}$ & $0.392^{* * *}$ & & $1.618^{* * *}$ & $0.474^{* * *}$ \\
$(0.00)$ & $(0.01)$ & & $(0.00)$ & $(0.00)$ \\
\cline { 1 - 2 } \cline { 5 - 6 } 0.094 & 0.100 & & -0.180 & 0.059 \\
$0.946^{* * *}$ & $0.368^{* * *}$ & & $0.930^{* * *}$ & $0.385^{* * *}$
\end{tabular}

\begin{tabular}{cc}
\multicolumn{2}{c}{$\mathrm{C}(6) \& \mathrm{HP}(4)$} \\
\hline$-2.752^{* * *}$ & $-0.550^{*}$ \\
$(0.00)$ & $(0.09)$ \\
$2.004^{* * *}$ & $0.473^{* *}$ \\
$(0.00)$ & $(0.02)$ \\
\hline$-0.545^{* * *}$ & -0.029 \\
$0.830^{* * *}$ & $0.296^{* * *}$
\end{tabular}

\begin{tabular}{cc}
\multicolumn{2}{c}{$\mathrm{C}(8) \& \mathrm{HP}(4)$} \\
\hline$-2.419^{* * *}$ & $-1.286^{* * *}$ \\
$(0.00)$ & $(0.01)$ \\
$1.832^{* * *}$ & $0.875^{* * *}$ \\
$(0.00)$ & $(0.00)$ \\
\hline-0.400 & $-0.323^{*}$ \\
$0.857^{* * *}$ & $0.277^{* *}$
\end{tabular}

\begin{tabular}{cc}
$\mathrm{C}(10) \& \mathrm{HP}(4)$ \\
\hline$-6.096^{* * *}$ & $-2.306^{* *}$ \\
$(0.00)$ & $(0.02)$ \\
$3.963^{* * *}$ & $1.532^{* * *}$ \\
$(0.00)$ & $(0.01)$ \\
\hline$-1.731^{* * *}$ & $-0.619^{*}$ \\
$0.988^{* * *}$ & $0.432^{* * *}$
\end{tabular}

Total FS Effect, 25pctl
Total FS Effect, 75 pctl

$\mathrm{C}(2) \& \operatorname{HP}(6)$

Panel IV: C (2-10pp) and HP (6pp)

L1. Fin. Stability Indicator

\begin{tabular}{ccccc}
\multicolumn{2}{c}{$\mathrm{C}(2) \& \mathrm{HP}(6)$} & & \multicolumn{2}{c}{$\mathrm{C}(4) \& \mathrm{HP}(6)$} \\
\cline { 1 - 2 } \cline { 5 - 5 }$-1.482^{* * *}$ & -0.102 & & $-2.145^{* * *}$ & -0.364 \\
$(0.00)$ & $(0.70)$ & & $(0.00)$ & $(0.23)$ \\
$1.273^{* * *}$ & 0.201 & & $1.665^{* * *}$ & $0.365^{*}$ \\
$(0.00)$ & $(0.22)$ & & $(0.00)$ & $(0.05)$ \\
\cline { 1 - 2 } \cline { 1 - 1 }-0.080 & 0.120 & & $-0.310^{* *}$ & 0.037 \\
$0.793^{* * *}$ & $0.257^{* * *}$ & & $0.832^{* * *}$ & $0.288^{* * *}$
\end{tabular}

\begin{tabular}{cc}
\multicolumn{2}{c}{$\mathrm{C}(6) \& \mathrm{HP}(6)$} \\
\hline$-3.105^{* * *}$ & -0.471 \\
$(0.00)$ & $(0.23)$ \\
$2.165^{* * *}$ & $0.400^{*}$ \\
$(0.00)$ & $(0.09)$ \\
\hline$-0.720^{* * *}$ & -0.030 \\
$0.765^{* * *}$ & $0.244^{* *}$
\end{tabular}

\begin{tabular}{ccccc}
\multicolumn{2}{c}{$\mathrm{C}(8)$} & $\mathrm{HP}(6)$ & & \multicolumn{2}{c}{$\mathrm{C}(10) \& \mathrm{HP}(6)$} \\
\cline { 1 - 2 } \cline { 5 - 5 }$-3.799^{* * *}$ & $-1.662^{* *}$ & & $-6.073^{* * *}$ & $-2.241^{* *}$ \\
$(0.00)$ & $(0.01)$ & & $(0.00)$ & $(0.02)$ \\
$2.596^{* * *}$ & $1.078^{* * *}$ & & $3.916^{* * *}$ & $1.475^{* * *}$ \\
$(0.00)$ & $(0.01)$ & & $(0.00)$ & $(0.01)$ \\
\cline { 1 - 2 } \cline { 5 - 6 }$-0.939^{* * * *}$ & $-0.475^{*}$ & & $-1.759^{* * *}$ & -0.616 \\
$0.843^{* * *}$ & $0.264^{* *}$ & & $0.928^{* * *}$ & $0.397^{* * *}$
\end{tabular}

\begin{tabular}{|c|c|c|c|c|c|c|c|c|c|c|}
\hline Macro Variables & Yes & Yes & Yes & Yes & Yes & Yes & Yes & Yes & Yes & Yes \\
\hline Macro x Index & Yes & Yes & Yes & Yes & Yes & Yes & Yes & Yes & Yes & Yes \\
\hline Time Fixed Effects & Yes & Yes & Yes & Yes & Yes & Yes & Yes & Yes & Yes & Yes \\
\hline Country Fixed Effects & No & Yes & No & Yes & No & Yes & No & Yes & No & Yes \\
\hline $\mathrm{N}$ & 500 & 500 & 500 & 500 & 500 & 500 & 500 & 500 & 500 & 500 \\
\hline Countries & 9 & 9 & 9 & 9 & 9 & 9 & 9 & 9 & 9 & 9 \\
\hline
\end{tabular}

Threshold values are reported in percentage points (pp). Financial stability indicators are calculated from credit and house price gap measures that are smoothed over 8 lags. $\mathrm{R}^{2}$ values are from 0.68 to 0.71 for specifications without country fixed effects, and from 0.89 to 0.90 for those with country fixed effects. All specifications include a constant. p-values in parentheses. ${ }^{*} p<0.10,{ }^{* *} p<0.05,{ }^{* * *} p<0.01$ 
real house price gap. ${ }^{35}$ The cut-offs comprise 2, 4, and 6 percentage points above the estimated long-run trend. Overall, the table contains the results of 15 credit and real house price cut-off combinations, each estimated for both sets of fixed effects (i.e., with and without country fixed effects). Out of these 30 specifications, 29 contain a positive and significant interaction term on the financial stability risk measure and the FSO index. Further, the total marginal effects for a representative leaning-type central bank are positive and highly significant in all 30 cases. The total marginal effects for a representative cleaning-type central bank are insignificant in 18 cases. This reiterates the previous findings that leaning-type central banks also rely on higher interest rates when joint financial stability risk in the credit and the housing markets are present.

Do leaning-type central banks respond more strongly in the presence of the joint risks? We answer this question by comparing the interaction term coefficients in Panels II-IV with the interaction term coefficients of the memo line in Panel I (which was based on the credit-to-GDP gap cut-offs alone). Moving down within each of the 10 columns from the top to the bottom, we see that the size of the interaction terms based on the joint financial stability risk measures increase relative to both the previous panel and the first panel with the memo line.

Similar to the previous table, the interaction terms also increase when we move to higher cutoffs on the right. Overall, this leads to a tendency for coefficients in this table to increase the more we move from the top left to the bottom right, suggesting that strong leaning-type central banks reduce their interest rate more when financial imbalances appear not only in the credit but also in the housing market. ${ }^{36}$ As in the previous table, however, we see that the total marginal effects themselves are relatively constant across specifications so that the result holds mainly for strong leaning-type central banks.

We also examine the joint presence of financial stability risks in the credit and the equity markets. Table 5 shows the corresponding results for varying cut-offs in the credit-to-GDP gap and the real equity price gap. ${ }^{37}$ Again, Panel I contains the memo line with the coefficients from the specifications that rely on different cut-offs of the credit-to-GDP ratio as a measure of financial stability risk. Panels II to IV combine the same credit cut-offs with real equity price gap cut-offs as previously with real house price gap cut-offs. Because the real equity price series has been historically more volatile, however, the cut-offs are higher and amount to 5, 10 and 20 percentage points.

When focusing on the interaction terms of the joint measure of credit and equity price imbalances with the FSO index, we find a substantially lower number of significant interaction terms. In 20 out of 30 cases, the interaction term is insignificant, suggesting that even leaning-type central banks do not react more aggressively to a joint presence of credit booms and real equity price booms. Of the significant interaction terms, there are six negative and four positive coefficients. While their

\footnotetext{
${ }^{35}$ Table 4 only reports the coefficients used to calculate the total marginal effects. The values on the other coefficients have a similar pattern as in previous tables.

${ }^{36}$ An earlier version of this paper used an indicator variable that takes on the value of one when housing prices or household debt levels are high relative to their trend and found the same result. However, since the household debt variable is not available before the year 2000, it is very difficult to separate trend movements from cyclical movements in this variable, which is why the variable is not used in the current version.

${ }^{37}$ As explained in the data section, the real equity price gap variable is based on a shorter smoothing procedure (four quarters instead of eight) since equity prices are more volatile than housing markets. However, almost exactly the same results are obtained when an eight-quarter smoothing procedure is used.
} 
Table 5: Taylor Rule Estimation with Financial Stability Indicators of Credit(C) and Real Equity Price (EP) Gaps, 2000Q1-2014Q4

\begin{tabular}{|c|c|c|c|c|c|c|c|c|c|c|}
\hline & (1) & $(2)$ & (3) & $(4)$ & $(5)$ & (6) & (7) & $(8)$ & (9) & $(10)$ \\
\hline Panel I: Memo & \multicolumn{2}{|c|}{ Credit (2 pp) } & \multicolumn{2}{|c|}{ Credit (4pp) } & \multicolumn{2}{|c|}{ Credit (6 pp) } & \multicolumn{2}{|c|}{ Credit (8 pp) } & \multicolumn{2}{|c|}{ Credit (10 pp) } \\
\hline L1. Fin. Stability Indicator $x$ Index & $0.575^{*}$ & $0.485^{* * *}$ & $1.229^{* *}$ & $0.484^{* * *}$ & $1.691^{* *}$ & $0.436^{* *}$ & $1.565^{* *}$ & $0.708^{* *}$ & $3.266^{*}$ & $1.120^{*}$ \\
\hline
\end{tabular}

\begin{tabular}{|c|c|c|c|c|c|c|c|c|c|c|}
\hline Panel II: C (2-10pp) and EP (5pp) & \multicolumn{2}{|c|}{$\mathrm{C}(2) \& \mathrm{EP}(5)$} & \multicolumn{2}{|c|}{$\mathrm{C}(4) \& \mathrm{EP}(5)$} & \multicolumn{2}{|c|}{$\mathrm{C}(6) \& \mathrm{EP}(5)$} & \multicolumn{2}{|c|}{$\mathrm{C}(8) \& \mathrm{EP}(5)$} & \multicolumn{2}{|c|}{$\mathrm{C}(10) \& \operatorname{EP}(5)$} \\
\hline L1. Fin. Stability Indicator & $\begin{array}{c}1.864^{* * *} \\
(0.00)\end{array}$ & $\begin{array}{c}1.112^{* * *} \\
(0.00)\end{array}$ & $\begin{array}{c}2.208^{* * *} \\
(0.00)\end{array}$ & $\begin{array}{l}0.695 \\
(0.11)\end{array}$ & $\begin{array}{c}2.624^{* * *} \\
(0.00)\end{array}$ & $\begin{array}{c}1.251^{* *} \\
(0.03)\end{array}$ & $\begin{array}{l}-1.217 \\
(0.58)\end{array}$ & $\begin{array}{c}2.518^{* * *} \\
(0.00)\end{array}$ & $\begin{array}{c}-4.135^{* *} \\
(0.05)\end{array}$ & $\begin{array}{l}1.973^{*} \\
(0.06)\end{array}$ \\
\hline L1. Fin. Stability Indicator $x$ Index & $\begin{array}{l}-0.517 \\
(0.18)\end{array}$ & $\begin{array}{c}-0.658^{* * *} \\
(0.00)\end{array}$ & $\begin{array}{l}-0.635 \\
(0.19)\end{array}$ & $\begin{array}{r}-0.306 \\
(0.23)\end{array}$ & $\begin{array}{l}-0.825 \\
(0.13)\end{array}$ & $\begin{array}{l}-0.540 \\
(0.10)\end{array}$ & $\begin{array}{l}1.548 \\
(0.24)\end{array}$ & $\begin{array}{c}-1.117^{* *} \\
(0.02)\end{array}$ & $\begin{array}{c}3.276^{* * *} \\
(0.01)\end{array}$ & $\begin{array}{c}-0.794 \\
(0.20)\end{array}$ \\
\hline Total FS Effect, 25pctl & $1.295^{* * *}$ & $0.387^{* *}$ & $1.509^{* * *}$ & $0.358^{*}$ & $1.715^{* * *}$ & $0.656^{* *}$ & 0.488 & $1.287^{* * *}$ & -0.527 & $1.098^{* * *}$ \\
\hline Total FS Effect, 75pctl & $0.941^{* * *}$ & -0.065 & $1.073^{* * *}$ & 0.147 & $1.149^{* * *}$ & $0.286^{*}$ & $1.551^{* * *}$ & $0.520 * * *$ & $1.722^{* * *}$ & $0.552^{* * *}$ \\
\hline
\end{tabular}

Total FS Effect, 75pctl

$1.073 * *-0.147$

Panel III: C (2-10pp) and EP (10pp)

L1. Fin. Stability Indicator

\begin{tabular}{ccccc}
\multicolumn{2}{c}{$\mathrm{C}(2) \& \mathrm{EP}(10)$} & & \multicolumn{2}{c}{$\mathrm{C}(4) \& \mathrm{EP}(10)$} \\
\cline { 1 - 2 } \cline { 5 - 5 } $1.838^{* * *}$ & $1.386^{* * *}$ & & $2.415^{* * *}$ & $1.074^{* *}$ \\
$(0.00)$ & $(0.00)$ & & $(0.00)$ & $(0.01)$ \\
-0.426 & $-0.799^{* * *}$ & & -0.636 & $-0.482^{*}$ \\
$(0.31)$ & $(0.00)$ & & $(0.23)$ & $(0.06)$ \\
${$\cline { 1 - 2 }$} }$ & $0.505^{* * *}$ & & $1.715^{* * *}$ & $0.543^{* *}$ \\
$1.077^{* * *}$ & -0.043 & & $1.278^{* * *}$ & 0.212
\end{tabular}

\begin{tabular}{cc}
\multicolumn{2}{c}{$\mathrm{C}(6) \& \mathrm{EP}(10)$} \\
\hline $2.822^{* * *}$ & $1.240^{* *}$ \\
$(0.00)$ & $(0.04)$ \\
-0.784 & -0.491 \\
$(0.16)$ & $(0.16)$ \\
\hline $1.958^{* * *}$ & $0.699^{* *}$ \\
$1.419^{* * *}$ & $0.362^{*}$
\end{tabular}

\begin{tabular}{cc}
$\mathrm{C}(8)$ & $\& \mathrm{EP}(10)$ \\
\hline-0.561 & $2.314^{* *}$ \\
$(0.82)$ & $(0.02)$
\end{tabular}

$\mathrm{C}(10) \& \operatorname{EP}(10)$

L1. Fin. Stability Indicator $x$ Index

Total FS Effect, 25pctl

Total FS Effect, 75pctl

$\mathrm{C}(2) \& \mathrm{EP}(20)$

\begin{tabular}{|c|c|c|c|c|c|c|c|c|c|c|}
\hline Panel IV: C (2-10pp) and EP (20pp) & \multicolumn{2}{|c|}{$\mathrm{C}(2) \& \operatorname{EP}(20)$} & \multicolumn{2}{|c|}{$\mathrm{C}(4) \& \operatorname{EP}(20)$} & \multicolumn{2}{|c|}{$\mathrm{C}(6) \& \operatorname{EP}(20)$} & \multicolumn{2}{|c|}{$\mathrm{C}(8) \& \operatorname{EP}(20)$} & \multicolumn{2}{|c|}{$\mathrm{C}(10) \& \operatorname{EP}(20)$} \\
\hline L1. Fin. Stability Indicator & $\begin{array}{c}1.966^{* * *} \\
(0.00)\end{array}$ & $\begin{array}{c}1.386^{* * *} \\
(0.00)\end{array}$ & $\begin{array}{c}2.977^{* * *} \\
(0.00)\end{array}$ & $\begin{array}{c}0.922^{*} \\
(0.06)\end{array}$ & $\begin{array}{c}3.000^{* * *} \\
(0.00)\end{array}$ & $\begin{array}{l}1.086^{*} \\
(0.08)\end{array}$ & $\begin{array}{c}-10.167^{* * *} \\
(0.00)\end{array}$ & $\begin{array}{l}-0.650 \\
(0.75)\end{array}$ & $\begin{array}{c}-10.129^{* * *} \\
(0.00)\end{array}$ & $\begin{array}{l}-0.873 \\
(0.73)\end{array}$ \\
\hline L1. Fin. Stability Indicator $x$ Index & $\begin{array}{r}-0.401 \\
(0.38)\end{array}$ & $\begin{array}{c}-0.747^{* * *} \\
(0.00)\end{array}$ & $\begin{array}{l}-0.682 \\
(0.12)\end{array}$ & $\begin{array}{r}-0.204 \\
(0.51)\end{array}$ & $\begin{array}{r}-0.531 \\
(0.28)\end{array}$ & $\begin{array}{r}-0.167 \\
(0.65)\end{array}$ & $\begin{array}{c}6.956^{* * *} \\
(0.00)\end{array}$ & $\begin{array}{l}0.787 \\
(0.51)\end{array}$ & $\begin{array}{c}6.935^{* * *} \\
(0.00)\end{array}$ & $\begin{array}{l}0.911 \\
(0.54)\end{array}$ \\
\hline Total FS Effect, 25pctl & $\begin{array}{l}1.525 * * * \\
1250 * * *\end{array}$ & $0.563^{* * *}$ & $\begin{array}{l}2.226 * * * \\
1758 * * *\end{array}$ & $0.697 * * *$ & $2.415^{* * *}$ & $\begin{array}{l}0.902 * * * \\
0.87 * * *\end{array}$ & $\begin{array}{r}-2.504^{* * *} \\
2.270 * * *\end{array}$ & $\begin{array}{c}0.217 \\
0756 * * *\end{array}$ & $\begin{array}{l}-2.489 * * \\
2.270 * * *\end{array}$ & 0.130 \\
\hline Macro Variables & Yes & Yes & Yes & Yes & Yes & Yes & Yes & Yes & Yes & Yes \\
\hline Macro x Index & Yes & Yes & Yes & Yes & Yes & Yes & Yes & Yes & Yes & Yes \\
\hline Time Fixed Effects & Yes & Yes & Yes & Yes & Yes & Yes & Yes & Yes & Yes & Yes \\
\hline Country Fixed Effects & No & Yes & No & Yes & No & Yes & No & Yes & No & Yes \\
\hline $\mathrm{N}$ & 500 & 500 & 500 & 500 & 500 & 500 & 500 & 500 & 500 & 500 \\
\hline Countries & 9 & 9 & 9 & 9 & 9 & 9 & 9 & 9 & 9 & 9 \\
\hline
\end{tabular}

$1.222-1.018^{*}$

\begin{tabular}{ll}
$(0.42)$ & $(0.08)$ \\
\hline 0.785 & $1.192 * * *$
\end{tabular}

0.785

$1.624^{* * *} \quad 0.494^{* *}$

$-4.207^{*} \quad 1.366$

(0.09) (0.33)

$3.376^{* *} \quad-0.466$

\begin{tabular}{cc}
$(0.02)$ & $(0.56)$ \\
\hline-0.488 & 0.852
\end{tabular}

Threshold values are reported in percentage points (pp). Financial stability indicators are calculated from credit and equity price gap measures that are smoothed over 4 lags (though the memo line measure is smoothed over 8 lags). $\mathrm{R}^{2}$ values are from 0.67 to 0.68 for specifications without country fixed effects, and from 0.89 to 0.90 for those with country fixed effects. All specifications include a constant. p-values in parentheses. ${ }^{*} p<0.10,{ }^{* *} p<0.05,{ }^{* * *} p<0.01$ 
pattern should not be overstated, it turns out that all of the positive and significant interaction terms are found toward the bottom and the right side of the table, suggesting that joint imbalances in the credit and the equity market are only addressed when they are substantial in magnitude.

Finally, the pattern of insignificant interaction terms translates into very similar total marginal effects across leaning- and cleaning-type central banks that are often positive and significant. This is not surprising, however, given that this finding largely mirrors an early finding in specifications (2) and (3) from Table 2: The inclusion of a financial stability variable in a simple Taylor rule without the interaction with the FSO index produces a positive coefficient on average.

The overall effect of the financial stability risk variable turns out to be positive when excluding a financial stability risk measure from the specification that in combination with the FSO index leads to a separation of the leaning-type from the cleaning-type behavior (i.e., the real house price gap).

\subsection{Assessing Different Channels}

Section 5.1 has shown that leaning-type central banks appear to increase their interest rates in the presence of elevated financial stability risks and cleaning-type central banks do not. Section 5.2 has generalized this result across different cut-off values in our main measure of financial stability risk, the credit-to-GDP gap, and indicated that the response of leaning-type central banks to financial stability risks is even stronger under the additional presence of a positive real house price gap. We also saw that in the joint presence of credit and equity price imbalances, central banks do not seem to respond with a stronger policy rate increase than they do in the presence of a positive credit-to-GDP gap alone.

Here we incorporate the three FSO index components into the Taylor rule models separately to more closely examine the potential channels that drive the different responses by central bank types to financial stability concerns. Our findings in this section provide substantial evidence that the main results are not driven by alternative explanations, such as the presence of endogeneity,

a misspecification of the Taylor rule equation, or how we define the FSO index or the financial stability risk variables.

\subsubsection{The Individual Dimensions of the FSO Index and their Associated Channels}

Understanding how individual dimensions affect central banks' interest rate decisions is an important step in identifying the key mechanisms that need to be included in theoretical models that are used for policy evaluations and welfare assessments. Table 6 therefore divides the index into its three dimensions; the statutory dimension, the regulatory dimension and the view-based dimension. Each of these components is treated in the same way as the FSO index previously and enters the specification in levels and as an interaction with a financial stability risk variable. Based on our previous results, we use the following set of financial stability risk indicators: the 4,6 , and 8 percentage point cut-off for the credit-to-GDP gap and the 4 and the 6 percentage point cut-off for the joint credit-to-GDP gap and the real house price gap. We also follow the previous practice of presenting the results with and without the inclusion of country fixed effects. Overall, we obtain 10 specifications for each of the three components. The results are presented in Panels II to IV, 
Table 6: Taylor Rule Estimation with Individual FSO Index Dimensions and Financial Stability Indicators of Credit (C) and Real House Price (HP) Gaps, 2000Q1-2014Q4

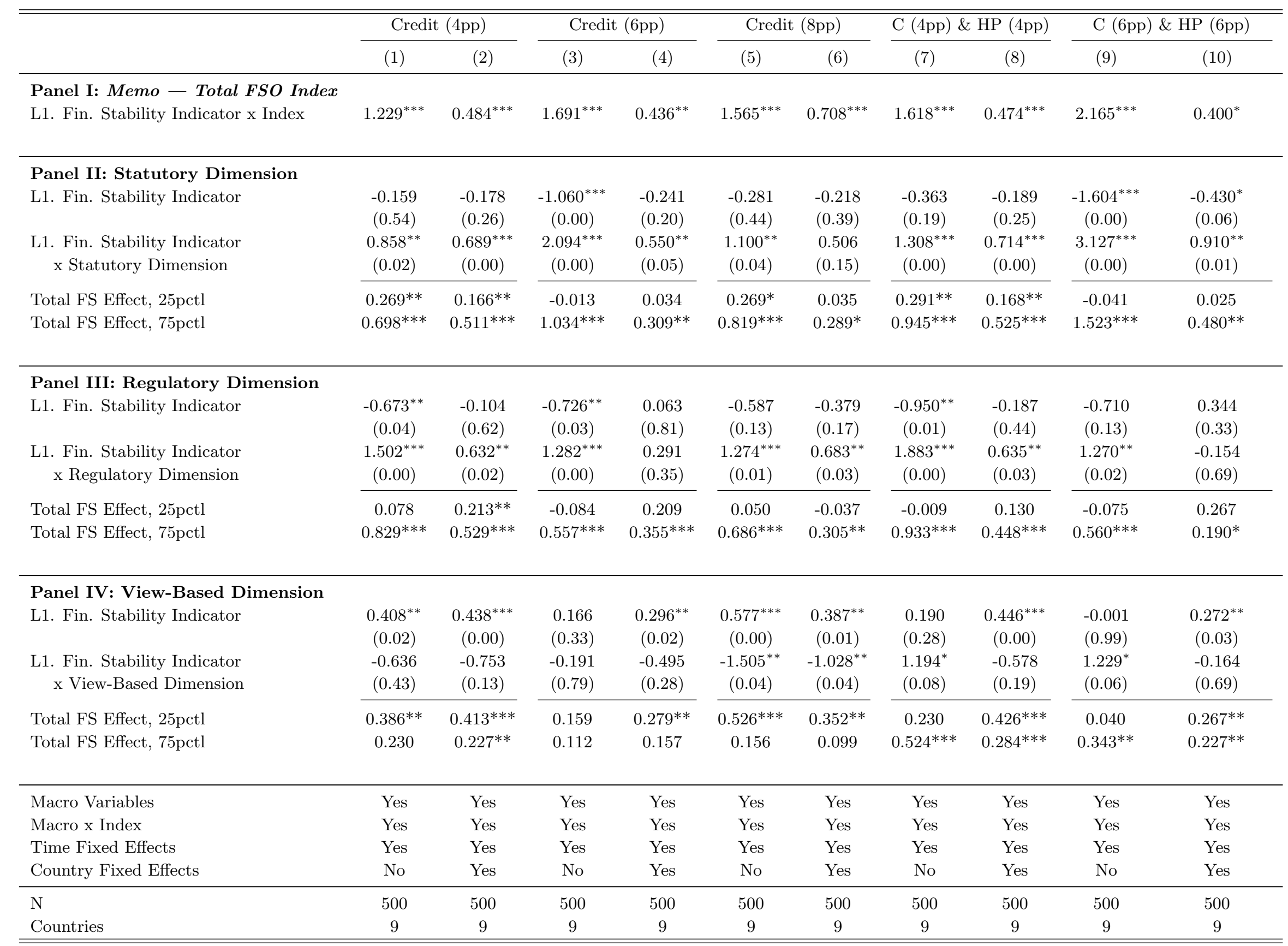

Threshold values are reported in percentage points (pp). Financial stability indicators are calculated from credit and house price gap measures that are smoothed over 8 lags. $\mathrm{R}^{2}$ values are from 0.65 to 0.68 for specifications without country fixed effects, and from 0.88 to 0.89 for those with country fixed effects.

All specifications include a constant. p-values in parentheses. ${ }^{*} p<0.10,{ }^{* *} p<0.05,{ }^{* * *} p<0.01$ 
where Panel I contains the memo line from the previous table again (however, adjusted for the change in the last four specifications from the right).

Starting with the results in Panel II, where the entire FSO index is replaced by the statutory dimension alone, we observe that the interaction term between the first dimension of the FSO index and the financial stability risk measures is positive and highly significant in 9 out of 10 cases.

Accordingly, leaning-type central banks have a positive and significant total marginal effect in all 10 cases. This suggests that a representative leaning-type central bank increases its interest rates in the presence of financial stability risks when its statutory framework favors a leaning orientation. While the results are less clear cut for cleaning-type central banks, their total marginal effect is not different from zero in 5 out of 10 cases and significantly positive in the other 5 cases. It is, however, important to not over-interpret the coefficients and total marginal effects in this case because the other two dimensions of the FSO index potentially contain additional information to separate leaning- from cleaning-type central banks that is omitted when the index dimensions are included individually.

Turning next to the results in Panel III, where the regulatory dimension is substituted for the FSO index, we observe 8 out of 10 positive and significant interaction terms between the second dimension of the index and the various measures of financial stability risk. At the same time, the total marginal effects are positive and significant in all 10 cases, indicating that leaning-type central banks also increase their interest rates in light of financial stability concerns when they have a weaker set of regulatory and macroprudential tools at hand. For cleaning-type central banks, this is not the case and we observe insignificant total marginal effects in 9 out of 10 cases.

Finally, we examine the results in Panel IV, where the view-based dimension is used instead of the FSO index. The results for this dimension are somewhat weaker than for the other two dimensions. The coefficient on the interaction term of the third dimension and the financial stability risk measure is positive and significant in only 2 out of 10 and insignificant in 6 out of 10 cases. Interestingly, however, the two positive and significant coefficients appear in the specifications that are based on the financial stability risk measure that captures the joint presence of a positive creditto-GDP gap and a positive real house price gap. A potential explanation for this finding could be that the discussion of terms related to financial stability in the press releases might not be sufficient to differentiate leaning-type from cleaning-type central banks when imbalances are only present in the credit market. However, at times when both the credit-to-GDP gap and the real house price gap are positive - and thus the perceived financial stability risk of the economy is higher - the discussion of financial stability issues through official communication channels can indeed help to distinguish the two types of central banks from each other.

Overall, this exercise suggests that the first 2 dimensions are the strongest and the third is weakest for differentiating leaning-type from cleaning-type central banks. However, as illustrated above, it is important to remember that the individual inclusion of the three dimensions overlooks the information that is contained in the other two. The discussion of financial stability related topics in official central bank press releases (i.e., the content on which our third dimension is based) can have a very different impact on the interest rate (and thus on the sign of the interaction term), depending on whether the central bank has a statutory framework that facilitates the use of monetary policy to reduce financial stability concerns and whether the regulatory and macroprudential tool kit allows financial stability risks to be addressed directly. The third dimension proxies for 
the other two dimensions when included individually, but when all three dimensions are included jointly (in form of the aggregated FSO index) it is more likely that only the part of the third dimension that is orthogonal to the first two dimensions enters in the specification. As a result, the FSO index should be used as an aggregate.

After having presented evidence that the individual dimensions of the index produce intuitive results, we assess the validity of our arguments from another angle and provide additional evidence that rules out alternative explanations for our findings. In particular, we discuss the role of endogeneity concerns, a potential mismeasurement of the standard Taylor rule determinants, some of the decisions we made when constructing the FSO index, the construction of the financial stability risk variables as well as the decision to exclude Japan from the main sample. Sections 5.3.2 to 5.3.4 contain a detailed assessment of these issues and are supported by a large set of additional results that are presented in Table A3 in the Appendix. Sections 5.3.5 to 5.3.6 work in the same way, but their associated results are contained in Tables A4 to A6 in the Appendix.

\subsubsection{Endogeneity Concerns}

In this section, we discuss the potential presence of endogeneity in our empirical analysis. First, there might be a reverse impact of the interest rate on our measures of financial stability risk. The literature has extensively discussed the existence of a risk-taking channel of monetary policy (e.g., Borio and Zhu 2012). The key argument behind the risk-taking channel is that agents increase their risk-taking actions in times of low interest rates and thus financial imbalances emerge more frequently. We examine the impact of financial stability on policy rates, however, and would

expect leaning-type central banks to respond to financial imbalances with a higher policy rate. The presence of a risk-taking channel should therefore bias our findings toward zero instead of increasing the significance of our results based on an endogeneity problem. Throughout the paper, our measure of financial stability risks enters the specification with the lag of one quarter. Nevertheless, in specifications (1) and (2) of Panel I in Table A3, we also let our measures of financial stability risk enter the specifications with a lag of two quarters. The results are nevertheless very similar, with an interaction term coefficient of 0.828 instead of 0.708 for our baseline specification.

Second, it could be a concern that some elements of the FSO index respond to the policy rate. For the first dimension, the effect is rather low. Changing the legal mandate is not under the direct control of the central banks and comes with a long time lag, in a similar way to changing an inflation target, which is usually not considered to be endogeneous in a standard Taylor rule specification. Changing the institutional requirements for the regular publication of a financial stability report also takes a considerable amount of time and thus is not of first order concern. The same holds for the second dimension. Changing a central bank's regulatory or macroprudential tool set takes substantial amounts of time and will not be an immediate response to an interest rate change. Most likely, the third, view-based dimension is the main concern, as the terms included in the press release and the interest rate decision could be determined simultaneously by the same factors (e.g., the presence of financial stability risks). Therefore, as a robustness exercise, in specifications (3) and (4) of Panel I, we let the FSO index enter with a lag of one quarter. Again, while the coefficient becomes smaller than in our baseline specification, it remains significant and the total marginal 
effect is largely similar. ${ }^{38}$

Third, there could also be a general concern that the macro variables, such as the inflation (expectations) gap and the output gap, are contemporaneously affected by the interest rate decision. To address this concern, specifications (5) and (6) of Panel I let both determinants enter with the lag of one quarter as well. Again, the results are very similar to those of our baseline specification. ${ }^{39}$

\subsubsection{Mismeasurement of the Standard Taylor Rule Determinants}

In this section, we address potential concerns that the significant role of financial stability risk measures (and the interaction with our FSO index) in the Taylor rule stems from a mismeasurement of the standard determinants in the Taylor rule, i.e., the measure of inflation (expectations) and the economic slack measure in particular. We start by varying the measure of the inflation expectations gap. In specifications (7) and (8) of Panel I in Table A3, we instead use an OECD measure of yearon-year CPI inflation, without a forward-looking component, that is consistently defined across our sample countries. We again include inflation as a gap measure by subtracting the inflation target from the CPI variable. Some central banks officially target a country-specific definition of inflation rates instead of an inflation measure that is consistently defined across countries. Hence, in specifications (9) and (10) of Panel I, we also include each central bank's respective targeted measure of inflation. In both cases, the results are very similar, and the coefficients on the DFSrisk $\times$ FSO index interaction terms are positive, around the same magnitude as in the baseline specification and highly significant.

Next, we use alternative measures of economic slack. In the absence of a readily available measure of output gaps for our sample of countries at quarterly frequency, we replace our selfconstructed measure of the output gap with a linear interpolation of the annual output gap measure from the OECD to quarterly frequency in specifications (1) and (2) in Panel II. Our self-constructed measure of the output gap was based on a two-sided HP filter and thus has been treated differently than our measures of financial stability risk that were based on a one-sided filter technique. While most of the literature uses a two-sided filter for macro variables, we show in specifications (3) and (4) in Panel II that our results are not affected when the one-sided HP filter approach is also applied to the output gap measure. We also augment our baseline specification with a term for GDP growth, as discussed in Coibion and Gorodnichenko (2012), and present the results in specifications (5) and (6) in Panel II. The results for all six specifications indicate that once again the interaction terms are positive, of similar magnitude to the baseline specification and statistically significant.

Finally, we examine alternative policy goals that central banks might have in their monetary policy decision (i.e., any goals other than stable inflation, a potential output target, and their potential financial stability concerns). The most frequent alternative goal relates to the exchange rate. We therefore include an index of the real effective exchange rate in the baseline specification and present the results in Specification (7) and (8) in Panel II. It turns that the inclusion of a real effective exchange rate index does not change our main result. ${ }^{40}$ Finally, in specifications (9) and

\footnotetext{
${ }^{38}$ The results are very similar when we lag only the third dimension by one quarter.

${ }^{39}$ However, to the extent that this kind of endogeneity were to affect our estimates, it would become less, not more, likely to find positive results. An increase in the policy rate would decrease the inflation and output gaps, and thus bias the coefficients on the macro variables toward zero.

${ }^{40}$ Including the real effective exchange rate as a quarter-on-quarter growth rate leads to an insignificant coefficient on the exchange rate term and does not change our main result. Equally, including corresponding measures of the
} 
(10) in Panel II, we include the early observations for the U.K. and Norway that had been excluded in Section 4.1. To capture the idiosyncratic dynamics of both countries during these periods, we add a simple indicator variable in both cases. While the coefficient is very similar to the one in the baseline specification, we exclude these time periods in the core of the paper because the additional presence of two indicator variables would substantially complicate the construction of meaningful interaction terms.

\subsubsection{Construction of the FSO Index}

This section provides some alternatives for choices that we made when constructing the FSO index. As described in Section 3.2, the third dimension of the index is based on a broad text search of press releases that announce interest rate decisions. In particular, we include a wide range of financial terms in the search, including words like "credit." There might, however, be other reasons that central banks also discuss the development of credit aggregates in normal times, so we provide additional evidence using a third dimension, which we constructed by counting terms related to financial stability and excluding "credit" from the list of search terms. The results are presented in specification (1) and (2) in Panel III. When defining the first dimension of the index, we combined the indicator variable that comes out of the mandate assessment and the indicator variable that is created from publication dates of the financial stability reports into a single dimension. However, by combining the information of both variables, we implicitly make an assumption about the weighting of both indicator variables relative to the other dimensions. We therefore present evidence of what the results would be had we constructed an index with four dimensions. The results of this exercise are depicted in specifications (3) and (4) in Panel III. As can be seen from the coefficients of the interaction terms and the total marginal effects in all cases, the results are very similar to those of the baseline specification and, hence, our choices regarding the index construction are robust to the most plausible alternative.

We also examine the performance of the index in subsamples and in normal times. In specifications (5) and (6) in Panel III, we focus at the early part of the sample by estimating the

specification from 2000Q1 to 2007Q4. In specifications (7) and (8) in Panel III, we only examine the later part of the sample and estimate the specification from 2008Q1 to 2014Q4. Finally, we exclude the period of the global financial crisis from the sample and conduct the estimation from 2000Q1 until 2014Q4 with the exclusion of the period between 2006Q4 and 2010Q1 in specifications (9) and (10) in Panel III. The results of all three sets of specifications are highly supportive of the findings of the baseline specification. In particular, we show that our results hold up in each of the two subsamples with a largely similar magnitude. This suggests that our results are not driven by the sample period we selected. This further suggests that they do not result from dynamics or potential mismeasurement that are unique to the time of the global financial crisis.

\subsubsection{Construction of the Financial Stability Risk Variables}

This section provides supporting evidence for the construction of the financial stability risk measures employed in this paper. We first discuss the role of the backward-looking smoothing procedure we apply to reduce high-frequency fluctuations in the financial stability risk indicators. Until now,

nominal effective exchange rate (i.e., as a level or a growth term) does not change our main result either. 
we have used a backward-looking moving-average that takes into account the current observation and eight lags of the credit-to-GDP gap. To show that selecting this smoothing procedure did not drive our results, we also present the results from using moving-average procedures that use the observations from the last six and the last four quarters in addition to the current observation. We present the results for all specifications contained in Table 3 using the six lag version of the moving-average in Panel II and the four lag version in Panel II of Table A4 of the Appendix. The interaction term is positive and significant in 17 of 20 cases across the two panels, and the total marginal effects for the leaning-type central banks are positive and significant in all 20 cases. This supports the argument that the results are not driven by the smoothing procedure. It should be mentioned, however, that the indicator variable that represents the presence of financial stability risk becomes very volatile in the absence of any smoothing procedure. Given very frequent switches in the financial stability risk indicator, in such a case, it is highly unlikely that central banks would move their policy rates at this high frequency, so a smoothing procedure is clearly preferable if the goal of the analysis is to explain policy rate changes in the real world.

Next, we provide additional evidence regarding the decision to include the real house price gap and the stock price variable in combination with the credit gap variable. Table A5 in the Appendix contains two sets of results that are based on only the real house price gap and only the real equity price gap as measures of financial stability risks. We present the results for the 2,4 , 6 , and 8 percentage points cut-off for the real house price gap and for 5, 10, 15 and 20 percentage cut-off for the real equity price gap. The eight specifications do not contain country fixed effects. ${ }^{41}$ For the real house price gap results in Panel I, we find positive and significant coefficients for the three lower cut-offs and an insignificant result for the highest cut-off. For the real equity price gap in Panel II, we find insignificant results for the three higher cut-offs and negative results for the lowest cut-off. Overall, these results largely mirror those we obtained when relying on the joint financial stability risk measures that included only combinations with the credit-to-GDP gap. However, since it was shown that the presence of a highly positive credit-to-GDP gap is a central variable, the individual inclusion of the real house price and the real equity price gap should not be overstated given that they partially proxy for the credit-to-GDP gap that is not accounted for.

\subsubsection{The Results with Japan}

Finally, we include Japan in the sample and show the results of the key specifications in the paper for the full sample of ten central banks in Table A6 in the Appendix. We focus primarily on the lower cut-off values, where it is more likely that the financial stability risk indicator variable for Japan carries a non-zero value at times. In particular, we present the results for the 2, 4, and 6 percentage point cut-offs in the credit-to-GDP gap (the 8 percentage point cut off was already shown in specification (9) in Table 2), the combinations 2-2, 4-4, and 6-6 for the joint credit-to-GDP and the real house price gap as well as the combinations 2-4, 4-10 and 6-20 for the joint credit-to-GDP and the real equity price gap. We only present specifications with country fixed effects to account for the systematically different nature of Japan in the sample. Starting with the credit-to-GDP gap specifications, the interaction term is positive and significant at the 5- or 10-percent level in all

\footnotetext{
${ }^{41}$ When country fixed effects are included, the results are less clear cut and change in the following way: In the case of the real house price gap, the interaction terms become smaller and are less significant, and in the case of the real equity price gap, the interaction terms become more negative.
} 
three cases. For the combination with the real house price boom measure, the results are somewhat weaker than in the main text because only one of the three specifications has a significant interaction term (however, a second one is marginally insignificant at the 10-percent level). Finally, for the combination with the real equity price boom measure, two out of the three results are insignificant and thus ultimately not much different from those in the main text. Overall, the inclusion of Japan affects the results as expected. However, although the significance levels become lower, the main result, i.e., the presence of a significant difference in the response to financial stability risks across leaning-type and cleaning-type central banks, remains unaffected by the additional inclusion of Japan.

\section{Discussion}

The analysis so far has focused primarily on the effect of financial stability risk on the policy rate. While there is a prominent debate in the academic and the policy worlds on the appropriate degree of leaning (if any), most contributors would still consider the (explicit or implicit) inflation target and, when applicable, an output or employment target, as higher priorities in the medium-term. Engaging in extended periods of leaning to reduce financial stability concerns will, however, affect the outcomes of the macro variables, such as inflation and output, in a disadvantageous way in most circumstances as well.

To get an early idea of the consequences for the macroeconomic outcomes, we evaluate the total marginal effects of the key specifications in our analysis with respect to the macro variables. Table 7 presents the results of this exercise. The table is structured in two panels. The first panel presents the total marginal effects of the output gap and of the inflation gap on interest rates for a representative leaning-type and a representative cleaning-type central bank. The second panel breaks down the results by index dimension. The financial stability risk variables that are used in this table stem from the key specifications in the main text and are selected to be the 4,6 , and 8 percentage point cut-off for the credit-to-GDP gap as well as the 4-4 and the 6-6 percentage point cut-off for the joint credit-to-GDP and the real house price gap.

For the aggregated FSO index in Panel I, we see a significantly positive response by cleaning-type central banks, again defined as central banks at the $25^{\text {th }}$ percentile of the FSO index distribution, to deviations in the output gap as well as deviations in the inflation gap. For leaning-type central banks, however, we see a much more muted response to both macro variables. The strength of the response for leaning-type central banks differs somewhat across fixed effect combinations. Using the results for our baseline specification, i.e., the version with time and country fixed effects, we see a total marginal effect for the output gap that still is positive but substantially less significant. ${ }^{42}$

\footnotetext{
${ }^{42}$ The total marginal effect is significant in only 3 out of the 5 cases (plus one case being marginally insignificant at the 11-percent level.
} 
Table 7: Total Macroeconomic Effects (on Output Gap and Inflation) Estimated by the Taylor Rule with Financial Stability Indicators (FSI) of Credit (C) and Real House Price (HP) Gap Indicators, 2000Q1-2014Q4

\begin{tabular}{|c|c|c|c|c|c|c|c|c|c|c|}
\hline & \multicolumn{2}{|c|}{ Credit (4pp) } & \multicolumn{2}{|c|}{ Credit (6pp) } & \multicolumn{2}{|c|}{ Credit (8pp) } & \multicolumn{2}{|c|}{$\mathrm{C}(4 \mathrm{pp}) \& \mathrm{HP}(4 \mathrm{pp})$} & \multicolumn{2}{|c|}{ C (6pp) \& HP (6pp) } \\
\hline & (1) & $(2)$ & (3) & $(4)$ & $(5)$ & (6) & $(7)$ & $(8)$ & (9) & $(10)$ \\
\hline \multicolumn{11}{|l|}{ Panel I: Total FSO Index } \\
\hline Total O.Gap effect, 25pctl & $0.181^{* *}$ & $0.288^{* * *}$ & $0.182^{* *}$ & $0.302^{* * *}$ & $0.240^{* * *}$ & $0.308^{* * *}$ & $0.231^{* * *}$ & $0.304^{* * *}$ & $0.252^{* * *}$ & $0.311^{* * *}$ \\
\hline p-value & 0.02 & 0.00 & 0.02 & 0.00 & 0.00 & 0.00 & 0.00 & 0.00 & 0.00 & 0.00 \\
\hline Total O.Gap Effect, 75pctl & 0.052 & 0.067 & 0.076 & $0.080^{*}$ & 0.076 & $0.076^{*}$ & -0.021 & 0.049 & 0.029 & $0.070^{*}$ \\
\hline p-value & 0.50 & 0.11 & 0.33 & 0.06 & 0.33 & 0.07 & 0.77 & 0.25 & 0.71 & 0.09 \\
\hline Total Inf. Effect, 25pctl & $1.466^{* * *}$ & $0.380^{* * *}$ & $1.460^{* * *}$ & $0.345^{* * *}$ & $1.380^{* * *}$ & $0.291^{* *}$ & $1.391^{* * *}$ & $0.331^{* * *}$ & $1.396^{* * *}$ & $0.264^{* *}$ \\
\hline p-value & 0.00 & 0.00 & 0.00 & 0.00 & 0.00 & 0.01 & 0.00 & 0.00 & 0.00 & 0.02 \\
\hline Total Inf. Effect, 75pctl & $0.834^{* * *}$ & 0.048 & $0.836^{* * *}$ & 0.013 & $0.837^{* * *}$ & -0.039 & $0.904^{* * *}$ & 0.044 & $0.899^{* * *}$ & -0.024 \\
\hline p-value & 0.00 & 0.62 & 0.00 & 0.90 & 0.00 & 0.69 & 0.00 & 0.65 & 0.00 & 0.81 \\
\hline \multicolumn{11}{|c|}{ Panel II: Individual Index Dimensions } \\
\hline \multicolumn{11}{|l|}{ Statutory Dimension } \\
\hline Total O.Gap Effect, 25pctl & 0.086 & $0.143^{* * *}$ & 0.062 & $0.146^{* * *}$ & 0.081 & $0.142^{* * *}$ & 0.087 & $0.150 * * *$ & 0.104 & $0.155^{* * *}$ \\
\hline Total O.Gap Effect, 75pctl & 0.099 & 0.029 & 0.161 & 0.040 & 0.109 & 0.022 & 0.042 & -0.009 & 0.076 & 0.015 \\
\hline Total Inf. Effect, 25pctl & $1.199^{* * *}$ & $0.256^{* *}$ & $1.228^{* * *}$ & $0.250^{* *}$ & $1.179^{* * *}$ & $0.215^{*}$ & $1.240^{* * *}$ & $0.253^{* *}$ & $1.316^{* * *}$ & $0.255^{* *}$ \\
\hline Total Inf. Effect, 75pctl & $0.873^{* * *}$ & -0.028 & $0.904^{* * *}$ & -0.032 & $0.897^{* * *}$ & -0.056 & $0.939^{* * *}$ & -0.011 & $1.028^{* * *}$ & 0.000 \\
\hline \multicolumn{11}{|l|}{ Regulatory Dimension } \\
\hline Total O.Gap Effect, 25pctl & $0.181^{* *}$ & $0.244^{* * *}$ & $0.180^{* *}$ & $0.265^{* * *}$ & $0.224^{* * *}$ & $0.255^{* * *}$ & $0.190^{* *}$ & $0.239 * * *$ & $0.196^{* *}$ & $0.272^{* * *}$ \\
\hline Total O.Gap Effect, 75pctl & 0.035 & $0.078^{*}$ & 0.056 & $0.089^{*}$ & 0.090 & $0.107^{* *}$ & -0.001 & 0.073 & 0.026 & $0.085^{*}$ \\
\hline Total Inf. Effect, 25pctl & $0.967^{* * *}$ & $0.196^{* *}$ & $0.988^{* * *}$ & 0.140 & $0.995^{* * *}$ & 0.085 & $0.952^{* * *}$ & 0.158 & $1.000^{* * *}$ & 0.111 \\
\hline Total Inf. Effect, 75pctl & $0.853^{* * *}$ & $0.245^{* *}$ & $0.883^{* * *}$ & 0.172 & $0.928^{* * *}$ & 0.160 & $0.888^{* * *}$ & $0.216^{*}$ & $0.901^{* * *}$ & 0.119 \\
\hline \multicolumn{11}{|l|}{ View-Based Dimension } \\
\hline Total O.Gap Effect, 25pctl & $0.154^{*}$ & $0.248^{* * *}$ & 0.131 & $0.235^{* * *}$ & $0.163^{*}$ & $0.244^{* * *}$ & 0.125 & $0.220 * * *$ & 0.127 & $0.221^{* * *}$ \\
\hline Total O.Gap Effect, 75pctl & 0.095 & $0.154^{* * *}$ & 0.090 & $0.151^{* * *}$ & 0.085 & $0.148^{* * *}$ & 0.053 & $0.141^{* * *}$ & 0.077 & $0.138^{* * *}$ \\
\hline Total Inf. Effect, 25pctl & $1.017^{* * *}$ & $0.221^{*}$ & $1.028^{* * *}$ & 0.184 & $1.064^{* * *}$ & 0.198 & $1.072^{* * *}$ & $0.225^{*}$ & $1.052^{* * *}$ & 0.171 \\
\hline Total Inf. Effect, 75pctl & $1.085^{* * *}$ & 0.159 & $1.077^{* * *}$ & 0.115 & $1.102^{* * *}$ & 0.122 & $1.064^{* * *}$ & 0.151 & $1.064^{* * *}$ & 0.110 \\
\hline Macro Variables & Yes & Yes & Yes & Yes & Yes & Yes & Yes & Yes & Yes & Yes \\
\hline FSI, Index and Interaction & Yes & Yes & Yes & Yes & Yes & Yes & Yes & Yes & Yes & Yes \\
\hline Time Fixed Effects & Yes & Yes & Yes & Yes & Yes & Yes & Yes & Yes & Yes & Yes \\
\hline Country Fixed Effects & No & Yes & No & Yes & No & Yes & No & Yes & No & Yes \\
\hline $\mathrm{N}$ & 500 & 500 & 500 & 500 & 500 & 500 & 500 & 500 & 500 & 500 \\
\hline Countries & 9 & 9 & 9 & 9 & 9 & 9 & 9 & 9 & 9 & 9 \\
\hline
\end{tabular}

The financial stability indicators reflect measures that are smoothed over 8 lags and the contemporaneous value of the credit and real house price gaps. $\mathrm{R}^{2}$ values are from 0.65 to 0.70 for specifications without country fixed effects, and from 0.87 to 0.89 for those with country fixed effects. All specifications include a constant. ${ }^{*} p<0.10,{ }^{* *} p<0.05,{ }^{* * *} p<0.01$ 
For the inflation expectations gap, we observe a positive and significant effect, which is, however, lower than the one for the representative leaning-type central bank, only for the specifications without country fixed effects. Overall, this exercise shows that there could be potentially a cost in the form of deviating more from the inflation an/or output target - associated with the use of the policy rate in address financial stability concerns.

However, it should be mentioned that the results in this analysis are obtained from a crosscountry panel using a harmonized measure of inflation expectations and a harmonized measure of the output gap. Further, our analysis does not take into account differences in national mandates with respect to a potential inflation and output. There are significant differences in the way the inflation target is formulated. While the inflation target in Canada is symmetric around 2 percent, for example, the target for the ECB is one-sided and inflation should stay slightly below the 2percent value.

At the same time, some central banks, such as the Federal Reserve, have a clear mandate to improve output/employment growth as well, while others, such as the ECB, focus only on their inflation target. Hence, even though our FSO index identifies a central bank as a representative leaning-type, it is quite possible that it obtains larger coefficients on the macro variables once the Taylor rule is estimated at the country-level, using more detailed information that cannot be consistently exploited in a panel setting. Turning next to the disaggregated FSO index in Panel II, we see that the results for the aggregated index are confirmed and largely reappear across all three dimensions of the index.

Finally, we approach the question from a different angle and compare the actual outcomes of the macro variables across the observations of both leaning-type and cleaning-type central banks. Table 8 presents simple summary statistics for different output gap measures for the two groups and the deviation of several inflation concepts from the individual inflation target. Related to the distribution values in the main text, the cleaning-type averages are computed based on all countryquarter observations below the $25^{\text {th }}$ percentile, and the leaning-type averages are computed based on all observations above the $75^{\text {th }}$ percentile. However, throughout the remainder of this section, the reported numbers are only unconditional summary statistics, and it is not possible to ascertain the ultimate cause of these differences. ${ }^{43}$

The memo panel in the bottom of the table presents the values of the FSO index as well as the value of its individual components for both groups of observations. For the aggregated version of the index, these values amount to 2.02 for leaning-type central banks and to 0.67 for cleaning-type central banks. We also present the summary statistics for the main financial stability risk variable and the policy interest rates in both groups of observations. ${ }^{44}$

\footnotetext{
${ }^{43}$ Both output and inflation are subject to influences other than the policy rate. In particular, small open economies can experience strong spillovers from abroad, resulting in higher pressures for both variables to deviate from target.

${ }^{44}$ The policy rate for the low index value observation amounts to 3.53 , and the policy rate for the high-index value observations amounts to 1.97. At first glance, these numbers seem somewhat suprising because leaning-type central banks are expected to have ceteris paribus higher interest rates than cleaning-type central banks. However, a key driver of this difference is the simple fact that low values of the FSO index are more prominently located at the beginning of the sample - a period during which interest rates were high in general and for reasons other than financial stability concerns (e.g., inflation concerns). Hence, the importance of the ceteris paribus notion in the statement should not be understated. To abstract in the comparison of policy rates between both groups from the time effects, we display a time-adjusted policy rate in the last row of the table. This policy rate has been constructed by subtracting the average value of the policy rate across countries in each quarter, calculated from all
} 
Table 8: Summary Statistics over Observations Included in Baseline Specification, at High and Low FSO Index Values (2000Q1-2014Q4)

\begin{tabular}{|c|c|c|c|c|c|}
\hline & \multicolumn{2}{|c|}{$\begin{array}{c}\text { FSO Index }<25^{\text {th }} \text { Percentile } \\
\qquad(\mathrm{N}=125)\end{array}$} & \multicolumn{2}{|c|}{$\begin{array}{c}\text { FSO Index }>75^{\text {th }} \text { Percentile } \\
\qquad(\mathrm{N}=119)\end{array}$} & \multirow[t]{2}{*}{$\begin{array}{l}\text { Difference } \\
\text { of Means }\end{array}$} \\
\hline & Mean & Std. Dev. & Mean & Std. Dev. & \\
\hline \multicolumn{6}{|l|}{ Macroeconomic Outcomes } \\
\hline \multicolumn{6}{|l|}{ Output Gap } \\
\hline Output Gap, 2-sided HP filter (\%) & 0.29 & 1.14 & -0.22 & 1.43 & -0.51 \\
\hline OECD Output Gap (\%) & 0.45 & 2.13 & -0.41 & 1.93 & -0.86 \\
\hline Output Gap, 1-sided HP filter (\%) & 0.11 & 1.07 & -0.34 & 1.64 & -0.45 \\
\hline \multicolumn{6}{|l|}{ Inflation Deviation from Target $(\mathrm{pp})^{\mathrm{a}}$} \\
\hline 1-yr CPI Inflation Expectations & 0.25 & 0.63 & -0.23 & 0.93 & -0.48 \\
\hline CPI Inflation & 0.43 & 1.09 & -0.23 & 1.19 & -0.66 \\
\hline National Headline Inflation & 0.26 & 0.98 & -0.18 & 1.25 & -0.44 \\
\hline \multicolumn{6}{|l|}{ Memo } \\
\hline Total FSO Index & 0.67 & 0.34 & 2.02 & 0.15 & 1.35 \\
\hline Statutory Dimension & 0.17 & 0.28 & 0.82 & 0.24 & 0.65 \\
\hline Regulatory Dimension & 0.43 & 0.36 & 0.87 & 0.24 & 0.44 \\
\hline View-Based Dimension & 0.07 & 0.10 & 0.33 & 0.23 & 0.27 \\
\hline Credit Gap, ${ }^{\mathrm{b}}$ 8pp cut-off & 0.09 & 0.28 & 0.33 & 0.47 & 0.24 \\
\hline Policy Rate (pp) & 3.53 & 2.47 & 1.97 & 1.80 & -1.56 \\
\hline Time-Adjusted Policy Rate $(\mathrm{pp})^{\mathrm{c}}$ & 0.23 & 1.79 & -0.23 & 1.59 & -0.46 \\
\hline
\end{tabular}

(a) When applicable, the inflation target is defined as the midpoint of the target range or the upper bound of an asymmetric target. (b) The credit gap indicator is calculated from a gap measure smoothed over the contemporaneous value and 8 lags. (c) Calculated as the policy rate less the quarter-specific average of policy rates across all sample countries. Summary statistics are calculated over a sample of 9 countries.

We then turn to a comparison of the mean values for the macro variables. The first set of variables comprises three different measures of the output gap. ${ }^{45}$ In all three cases the mean of the output gap measure for cleaning-type country-time observations is more positive than the mean of the output gap measure for leaning-type country-time observations. The differences range between 0.45 and 0.86 percentage points. However, this difference cannot necessarily be attributed to differences in the response to financial stability risks across central banks and over time. The second set of variables comprises three different measures of deviations from the inflation target. ${ }^{46}$ When the means of the inflation deviations between the two groups are compared, the means for

sample observations. As suspected, the initial difference of 1.56 between the policy rates in both groups reduces to 0.46 in the time-adjusted version and thus supports the previous interpretation. To eliminate (and reverse) the remaining difference, we would also have to control for inflation and output performance.

${ }^{45}$ The first measure was used in the baseline specification and the other two measures in the robustness section, i.e., the annual output gap from the OECD that has been extrapolated to quarterly frequency as well as the one that we constructed using a one-sided filter technique.

${ }^{46}$ The first variable was used in the baseline specification and is based on inflation expectations, the second measure is the CPI index obtained from the OECD that is consistently defined across countries, and the last variable is the country-specific measure of headline inflation, obtained from national sources. 
the cleaning-type country-time observations are more positive than the country-time observations of the leaning-type group. The differences in the means range between 0.44 and 0.66 percentage points. These differences should not be overinterpreted because many other factors could play a role, and we only can identify correlations. For instance, the pre-2008 global financial crisis period was characterized by less concern about financial stability and featured higher growth, higher inflation and higher interest rates, and likely had fewer leaning-type observations compared with the post2008 period. Indeed, the evidence illustrated here indicates that cleaning-type central banks have, on average, higher inflation rates and more positive output gaps than leaning-type central banks - a pattern that is at least consistent with a ceteris paribus higher policy rate relative to the economic and financial fundamentals facing the leaning-type central banks.

Eventually, in a formal welfare evaluation, the costs of leaning, i.e., deviating from the macro targets (identified in a more thorough way), will have to be weighed against the benefits of reducing the expected output loss that accompanies a financial crisis. To calculate such an expected value, it is important to have a good idea of the size of the expected output loss of a crisis scenario relative to a situation when there is no crisis but a higher interest rate potentially taxes the economy and, in particular, economic growth. At the same time, there is a need for a reliable estimate of the likelihood of a financial crisis both when central banks have a policy response and when they do not. The latter exercise is not straightforward, however, because estimating crisis probabilities based on past data realizations might not consider the higher degree of financial interconnectedness that we experience today relative to the past and, furthermore, may abstract from accounting for the central bank's policy stance before a crisis and especially before a non-crisis situation, respectively. Overall, more research in this direction is necessary.

\section{Conclusion}

In this paper, we have analyzed the institutional and operational frameworks of central banks in ten major advanced economies and examined to what extent monetary policy decisions incorporate financial stability concerns. First, based on the literature on the interaction of monetary policy and financial stability, we have constructed a time-varying financial stability orientation index to measure the institutional capacity and possible intentions of ten central banks to account for financial stability risks in their monetary policy decisions. Second, we have included this index in a cross-country panel of Taylor rules over the period from 2000Q1 to 2014Q4 and thus allowed for a heterogeneous response of central banks' monetary policy rates to financial stability risks.

We find that in episodes of high financial stability risks, measured by high values in the creditto-GDP gap, leaning-type central banks, i.e., those with a high FSO index value at a given point in time, appear to take financial stability considerations into account in their monetary policy rate decisions, while we do not find such effects for cleaning-type central banks. Our baseline specification suggests that a representative leaning-type central bank's policy rate is about 0.3 percentage points higher than the policy rate of a representative cleaning-type central bank in the presence of financial stability risks. A variation of this specification that does not control for country-specific factors finds that this difference rises to 0.7 percentage points. Even the lower estimate of 0.3 percentage points represents about 11 percent of the average policy interest rate across the ten 
countries studied here from 2000Q1 to 2014Q4, which could have a significant economic impact when maintained over a long period of elevated financial stability risk. We also find that the strength of this response increases in the additional presence of a house price boom but not so for the simultaneous occurrence of an equity price boom.

Our simple comparisons of average macroeconomic outcomes between central banks with a high and low financial stability orientation suggest that there may be both inflation costs and output costs associated with a high financial stability orientation. In particular, central banks with a high financial stability orientation show, on average, a weaker response to deviations in output and inflation than those with a low financial stability orientation, as well as lower inflation rates and growth rates. However, further analysis is required to identify how much of these outcome differences can be attributed to the central banks' financial stability orientation and actual leaning behavior, after accounting for country-specific economic conditions. A more sophisticated cost-benefit analysis would also include a quantification of the benefits associated with avoiding a financial crisis through leaning. Finally, such future work should also include a consideration of different possible weighting schemes to compare the potential social costs and benefits.

Overall, it will be interesting to see how the financial stability orientation of central banks develops in the future. Will there be a change in the paradigm of monetary policy that advocates more leaning behavior in light of the unique experience of the 2008 global financial crisis as advocated by the BIS, for example? Or is the current experience only the first-round response by central banks to rebounding financial stability concerns and once central banks are equipped with sufficient macroprudential tools, will the main focus of monetary policy revert to traditional inflation and output gap considerations?

\section{References}

Ajello, A., Laubach, T. , Lopez-Salido, D., Nakat, T., 2015. "Financial Stability and Optimal Interest Rate Policy," Federal Reserve Board, mimeo.

Alpanda, S., Zubairy, S., 2014. "Addressing Household Indebtedness: Monetary, Fiscal or Macroprudential Policy?," Bank of Canada Working Papers 14-58.

Angeloni, I., Faia, E., Winkler, R., 2014. "Exit Strategies," European Economic Review, 70(C), p. 231-257.

Bank of Canada, 2011. "Renewal of the Inflation Target: Background Information - November 2011."

Basant Roi, M., Mendes, R., 2007. "Should Central Banks Adjust Their Target Horizons in Response to House-Price Bubbles?" Discussion Papers 07-4, Bank of Canada.

Bernanke, B., Gertler, M., 1999. "Monetary Policy and Asset Price Volatility," Economic Review, Federal Reserve Bank of Kansas City, Q IV, p. 17-51. 
Bernanke, B., Gertler, M., 2001. "Should Central Banks Respond to Movements in Asset Prices?" American Economic Review Papers and Proceedings, 91, p. 253-257.

Bank for International Settlements (BIS), 2010. "Guidance for National Authorities Operating the Countercyclical Capital Buffer." Downloadable at http://www.bis.org/publ/bcbs187.pdf.

Bauer, G., 2015. "International House Price Cycles, Monetary Policy and Risk Premiums," Bank of Canada Working Paper 2014-54.

Borio, C., Zhu, H., 2012. "Capital Regulation, Risk-Taking and Monetary Policy: A Missing Link in the Transmission Mechanism?" Journal of Financial Stability, 8(4), p. 236-251.

Brunnermeier, M.K., Sannikov, Y., 2014. "Monetary Analysis: Price and Financial Stability," ECB Forum On Central Banking, Sintra, Portugal, In Press, Print.

Christensen, I., Meh, C., 2011. "Countercyclical Loan-to-Value Ratios and Monetary Policy," mimeo.

Christiano, L., Ilut, C., Motto, R., Rostagno, M., 2010. "Monetary Policy and Stock Market Booms," Proceedings - Economic Policy Symposium - Jackson Hole, Federal Reserve Bank of Kansas City, p.85-145.

Coibion, O., Gorodnichenko, Y., 2012. "Why Are Target Interest Rate Changes So Persistent?" American Economic Journal: Macroeconomics, American Economic Association, 4(4), p. 126-62.

Collard, F., Dellas, H., Diba, B., Loisel, O., 2012. "Optimal Monetary and Prudential Policies," Banque de France Working Paper 413.

Curdia, V., Woodford, M., 2009. "Credit Frictions and Optimal Monetary Policy," BIS Working Papers 278.

Curdia, V., Woodford, M., 2010. "Credit Spreads and Monetary Policy," Journal of Money, Credit and Banking, 42(s1), p. 3-35, 09.

Drehmann, M., Borio, C., Gambacorta, L., Jimnez, G., Trucharte, C., 2010. "Countercyclical Capital Buffers: Exploring Options," BIS Working Papers 317.

Drehmann, M., Borio, C., Tsatsaronis, K., 2011. "Anchoring Countercyclical Capital Buffers: The Role of Credit Aggregates," BIS Working Papers 355.

Gambacorta, L., Signoretti, F., 2014. "Should Monetary Policy Lean Against the Wind?" Journal of Economic Dynamics and Control, 43(C), p. 146-174.

Garriga, C., Kydland, F., Šustek, R., 2013. "Mortgages and Monetary Policy," Working Papers 2013-37, Federal Reserve Bank of St. Louis. 
Gelain, P., Lansing, K., Mendicino, C., 2013. "House Prices, Credit Growth, and Excess Volatility: Implications for Monetary and Macroprudential Policy," International Journal of Central Banking, 9(2), p. 219-276.

Gilchrist, S., Leahy, J. V., 2002. "Monetary Policy and Asset Prices," Journal of Monetary Economics, 49(1), p. 75-97.

Iacoviello, M., 2005. "House Prices, Borrowing Constraints, and Monetary Policy in the Business Cycle," American Economic Review, 95(3), p. 739-764.

International Monetary Fund (IMF), 2013. The Interaction of Monetary and Macroprudential Policies.

Jordà, Ò., Schularick, P., Taylor, A.M., 2015. "Leveraged Bubbles," NBER Working Papers 21486.

Kannan, P., Rabanal, P., Alasdair, S.M., 2012. "Monetary and Macroprudential Policy Rules in a Model with House Price Booms," The B.E. Journal of Macroeconomics, 12(1), p. 1-44.

Kocherlakota, N. 2014. "Monetary Policy and Financial Stability," International Research Forum on Monetary Policy, hosted by the Board of Governors of the Federal Reserve System in Washington DC, Mar. 27, 2014.

Leeper, E.M., Nason, J.M., 2014. "Bringing Financial Stability Into Monetary Policy," Centre for Applied Macroeconomic Analysis Working Paper 72/2014.

Loisel, O., 2014. Discussion of Quint, D., Rabanal, P., 2014. "Monetary and Macroprudential Policy in an Estimated DSGE Model of the Euro Area," International Journal of Central Banking, 10(2), p. 169-236.

Oet, M.V., Ong, S., Dooley, J.M., 2015. "Does Financial Stability Matter to the Fed?" Federal Reserve Bank of Cleveland, mimeo.

Orphanides, A., 2001. "Monetary Policy Rules Based on Real-Time Data," American Economic Review, American Economic Association, vol. 91(4), pages 964-985.

Peek, J., Rosengren, E.S., Tootell, G.M.B., 2015. "Should U.S. Monetary Policy Have a Ternary Mandate?" Federal Reserve Bank of Boston, mimeo. Downloadable at http://www.bostonfed.org/ macroprudential2015/papers/Rosengren-Peek-Tootell.pdf.

Rubio, M., 2011. "Fixed and Variable Rate Mortgages, Business Cycles, and Monetary Policy," Journal of Money, Credit and Banking, 43(4), pages 657-688, 06.

Rubio, M., Carrasco-Gallego, J. A., 2015. "Macroprudential and Monetary Policy Rules: A Welfare Analysis," The Manchester School, 83, p. 127-152.

Smets, F., 2014. "Financial Stability and Monetary Policy: How Closely Interlinked?," International Journal of Central Banking, 10(2), p. 263-300. 
Svensson, L.E.O., 2013. "Leaning Against the Wind' Leads to a Higher (Not Lower) Household Debt-to-GDP Ratio," mimeo. Downloadable at http://larseosvensson.se/files/papers/Leaningagainst-the-wind-leads-to-higher-household-debt-to-gdp-ratio.pdf.

Svenssson, L.E.O., 2014. "Inflation Targeting and Leaning against the Wind," International Journal of Central Banking, 10(2), p. 103-113.

Woodford, M. 2012. "Inflation Targeting and Financial Stability," Svergies Riksbank: Economic Review, 1, p.7-32. 


\section{Appendix}

\subsection{Additional Tables and Figures}

\subsubsection{Additional Tables}

Table A1: Annual Averages of Individual FSO Index Dimensions

\begin{tabular}{|c|c|c|c|c|c|c|c|c|c|c|c|c|c|c|c|}
\hline & 2000 & 2001 & 2002 & 2003 & 2004 & 2005 & 2006 & 2007 & 2008 & 2009 & 2010 & 2011 & 2012 & 2013 & 2014 \\
\hline \multicolumn{16}{|c|}{ Statutory Dimension } \\
\hline Australia & 0.00 & 0.00 & 0.00 & 0.00 & 0.50 & 0.50 & 0.50 & 0.50 & 0.50 & 0.50 & 0.50 & 0.50 & 0.50 & 0.50 & 0.50 \\
\hline Canada & 0.00 & 0.00 & 0.13 & 0.50 & 0.50 & 0.50 & 0.50 & 0.50 & 0.50 & 0.50 & 0.50 & 0.50 & 0.50 & 0.50 & 0.50 \\
\hline Japan & 0.50 & 0.50 & 0.50 & 0.50 & 0.50 & 0.75 & 1.00 & 1.00 & 1.00 & 1.00 & 1.00 & 1.00 & 1.00 & 1.00 & 1.00 \\
\hline Euro area & 0.50 & 0.50 & 0.50 & 0.50 & 0.63 & 1.00 & 1.00 & 1.00 & 1.00 & 1.00 & 1.00 & 1.00 & 1.00 & 1.00 & 1.00 \\
\hline New Zealand & 0.00 & 0.00 & 0.00 & 0.00 & 0.13 & 0.50 & 0.50 & 0.50 & 0.75 & 1.00 & 1.00 & 1.00 & 1.00 & 1.00 & 1.00 \\
\hline Norway & 0.50 & 0.50 & 0.50 & 0.50 & 0.50 & 0.50 & 0.50 & 0.50 & 0.50 & 0.50 & 0.50 & 0.50 & 0.50 & 0.50 & 0.50 \\
\hline Sweden & 0.50 & 0.50 & 0.50 & 0.50 & 0.50 & 0.50 & 0.50 & 0.50 & 0.50 & 0.50 & 0.50 & 0.50 & 0.50 & 0.50 & 0.50 \\
\hline Switzerland & 0.00 & 0.00 & 0.00 & 0.50 & 1.00 & 1.00 & 1.00 & 1.00 & 1.00 & 1.00 & 1.00 & 1.00 & 1.00 & 1.00 & 1.00 \\
\hline United Kingdom & 0.50 & 0.50 & 0.50 & 0.50 & 0.50 & 0.50 & 0.50 & 0.50 & 0.50 & 1.00 & 1.00 & 1.00 & 1.00 & 1.00 & 1.00 \\
\hline United States & 0.00 & 0.00 & 0.00 & 0.00 & 0.00 & 0.00 & 0.00 & 0.00 & 0.00 & 0.00 & 0.00 & 0.13 & 0.25 & 0.25 & 0.25 \\
\hline \multicolumn{16}{|c|}{ Regulatory Dimension } \\
\hline Australia & 1.00 & 1.00 & 1.00 & 1.00 & 1.00 & 1.00 & 1.00 & 1.00 & 1.00 & 1.00 & 1.00 & 1.00 & 1.00 & 1.00 & 1.00 \\
\hline Canada & 1.00 & 1.00 & 1.00 & 1.00 & 1.00 & 1.00 & 1.00 & 1.00 & 1.00 & 1.00 & 1.00 & 1.00 & 1.00 & 1.00 & 1.00 \\
\hline Japan & 1.00 & 1.00 & 1.00 & 1.00 & 1.00 & 1.00 & 1.00 & 1.00 & 1.00 & 1.00 & 1.00 & 1.00 & 1.00 & 1.00 & 1.00 \\
\hline Euro area & 0.50 & 0.50 & 0.50 & 0.50 & 0.50 & 0.50 & 0.50 & 0.50 & 0.50 & 0.50 & 0.50 & 0.50 & 0.50 & 0.50 & 0.50 \\
\hline New Zealand & 0.00 & 0.00 & 0.00 & 0.00 & 0.00 & 0.00 & 0.00 & 0.00 & 0.00 & 0.00 & 0.00 & 0.00 & 0.00 & 0.00 & 0.00 \\
\hline Norway & 1.00 & 1.00 & 1.00 & 1.00 & 1.00 & 1.00 & 1.00 & 1.00 & 1.00 & 1.00 & 1.00 & 1.00 & 1.00 & 0.63 & 0.50 \\
\hline Sweden & 1.00 & 1.00 & 1.00 & 1.00 & 1.00 & 1.00 & 1.00 & 1.00 & 1.00 & 1.00 & 1.00 & 1.00 & 1.00 & 1.00 & 1.00 \\
\hline Switzerland & 1.00 & 1.00 & 1.00 & 1.00 & 1.00 & 1.00 & 1.00 & 1.00 & 1.00 & 1.00 & 1.00 & 0.50 & 0.50 & 0.50 & 0.50 \\
\hline United Kingdom & 1.00 & 1.00 & 1.00 & 1.00 & 1.00 & 1.00 & 1.00 & 1.00 & 1.00 & 1.00 & 1.00 & 1.00 & 1.00 & 0.25 & 0.00 \\
\hline United States & 0.50 & 0.50 & 0.50 & 0.50 & 0.50 & 0.50 & 0.50 & 0.50 & 0.50 & 0.50 & 0.50 & 0.50 & 0.50 & 0.50 & 0.50 \\
\hline \multicolumn{16}{|c|}{ View-Based Dimension } \\
\hline Australia & 0.20 & 0.14 & 0.31 & 0.40 & 0.25 & 0.22 & 0.32 & 0.22 & 0.39 & 0.73 & 0.56 & 0.34 & 0.29 & 0.41 & 0.35 \\
\hline Canada & 0.02 & 0.00 & 0.10 & 0.02 & 0.01 & 0.00 & 0.12 & 0.16 & 0.33 & 0.31 & 0.13 & 0.24 & 0.29 & 0.20 & 0.24 \\
\hline Japan & 0.45 & 0.66 & 0.88 & 0.56 & 0.93 & 0.84 & 0.30 & 0.48 & 0.49 & 0.97 & 0.81 & 0.94 & 0.91 & 0.55 & 0.38 \\
\hline Euro area & 0.14 & 0.06 & 0.12 & 0.11 & 0.10 & 0.06 & 0.12 & 0.31 & 0.26 & 0.37 & 0.35 & 0.30 & 0.58 & 0.46 & 0.45 \\
\hline New Zealand & 0.02 & 0.03 & 0.04 & 0.04 & 0.01 & 0.05 & 0.03 & 0.08 & 0.19 & 0.79 & 0.32 & 0.18 & 0.13 & 0.42 & 0.13 \\
\hline Norway & 0.12 & 0.08 & 0.12 & 0.10 & 0.09 & 0.11 & 0.13 & 0.17 & 0.23 & 0.12 & 0.31 & 0.42 & 0.16 & 0.30 & 0.09 \\
\hline Sweden & 0.00 & 0.01 & 0.06 & 0.03 & 0.00 & 0.05 & 0.09 & 0.26 & 0.24 & 0.20 & 0.16 & 0.04 & 0.10 & 0.17 & 0.16 \\
\hline Switzerland & 0.00 & 0.01 & 0.00 & 0.01 & 0.01 & 0.00 & 0.00 & 0.13 & 0.20 & 0.13 & 0.08 & 0.10 & 0.33 & 0.24 & 0.05 \\
\hline United Kingdom & 0.07 & 0.17 & 0.29 & 0.21 & 0.13 & 0.10 & 0.11 & 0.24 & 0.16 & 0.30 & 0.12 & 0.08 & 0.13 & 0.16 & 0.18 \\
\hline United States & 0.22 & 0.07 & 0.04 & 0.05 & 0.00 & 0.00 & 0.00 & 0.20 & 0.47 & 0.97 & 0.36 & 0.07 & 0.16 & 0.16 & 0.09 \\
\hline
\end{tabular}


Table A2: Summary Statistics over Observations in the Baseline Specification (2000Q1-2014Q4)

\begin{tabular}{|c|c|c|c|c|}
\hline & Mean & Std. Dev. & Min. & Max. \\
\hline Policy Rate (pp) & 2.72 & 2.04 & -0.08 & 8.25 \\
\hline \multicolumn{5}{|l|}{ Macroeconomic Variables } \\
\hline Output Gap (\%) & 0.00 & 1.32 & -5.19 & 4.02 \\
\hline OECD Output Gap (\%) & 0.06 & 1.88 & -4.77 & 4.84 \\
\hline Output Gap, 1-sided HP filter (\%) & -0.12 & 1.35 & -6.63 & 2.67 \\
\hline \multicolumn{5}{|l|}{ Inflation Deviation from Target $(\mathrm{pp})^{\mathrm{a}}$} \\
\hline 1-yr CPI Inflation Expectations & -0.09 & 0.81 & -2.57 & 2.31 \\
\hline CPI Inflation & -0.15 & 1.22 & -3.90 & 3.60 \\
\hline National Headline Inflation & -0.15 & 1.18 & -3.90 & 3.63 \\
\hline \multicolumn{5}{|l|}{ Financial Stability Orientation (FSO) Index } \\
\hline Total FSO Index & 1.44 & 0.53 & 0 & 2.5 \\
\hline Statutory Dimension & 0.52 & 0.35 & 0 & 1 \\
\hline Regulatory Dimension & 0.73 & 0.36 & 0 & 1 \\
\hline View-Based Dimension & 0.18 & 0.20 & 0 & 1 \\
\hline Total FSO Index including Japan ${ }^{\mathrm{b}}$ & 1.55 & 0.61 & 0 & 3 \\
\hline \multicolumn{5}{|l|}{ Financial Stability Indicators ${ }^{c}$} \\
\hline Credit Gap, 2pp cut-off & 0.65 & 0.48 & 0 & 1 \\
\hline Credit Gap, 4pp cut-off & 0.60 & 0.49 & 0 & 1 \\
\hline Credit Gap, 6pp cut-off & 0.45 & 0.50 & 0 & 1 \\
\hline Credit Gap, 8pp cut-off & 0.30 & 0.46 & 0 & 1 \\
\hline Credit Gap, 10pp cut-off & 0.20 & 0.40 & 0 & 1 \\
\hline Credit Gap, 12pp cut-off & 0.12 & 0.33 & 0 & 1 \\
\hline Real House Price Gap, 2pp cut-off & 0.72 & 0.45 & 0 & 1 \\
\hline Real House Price Gap, 4pp cut-off & 0.67 & 0.47 & 0 & 1 \\
\hline Real House Price Gap, 6pp cut-off & 0.57 & 0.50 & 0 & 1 \\
\hline Real House Price Gap, 8pp cut-off & 0.46 & 0.50 & 0 & 1 \\
\hline Real Equity Price Gap, 5pp cut-off & 0.28 & 0.45 & 0 & 1 \\
\hline Real Equity Price Gap, 10pp cut-off & 0.23 & 0.42 & 0 & 1 \\
\hline Real Equity Price Gap, 15pp cut-off & 0.18 & 0.38 & 0 & 1 \\
\hline Real Equity Price Gap, 20pp cut-off & 0.14 & 0.35 & 0 & 1 \\
\hline Credit Gap (4pp) \& House Price Gap (4pp) & 0.49 & 0.50 & 0 & 1 \\
\hline Credit Gap (6pp) \& House Price Gap (6pp) & 0.33 & 0.47 & 0 & 1 \\
\hline \multicolumn{5}{|l|}{ Memo — Financial Stability Variables } \\
\hline Credit (\%GDP) & 169.49 & 27.91 & 108.29 & 247.73 \\
\hline Real House Price Index $(100=2005)$ & 103.63 & 18.77 & 60.03 & 146.71 \\
\hline Real Stock Market Index $(100=2005)$ & 95.59 & 39.07 & 32.44 & 247.81 \\
\hline
\end{tabular}

Summary statistics are calculated over a sample of 500 observations from 9 countries, unless otherwise noted. (a) When applicable, the inflation target is defined as the midpoint of target range or the upper bound of an asymmetric target. (b) Calculated over a sample of 560 observations from 10 countries. (c) These financial stability indicators report the first lag of indicators calculated based on gap measures smoothed over the contemporaneous value and 4 lags (for equity) or 8 lags (for all other indicators) of the gap measure. 
Table A3: Taylor Rule Estimation with Financial Stability Indicators — Robustness Checks, 2000Q1-2014Q4

\begin{tabular}{|c|c|c|c|c|c|c|c|c|c|c|}
\hline & (1) & $(2)$ & (3) & (4) & $(5)$ & $(6)$ & (7) & (8) & (9) & (10) \\
\hline Panel I & \multicolumn{2}{|c|}{ 2nd Lag for Fin. Stab. } & \multicolumn{2}{|c|}{ 1st Lag for FSO Index } & \multicolumn{2}{|c|}{ 1st Lag for Macro Vars. } & \multicolumn{2}{|c|}{ CPI Inflation } & \multicolumn{2}{|c|}{ National Inflation } \\
\hline L1.Credit Gap & $\begin{array}{c}-2.006^{* * *} \\
(0.00)\end{array}$ & $\begin{array}{c}-1.226^{* * *} \\
(0.00)\end{array}$ & $\begin{array}{c}-1.948^{* * *} \\
(0.01)\end{array}$ & $\begin{array}{r}-0.580 \\
(0.16)\end{array}$ & $\begin{array}{c}-2.041^{* * *} \\
(0.00)\end{array}$ & $\begin{array}{c}-0.979^{* *} \\
(0.02)\end{array}$ & $\begin{array}{c}-2.130^{* * *} \\
(0.00)\end{array}$ & $\begin{array}{c}-0.876^{* *} \\
(0.03)\end{array}$ & $\begin{array}{c}-2.135^{* * *} \\
(0.00)\end{array}$ & $\begin{array}{c}-0.886^{* *} \\
(0.03)\end{array}$ \\
\hline L1.Credit Gap x Index & $\begin{array}{c}1.547^{* * *} \\
(0.00)\end{array}$ & $\begin{array}{c}0.828^{* * *} \\
(0.00)\end{array}$ & $\begin{array}{c}1.516^{* * *} \\
(0.00)\end{array}$ & $\begin{array}{c}0.473^{* *} \\
(0.05)\end{array}$ & $\begin{array}{c}1.580^{* * *} \\
(0.00)\end{array}$ & $\begin{array}{c}0.713^{* * *} \\
(0.00)\end{array}$ & $\begin{array}{c}1.548^{* * *} \\
(0.00)\end{array}$ & $\begin{array}{c}0.654^{* * *} \\
(0.01)\end{array}$ & $\begin{array}{c}1.591^{* * *} \\
(0.00)\end{array}$ & $\begin{array}{c}0.659^{* * *} \\
(0.01)\end{array}$ \\
\hline Total FS Effect, 25pctl & -0.301 & $-0.314^{* *}$ & -0.269 & -0.056 & -0.302 & -0.194 & -0.443 & -0.164 & -0.401 & -0.168 \\
\hline Total FS Effect, 75 pctl & $0.760^{* * *}$ & $0.254^{* *}$ & $0.762^{* * *}$ & $0.265^{* * *}$ & $0.783^{* * *}$ & $0.296^{* * *}$ & $0.638^{* * *}$ & $0.293^{* * *}$ & $0.709^{* * *}$ & $0.292^{* * *}$ \\
\hline $\mathrm{N}$ & 500 & 500 & 495 & 495 & 499 & 499 & 511 & 511 & 511 & 511 \\
\hline Panel II & \multicolumn{2}{|c|}{ OECD Output Gap } & \multicolumn{2}{|c|}{ 1-sided HP for OPG } & \multicolumn{2}{|c|}{ Growth Term } & \multicolumn{2}{|c|}{ Real Eff. Exchange Rate } & \multicolumn{2}{|c|}{ Incl. all U.K. \& NOR obs } \\
\hline L1.Credit Gap & $\begin{array}{c}-1.617^{* * *} \\
(0.01)\end{array}$ & $\begin{array}{c}-0.605^{*} \\
(0.07)\end{array}$ & $\begin{array}{c}-1.995^{* * *} \\
(0.00)\end{array}$ & $\begin{array}{c}-1.081^{* * *} \\
(0.00)\end{array}$ & $\begin{array}{c}-1.844^{* * *} \\
(0.01)\end{array}$ & $\begin{array}{c}-1.012^{* *} \\
(0.02)\end{array}$ & $\begin{array}{c}-2.037^{* * *} \\
(0.00)\end{array}$ & $\begin{array}{c}-0.741^{*} \\
(0.06)\end{array}$ & $\begin{array}{c}-1.973^{* * *} \\
(0.00)\end{array}$ & $\begin{array}{c}-0.931^{* *} \\
(0.03)\end{array}$ \\
\hline L1.Credit Gap x Index & $\begin{array}{c}1.367^{* * *} \\
(0.00)\end{array}$ & $\begin{array}{c}0.517^{* *} \\
(0.01)\end{array}$ & $\begin{array}{c}1.558^{* * *} \\
(0.00)\end{array}$ & $\begin{array}{c}0.786^{* * *} \\
(0.00)\end{array}$ & $\begin{array}{c}1.424^{* * *} \\
(0.00)\end{array}$ & $\begin{array}{c}0.759^{* * *} \\
(0.00)\end{array}$ & $\begin{array}{c}1.576^{* * *} \\
(0.00)\end{array}$ & $\begin{array}{c}0.566^{* *} \\
(0.01)\end{array}$ & $\begin{array}{c}1.539^{* * *} \\
(0.00)\end{array}$ & $\begin{array}{c}0.683^{* * *} \\
(0.01)\end{array}$ \\
\hline Total FS Effect, 25pctl & -0.112 & -0.036 & -0.278 & -0.215 & -0.275 & -0.176 & -0.301 & -0.118 & -0.212 & -0.150 \\
\hline Total FS Effect, 75pctl & $0.826^{* * *}$ & $0.318^{* * *}$ & $0.791^{* * *}$ & $0.325^{* * *}$ & $0.702^{* * *}$ & $0.345^{* * *}$ & $0.781^{* * *}$ & $0.270^{* * *}$ & $0.757^{* * *}$ & $0.280^{* * *}$ \\
\hline $\mathrm{N}$ & 500 & 500 & 500 & 500 & 500 & 500 & 500 & 500 & 529 & 529 \\
\hline Panel III & \multicolumn{2}{|c|}{ Alt. 3rd FSO Index Dim. } & \multicolumn{2}{|c|}{ 4-Dim. FSO Index } & \multicolumn{2}{|c|}{ Early Sample (until 07Q4) } & \multicolumn{2}{|c|}{ Late Sample (from 08Q1) } & \multicolumn{2}{|c|}{ Exclude Fin. Crisis } \\
\hline L1.Credit Gap & $\begin{array}{c}-1.576^{* *} \\
(0.01)\end{array}$ & $\begin{array}{c}-0.923^{* *} \\
(0.03)\end{array}$ & $\begin{array}{c}-1.463^{* *} \\
(0.01)\end{array}$ & $\begin{array}{c}-0.786^{*} \\
(0.05)\end{array}$ & $\begin{array}{c}-1.161^{*} \\
(0.09)\end{array}$ & $\begin{array}{c}-0.933^{*} \\
(0.07)\end{array}$ & $\begin{array}{c}-3.591^{* * *} \\
(0.00)\end{array}$ & $\begin{array}{c}-0.924^{*} \\
(0.08)\end{array}$ & $\begin{array}{l}-0.985 \\
(0.11)\end{array}$ & $\begin{array}{c}-0.869 \\
(0.11)\end{array}$ \\
\hline L1.Credit Gap x Index & $\begin{array}{c}1.283^{* * *} \\
(0.00) \\
\end{array}$ & $\begin{array}{c}0.683^{* * *} \\
(0.01)\end{array}$ & $\begin{array}{c}0.877^{* * *} \\
(0.00) \\
\end{array}$ & $\begin{array}{c}0.414^{* *} \\
(0.02) \\
\end{array}$ & $\begin{array}{c}1.132^{* *} \\
(0.01) \\
\end{array}$ & $\begin{array}{c}0.866^{* *} \\
(0.01) \\
\end{array}$ & $\begin{array}{c}2.304^{* * *} \\
(0.00) \\
\end{array}$ & $\begin{array}{c}0.566^{* *} \\
(0.05) \\
\end{array}$ & $\begin{array}{c}0.913^{* *} \\
(0.02)\end{array}$ & $\begin{array}{c}0.710^{* *} \\
(0.03)\end{array}$ \\
\hline Total FS Effect, 25pctl & -0.176 & -0.179 & -0.288 & -0.231 & -0.141 & -0.153 & -0.135 & -0.076 & -0.072 & -0.158 \\
\hline Total FS Effect, 75pctl & $0.718^{* * *}$ & $0.297 * * *$ & $0.715^{* * *}$ & $0.242^{* *}$ & $0.678^{* * *}$ & $0.475^{* * *}$ & $0.812^{* * *}$ & $0.157^{*}$ & $0.590 * * *$ & $0.357 * * *$ \\
\hline $\mathrm{N}$ & 500 & 500 & 500 & 500 & 248 & 248 & 252 & 252 & 392 & 392 \\
\hline Macro Variables & Yes & Yes & Yes & Yes & Yes & Yes & Yes & Yes & Yes & Yes \\
\hline Macro x Index & Yes & Yes & Yes & Yes & Yes & Yes & Yes & Yes & Yes & Yes \\
\hline Time Fixed Effects & Yes & Yes & Yes & Yes & Yes & Yes & Yes & Yes & Yes & Yes \\
\hline Country Fixed Effects & No & Yes & No & Yes & No & Yes & No & Yes & No & Yes \\
\hline
\end{tabular}

All specifications are estimated for 9 countries. The credit gap measure is smoothed over 8 lags.

All specifications include a constant. p-values in parentheses. ${ }^{*} p<0.10,{ }^{* *} p<0.05,{ }^{* * *} p<0.01$ 
Table A4: Taylor Rule Estimation at Different Thresholds and Smoothing Parameters of the Credit Gap Financial Stability Indicator, 2000Q1-2014Q4

\begin{tabular}{|c|c|c|c|c|c|c|c|c|c|c|}
\hline & \multicolumn{2}{|c|}{ Credit Gap (2pp) } & \multicolumn{2}{|c|}{ Credit Gap (4pp) } & \multicolumn{2}{|c|}{ Credit Gap (6pp) } & \multicolumn{2}{|c|}{ Credit Gap (8pp) } & \multicolumn{2}{|c|}{ Credit Gap (10pp) } \\
\hline & $(1)$ & $(2)$ & $(3)$ & $(4)$ & $(5)$ & $(6)$ & $(7)$ & $(8)$ & $(9)$ & $(10)$ \\
\hline \multicolumn{11}{|c|}{ Panel I: Memo - Smoothed over 8 lags } \\
\hline \multicolumn{11}{|c|}{ Panel II: Smoothed over 6 lags } \\
\hline L1.Credit Gap & $\begin{array}{l}-0.333 \\
(0.47)\end{array}$ & $\begin{array}{l}-0.343 \\
(0.17)\end{array}$ & $\begin{array}{c}-1.459^{* * *} \\
(0.00)\end{array}$ & $\begin{array}{c}-0.428^{*} \\
(0.07)\end{array}$ & $\begin{array}{c}-2.070^{* * *} \\
(0.00)\end{array}$ & $\begin{array}{c}-0.481^{*} \\
(0.10)\end{array}$ & $\begin{array}{c}-1.896^{* * *} \\
(0.01)\end{array}$ & $\begin{array}{c}-0.619 \\
(0.23)\end{array}$ & $\begin{array}{c}-3.758^{* * *} \\
(0.00)\end{array}$ & $\begin{array}{l}-1.003 \\
(0.25)\end{array}$ \\
\hline L1.Credit Gap x Index & $\begin{array}{c}0.635^{* *} \\
(0.03)\end{array}$ & $\begin{array}{c}0.415^{* * *} \\
(0.01)\end{array}$ & $\begin{array}{c}1.282^{* * *} \\
(0.00)\end{array}$ & $\begin{array}{c}0.488^{* * *} \\
(0.00)\end{array}$ & $\begin{array}{c}1.611^{* * *} \\
(0.00)\end{array}$ & $\begin{array}{c}0.475^{* *} \\
(0.01)\end{array}$ & $\begin{array}{c}1.477^{* * *} \\
(0.00)\end{array}$ & $\begin{array}{l}0.520^{*} \\
(0.09)\end{array}$ & $\begin{array}{c}2.585^{* * *} \\
(0.00)\end{array}$ & $\begin{array}{l}0.748 \\
(0.13)\end{array}$ \\
\hline Total FS Effect, 25pctl & $0.366^{* *}$ & $\begin{array}{l}0.114 \\
0.200 * * *\end{array}$ & $\begin{array}{l}-0.047 \\
0.22 * * *\end{array}$ & 0.109 & $\begin{array}{l}-0.296^{*} \\
0810 * * *\end{array}$ & $\begin{array}{l}0.043 \\
0.60 * * *\end{array}$ & $\begin{array}{c}-0.269 \\
0.745 * * *\end{array}$ & -0.047 & $-0.910^{* *}$ & $\begin{array}{l}-0.179 \\
0225 * * *\end{array}$ \\
\hline Total FS Effect, 75pctl & $0.802^{* * *}$ & $0.399^{* * *}$ & $0.832^{* * *}$ & $0.443^{* * *}$ & $0.810^{* * *}$ & $0.369^{* * *}$ & $0.745^{* * *}$ & $0.309^{* * *}$ & $0.864^{* * *}$ & $0.335^{* * *}$ \\
\hline \multicolumn{11}{|c|}{ Panel II: Smoothed over 4 lags } \\
\hline L1.Credit Gap & $\begin{array}{c}-0.524 \\
(0.25)\end{array}$ & $\begin{array}{l}-0.150 \\
(0.55)\end{array}$ & $\begin{array}{c}-1.583^{* * *} \\
(0.00)\end{array}$ & $\begin{array}{c}-0.452^{*} \\
(0.06)\end{array}$ & $\begin{array}{c}-1.684^{* * *} \\
(0.00)\end{array}$ & $\begin{array}{l}-0.356 \\
(0.20)\end{array}$ & $\begin{array}{c}-1.916^{* * *} \\
(0.00)\end{array}$ & $\begin{array}{r}-0.450 \\
(0.39)\end{array}$ & $\begin{array}{c}-3.981^{* * *} \\
(0.00)\end{array}$ & $\begin{array}{l}-0.872 \\
(0.29)\end{array}$ \\
\hline L1.Credit Gap x Index & $\begin{array}{c}0.739^{* *} \\
(0.01)\end{array}$ & $\begin{array}{c}0.316^{* *} \\
(0.05)\end{array}$ & $\begin{array}{c}1.304^{* * *} \\
(0.00)\end{array}$ & $\begin{array}{c}0.429^{* * *} \\
(0.00)\end{array}$ & $\begin{array}{c}1.428^{* * *} \\
(0.00)\end{array}$ & $\begin{array}{c}0.384^{* *} \\
(0.03)\end{array}$ & $\begin{array}{c}1.558^{* * *} \\
(0.00)\end{array}$ & $\begin{array}{l}0.482 \\
(0.12)\end{array}$ & $\begin{array}{c}2.738^{* * *} \\
(0.00)\end{array}$ & $\begin{array}{l}0.717 \\
(0.13)\end{array}$ \\
\hline Total FS Effect, 25pctl & $0.290^{*}$ & $0.198^{*}$ & -0.146 & 0.021 & -0.111 & 0.067 & -0.200 & 0.080 & $-0.965^{* *}$ & -0.082 \\
\hline Total FS Effect, 75pctl & $0.798^{* * *}$ & $0.415^{* * *}$ & $0.749^{* * *}$ & $0.315^{* * *}$ & $0.869^{* * *}$ & $0.330^{* * *}$ & $0.869 * * *$ & $0.411^{* * *}$ & $0.915^{* * *}$ & $0.410^{* * *}$ \\
\hline Macro Variables & Yes & Yes & Yes & Yes & Yes & Yes & Yes & Yes & Yes & Yes \\
\hline Macro x Index & Yes & Yes & Yes & Yes & Yes & Yes & Yes & Yes & Yes & Yes \\
\hline Time Fixed Effects & Yes & Yes & Yes & Yes & Yes & Yes & Yes & Yes & Yes & Yes \\
\hline Country Fixed Effects & No & Yes & No & Yes & No & Yes & No & Yes & No & Yes \\
\hline $\mathrm{N}$ & 500 & 500 & 500 & 500 & 500 & 500 & 500 & 500 & 500 & 500 \\
\hline Countries & 9 & 9 & 9 & 9 & 9 & 9 & 9 & 9 & 9 & 9 \\
\hline
\end{tabular}

Threshold values are reported in percentage points (pp). As throughout the paper, financial stability indicators are calculated from credit gap measures that are smoothed over the given number of lags as well as the contemporaneous value. $\mathrm{R}^{2}$ values are from 0.67 to 0.69 for specifications without country fixed effects, and 0.89 for those with country fixed effects. All specifications include a constant. p-values in parentheses. ${ }^{*} p<0.10,{ }^{* *} p<0.05,{ }^{* * *} p<0.01$ 
Table A5: Taylor Rule Estimation with Financial Stability Indicators of Real House and Equity Price Gaps, 2000Q1-2014Q4

\begin{tabular}{|c|c|c|c|c|}
\hline & (1) & $(2)$ & (3) & (4) \\
\hline Panel I: Real House Price (HP) Gap & $\mathrm{HP}(2 \mathrm{pp})$ & $\mathrm{HP}(4 \mathrm{pp})$ & $\mathrm{HP}(6 \mathrm{pp})$ & $\mathrm{HP}(8 \mathrm{pp})$ \\
\hline L1. House Price Gap & $\begin{array}{l}-0.261 \\
(0.52)\end{array}$ & $\begin{array}{r}-0.426 \\
(0.30)\end{array}$ & $\begin{array}{l}-0.627 \\
(0.15)\end{array}$ & $\begin{array}{l}-0.172 \\
(0.74)\end{array}$ \\
\hline L1. House Price Gap x Index & $\begin{array}{c}0.752^{* * *} \\
(0.01)\end{array}$ & $\begin{array}{c}0.819^{* * *} \\
(0.00)\end{array}$ & $\begin{array}{c}0.774^{* * *} \\
(0.01)\end{array}$ & $\begin{array}{l}0.448 \\
(0.15)\end{array}$ \\
\hline $\begin{array}{l}\text { Total FS Effect, } 25 \text { pctl } \\
\text { Total FS Effect, } 75 \text { pctl }\end{array}$ & $\begin{array}{l}0.568^{* * *} \\
1.084^{* * *}\end{array}$ & $\begin{array}{l}0.476^{* * *} \\
1.038^{* * *}\end{array}$ & $\begin{array}{c}0.225 \\
0.756^{* * *}\end{array}$ & $\begin{array}{c}0.322^{*} \\
0.630^{* * *}\end{array}$ \\
\hline Panel II: Real Equity Price (EP) Gap & $\mathrm{EP}(5 \mathrm{pp})$ & $\mathrm{EP}(10 \mathrm{pp})$ & $\mathrm{EP}(15 \mathrm{pp})$ & $\mathrm{EP}(20 \mathrm{pp})$ \\
\hline L1. Equity Price Gap & $\begin{array}{c}1.935^{* * *} \\
(0.00)\end{array}$ & $\begin{array}{c}1.645^{* * *} \\
(0.00)\end{array}$ & $\begin{array}{c}1.765^{* * *} \\
(0.00)\end{array}$ & $\begin{array}{c}1.662^{* * *} \\
(0.00)\end{array}$ \\
\hline L1. Equity Price Gap x Index & $\begin{array}{c}-0.716^{* *} \\
(0.02)\end{array}$ & $\begin{array}{r}-0.501 \\
(0.14)\end{array}$ & $\begin{array}{l}-0.463 \\
(0.19)\end{array}$ & $\begin{array}{l}-0.374 \\
(0.31)\end{array}$ \\
\hline $\begin{array}{l}\text { Total FS Effect, } 25 \text { pctl } \\
\text { Total FS Effect, } 75 \text { pctl }\end{array}$ & $\begin{array}{l}1.146^{* * *} \\
0.655^{* * *}\end{array}$ & $\begin{array}{l}1.093^{* * *} \\
0.749^{* * *}\end{array}$ & $\begin{array}{l}1.256^{* * *} \\
0.938^{* * *}\end{array}$ & $\begin{array}{l}1.249^{* * *} \\
0.992^{* * *}\end{array}$ \\
\hline $\begin{array}{l}\text { Macro Variables } \\
\text { Macro x Index } \\
\text { Time Fixed Effects }\end{array}$ & $\begin{array}{l}\text { Yes } \\
\text { Yes } \\
\text { Yes }\end{array}$ & $\begin{array}{l}\text { Yes } \\
\text { Yes } \\
\text { Yes }\end{array}$ & $\begin{array}{l}\text { Yes } \\
\text { Yes } \\
\text { Yes }\end{array}$ & $\begin{array}{l}\text { Yes } \\
\text { Yes } \\
\text { Yes }\end{array}$ \\
\hline $\begin{array}{l}\mathrm{N} \\
\text { Countries }\end{array}$ & $\begin{array}{c}500 \\
9\end{array}$ & $\begin{array}{c}500 \\
9\end{array}$ & $\begin{array}{c}500 \\
9\end{array}$ & $\begin{array}{c}500 \\
9\end{array}$ \\
\hline
\end{tabular}

The house and equity price gap indicators reflect measures that are smoothed over 8 and 4 lags, respectively, at various thresholds measured in percentage points (pp). $\mathrm{R}^{2}$ values are from 0.67 to 0.68 . All specifications include a constant. p-values in parentheses.

${ }^{*} p<0.10,{ }^{* *} p<0.05,{ }^{* * *} p<0.01$ 
Table A6: Taylor Rule Estimation with Financial Stability Indicators at Different Thresholds, including Japan 2000Q1-2014Q4

\begin{tabular}{|c|c|c|c|c|c|c|c|c|c|}
\hline \multirow[b]{3}{*}{ Thresholds: } & \multicolumn{3}{|c|}{ Credit Gap } & \multicolumn{3}{|c|}{ Credit \& Real House Price Gaps } & \multicolumn{3}{|c|}{ Credit \& Real Equity Price Gaps } \\
\hline & $(1)$ & $(2)$ & $(3)$ & $(4)$ & $(5)$ & $(6)$ & $(7)$ & $(8)$ & $(9)$ \\
\hline & $2 \mathrm{pp}$ & $4 \mathrm{pp}$ & $6 \mathrm{pp}$ & $2 \mathrm{pp} \& 2 \mathrm{pp}$ & $4 p p \& 4 p p$ & $6 \mathrm{pp} \& 6 \mathrm{pp}$ & $2 \mathrm{pp} \& 5 \mathrm{pp}$ & $4 \mathrm{pp} \& 10 \mathrm{pp}$ & $6 \mathrm{pp} \& 20 \mathrm{pp}$ \\
\hline Output Gap & $\begin{array}{c}0.695^{* * *} \\
(0.00)\end{array}$ & $\begin{array}{c}0.677^{* * *} \\
(0.00)\end{array}$ & $\begin{array}{c}0.678^{* * *} \\
(0.00)\end{array}$ & $\begin{array}{c}0.689^{* * *} \\
(0.00)\end{array}$ & $\begin{array}{c}0.690^{* * *} \\
(0.00)\end{array}$ & $\begin{array}{c}0.687^{* * *} \\
(0.00)\end{array}$ & $\begin{array}{c}0.665^{* * *} \\
(0.00)\end{array}$ & $\begin{array}{c}0.658^{* * *} \\
(0.00)\end{array}$ & $\begin{array}{c}0.659^{* * *} \\
(0.00)\end{array}$ \\
\hline Inflation Gap & $\begin{array}{c}1.235^{* * *} \\
(0.00)\end{array}$ & $\begin{array}{c}1.280^{* * *} \\
(0.00)\end{array}$ & $\begin{array}{c}1.262^{* * *} \\
(0.00)\end{array}$ & $\begin{array}{c}1.177^{* * *} \\
(0.00)\end{array}$ & $\begin{array}{c}1.191^{* * *} \\
(0.00)\end{array}$ & $\begin{array}{c}1.132^{* * *} \\
(0.00)\end{array}$ & $\begin{array}{c}1.130^{* * *} \\
(0.00)\end{array}$ & $\begin{array}{c}1.166^{* * *} \\
(0.00)\end{array}$ & $\begin{array}{c}1.197^{* * *} \\
(0.00)\end{array}$ \\
\hline L1. Fin. Stability Indicator & $\begin{array}{l}-0.084 \\
(0.74)\end{array}$ & $\begin{array}{l}-0.195 \\
(0.41)\end{array}$ & $\begin{array}{l}-0.346 \\
(0.22)\end{array}$ & $\begin{array}{l}-0.091 \\
(0.70)\end{array}$ & $\begin{array}{c}-0.204 \\
(0.46)\end{array}$ & $\begin{array}{l}0.124 \\
(0.71)\end{array}$ & $\begin{array}{c}0.768^{* *} \\
(0.02)\end{array}$ & $\begin{array}{c}0.964^{* * *} \\
(0.01)\end{array}$ & $\begin{array}{c}1.000^{* *} \\
(0.03)\end{array}$ \\
\hline FSO Index & $\begin{array}{c}-0.349^{* *} \\
(0.03)\end{array}$ & $\begin{array}{c}-0.361^{* *} \\
(0.01)\end{array}$ & $\begin{array}{c}-0.341^{* *} \\
(0.02)\end{array}$ & $\begin{array}{c}-0.318^{* *} \\
(0.03)\end{array}$ & $\begin{array}{c}-0.330^{* *} \\
(0.02)\end{array}$ & $\begin{array}{c}-0.270^{*} \\
(0.06)\end{array}$ & $\begin{array}{c}-0.302^{* *} \\
(0.04)\end{array}$ & $\begin{array}{c}-0.290^{*} \\
(0.05)\end{array}$ & $\begin{array}{c}-0.281^{*} \\
(0.06)\end{array}$ \\
\hline L1. Fin. Stability Indicator $x$ Index & $\begin{array}{c}0.266^{*} \\
(0.08)\end{array}$ & $\begin{array}{c}0.330^{* *} \\
(0.03)\end{array}$ & $\begin{array}{l}0.340^{*} \\
(0.05)\end{array}$ & $\begin{array}{c}0.241 \\
(0.10)\end{array}$ & $\begin{array}{l}0.301^{*} \\
(0.08)\end{array}$ & $\begin{array}{l}0.064 \\
(0.75)\end{array}$ & $\begin{array}{l}-0.186 \\
(0.42)\end{array}$ & $\begin{array}{c}-0.437^{*} \\
(0.05)\end{array}$ & $\begin{array}{l}-0.197 \\
(0.51)\end{array}$ \\
\hline O.Gap x Index & $\begin{array}{c}-0.316^{* * *} \\
(0.00)\end{array}$ & $\begin{array}{c}-0.310^{* * *} \\
(0.00)\end{array}$ & $\begin{array}{c}-0.307^{* * *} \\
(0.00)\end{array}$ & $\begin{array}{c}-0.316^{* * *} \\
(0.00)\end{array}$ & $\begin{array}{c}-0.319^{* * *} \\
(0.00)\end{array}$ & $\begin{array}{c}-0.313^{* * *} \\
(0.00)\end{array}$ & $\begin{array}{c}-0.289^{* * *} \\
(0.00)\end{array}$ & $\begin{array}{c}-0.288^{* * *} \\
(0.00)\end{array}$ & $\begin{array}{c}-0.282^{* * *} \\
(0.00)\end{array}$ \\
\hline Inf. Gap x Index & $\begin{array}{c}-0.671^{* * *} \\
(0.00)\end{array}$ & $\begin{array}{c}-0.692^{* * *} \\
(0.00)\end{array}$ & $\begin{array}{c}-0.699^{* * *} \\
(0.00)\end{array}$ & $\begin{array}{c}-0.640^{* * *} \\
(0.00)\end{array}$ & $\begin{array}{c}-0.648^{* * *} \\
(0.00)\end{array}$ & $\begin{array}{c}-0.640^{* * *} \\
(0.00)\end{array}$ & $\begin{array}{c}-0.644^{* * *} \\
(0.00)\end{array}$ & $\begin{array}{c}-0.657^{* * *} \\
(0.00)\end{array}$ & $\begin{array}{c}-0.669^{* * *} \\
(0.00)\end{array}$ \\
\hline Time Fixed Effects & Yes & Yes & Yes & Yes & Yes & Yes & Yes & Yes & Yes \\
\hline Country Fixed Effects & Yes & Yes & Yes & Yes & Yes & Yes & Yes & Yes & Yes \\
\hline $\mathrm{R} 2$ & 0.88 & 0.88 & 0.88 & 0.88 & 0.88 & 0.88 & 0.89 & 0.88 & 0.88 \\
\hline $\mathrm{N}$ & 560 & 560 & 560 & 560 & 560 & 560 & 560 & 560 & 560 \\
\hline Countries & 10 & 10 & 10 & 10 & 10 & 10 & 10 & 10 & 10 \\
\hline Total FS Effect, 25pctl & $0.228^{* *}$ & $0.192^{* *}$ & 0.053 & $0.192^{* *}$ & 0.150 & 0.199 & $0.550^{* * *}$ & $0.451^{* *}$ & $0.768^{* * *}$ \\
\hline p-value & 0.03 & 0.04 & 0.61 & 0.02 & 0.12 & 0.10 & 0.00 & 0.01 & 0.00 \\
\hline Total FS Effect, 75pctl & $0.425^{* * *}$ & $0.436^{* * *}$ & $0.304^{* * *}$ & $0.369^{* * *}$ & $0.372^{* * *}$ & $0.246^{* *}$ & $0.413^{* *}$ & 0.128 & $0.623^{* *}$ \\
\hline $\mathrm{p}$-value & 0.00 & 0.00 & 0.00 & 0.00 & 0.00 & 0.02 & 0.03 & 0.52 & 0.01 \\
\hline
\end{tabular}

Financial stability indicators are calculated from gap measures smoothed over 8 lags (columns 1 to 6 ) or 4 lags (columns 7 to 9 ). For composite FS indicators, the first and second reported threshold values indicate the percentage point (pp) cut-offs for the credit and asset price gaps,

respectively. All specifications include a constant. p-values in parentheses. ${ }^{*} p<0.10,{ }^{* *} p<0.05,{ }^{* * *} p<0.01$ 


\subsubsection{Additional Figures}

Figure A1: The Impact of an Interest Rate Change on Financial Stability

Following a table in the appendix of the International Monetary Fund (IMF 2013), we start our analysis by assessing the transmission mechanism of monetary policy and all its intersections with the financial system. ${ }^{1}$ For each transmission channel, we describe the net effect on financial stability resulting from an increase in the interest rate.

- Risk-taking channel: An increase in the interest rate reduces the incentive of banks and firms to engage in more risky investments as part of their "search for yield." Hence, financial stability increases.

- Risk-shifting channel: An increase in the interest rate increases the incentive of almostbankrupt banks and firms to take on more risks and increase their payout in the survival-case ("gambling for resurrection"). Hence, financial stability decreases.

- Balance sheet channel ("broad credit channel"): An increase in interest rates deteriorates the balance sheets of firms and thus increases the external finance premium. Ceteris paribus, firm defaults become more likely. Hence, financial stability decreases.

- Bank lending channel ("narrow credit channel"): An increase in interest rates deteriorates the quality of assets on the bank balance sheet and raises the refinancing costs for banks. Ceteris paribus, bank defaults become more likely. However, when credit growth is relatively high, the expansion in credit might be slowed down softly and financial stability increases. Hence, the overall effect on financial stability is ambiguous.

- Exchange rate channel: An increase in interest rates induces an appreciation of the domestic currency. This helps consumers, firms or banks that have taken out credit denominated in foreign currency. Hence, financial stability increases.

- Asset price channel: An increase in the interest rate reduces stock market wealth and housing wealth and thus could lead to a deterioration of household balance sheets. This effect reduces financial stability. However, when asset prices are relatively high, a boom in asset prices might be curbed softly and financial stability might increase. Hence, the overall effect on financial stability is ambiguous.

IMF (2013) also provides citations from the empirical literature that confirm the above shown effects of monetary policy on financial stability for the risk-taking, the risk-shifting, the balance sheet and the exchange rate channel. ${ }^{2}$ Hence, the net impact of an interest rate increase on financial stability is highly dependent on the structure and the financial market conditions of the economy and will eventually be an empirical question.

\footnotetext{
${ }^{1}$ We do not consider the interest rate channel (i.e., we abstract from inter-temporal substitution effects) and parts of the exchange rate channel (i.e., we abstract from the effect on net exports).

2 IMF (2013) does not investigate the effect of monetary policy on the bank lending channel. Also, the resulting effect of an interest rate increase on financial stability through the asset price channel is considered to be unambiguously negative.
} 
Figure A2: Determinants of Central Banks' Views Toward Financial Stability (Building on the Characterization in Smets (2014))

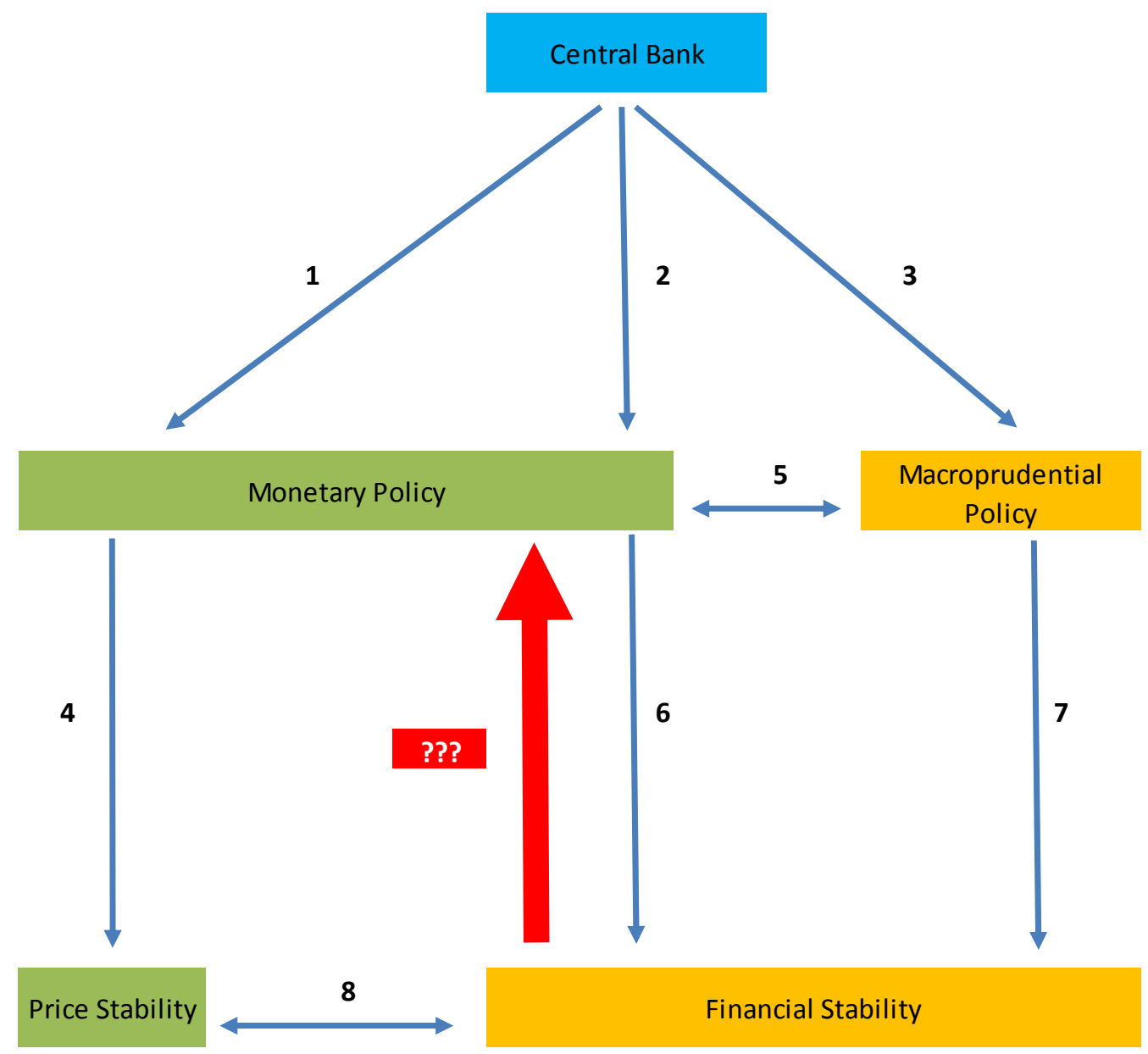

\section{Notes:}

The links are indicated by the blue arrows and describe the following relationships:

1. The central bank should be independent and have full control of the monetary policy tools

2. Depending on its mandate, the central bank is additionally allowed to use monetary policy to address financial stability concerns

3. Depending on the structure of financial stability supervision in the country, the central bank might have prior, shared, or subordinated access to macroprudential policies to address financial stability goals

4. This is the standard channel of monetary policy - it is not discussed further in this set-up

5. This link characterizes the interaction of monetary and macroprudential policies

6. This channel discusses the effectiveness of monetary policy instruments in addressing financial stability goals; in addition, it discusses potential (unwanted) spillovers from monetary policy on financial stability

7. This channel discusses the effectiveness and the potential side effects of macroprudential policies

8. This link characterizes the separability of the goals - price stability and financial stability 


\subsection{Index Construction}

\subsubsection{Statutory Dimension: Publication Dates of Financial Stability Reports}

The publication dates for the first financial stability reports are taken from the following sources:

- RBA: "This Financial Stability Review [March 2004] is the first occasion on which a more detailed assessment has been published in a stand-alone publication - a practice that will be continued half-yearly from now on."

- BoC: "The goal of the Financial System Review (FSR), which will be issued semi-annually by the Bank, is to share with financial system participants" [December 2002]

- ECB: "Since 2004 the ECB has published twice a year the Financial Stability Review" [December 2004]

- BoJ: "[July 2006:] The Bank of Japan began the publication of the Financial System Report last year"... "The announcement to start the publication of the Financial System Report (FSR) is another component of the [March 2005] statement. The FSR is comprised of two regular reports: one to evaluate the stability and functioning of the financial system; and the other to explain the Bank's policy. This report [August 2005] ... is the first issue of these reports."

- RBNZ: "The Bank published its first FSR in October 2004."

- Norges Bank: "Norges Bank has produced reports on financial stability since 1995. Since 1997, edited versions of these analyses have been published in Economic Bulletin. From this year [May 2000], the report will be published separately."

- Riksbank: "This is the first issue in the Riksbank's new series of reports on financial markets." [November 1997]

- SNB: "It [2004] is the second annual financial stability report published by the Swiss National Bank (SNB). For the 2003 edition, see the "Report on the Stability of the Financial System," SNB, Quarterly Bulletin, 2, June 2003, pp. 60-85, available at www.snb.ch." [data from 'as at the end of March 2004']

- BoE: "In the autumn of 1996 the Bank launched a new publication, the Financial Stability Review (FSR).... Initially, the FSR was produced in conjunction with the Securities and Investments Board and then, from 1998, with the Financial Services Authority...In 2006, to reflect a change in content and aims, the name was changed to the Financial Stability Report." [Oct/Nov 1996]

- Fed: No FSR. Since 2011, the Financial Stability Oversight Council (FSOC) has published an annual report that is similar to an FSR; while the Fed is represented on the FSOC, we do not count this report as an FSR because the Fed is not the sole institution responsible for its publication. In addition, the Office of Financial Research (an office within Treasury established to serve the FSOC) started publishing an annual report in 2012, which also assesses the state of the U.S. financial system and analyses threats to financial stability. 


\subsubsection{Regulatory Dimension}

For the values in the early part of our sample, we draw on information from three different publications and assign values of 0 (central bank is the sole regulator), 0.5 (central bank shares regulatory responsibility with another agency) and 1 (central bank only has a supportive role in designing regulation) according to the following information:

The values in 2000 and before:

Category "Bank regulation" in Table A ("Industrial economies: degree of central bank involvement in financial stability 'functions'") on page 378-379 in Sinclair, P.J.N., 2000. "Central banks and financial stability." Source: http://www.bankofengland.co.uk/archive/Documents/ historicpubs/qb/2000/qb000403.pdf

- The central bank of New Zealand is the sole regulator: We assign New Zealand a 0 for the year 2000 (and extend these values backward to the beginning of the sample)

- The central banks of Sweden, Canada, Australia, Norway, United Kingdom are not the sole regulator: We assign a value of 1 for these countries in the year 2000 (and extend the values of Sweden, Canada and Norway back to the beginning of the sample)

\section{The values in 2005 and before:}

Table 1 ("Location of Bank Regulatory Authority, Industrial countries (2005)") on page 666 in Copelovitch, M.S. and Singer, D.A., 2008. "Financial Regulation, Monetary Policy, and Inflation in the Industrialized World," The Journal of Politics, 70 (03), pp. 663-680. Source: http:// journals . cambridge .org/action/displayAbstract? fromPage=online\&aid=1927256

- New Zealand and, with some restrictions, the United States are listed as countries where the regulation authority is located in the central bank: We assign a value of 0 to New Zealand (and extend it back to the year 2000) and a value of 0.5 to the United States (and extend it back to the beginning of the sample)

- Australia, Canada, Norway, Sweden, Switzerland and the United Kingdom are countries where financial system regulation is conducted by a separate agency: We assign a value of 1 to all above listed countries (and extend it back to the year 2000 for Australia, Canada, Norway and Sweden, and we extend the values for Japan and Switzerland back to the beginning of the sample)

- The table also indicates that for Australia and for the United Kingdom, regulation was conducted in by the central bank before 1999: We assign a value of 0 for Australia and the United Kingdom during the period before 1999 with the following modifications: (a) for Australia: from 2008Q4 back; based on the footnote; (b) for the United Kingdom: from 2008Q1 back; because of alternative sources that locate the change to have taken place in June 2008

\section{The values in 2009 and before:}

Category "Grounding of the mandate for regulation making" in Table 2 ("Grounding of financial stability related mandates of central banks in law, extra-statutory statements or tradition") on page 7 in BIS, 2011, "Central Bank Governance and Financial Stability - A Report by a Study Group". Source: http://www.bis.org/publ/othp14.pdf 
- The order of countries (in increasing order of a grounded mandate for regulation) is Japan, Sweden and Australia, United Kingdom, ECB: We assign values of 1 to Japan, Australia and Sweden (and extend it back to 2005), a value of 0.5 to the ECB (and extend it back to the beginning of the sample), and a value of 1 to the U.K.

\section{Changes since 2009:}

We make the following changes based on central bank communications during the more recent period:

- We reduce the U.K.'s score from 1 to 0 in 2013Q2 to reflect the coming into force of the Financial Services Act (2012), which brought about major changes to the Bank of England's responsibility for financial regulation (established an independent Financial Policy Committee (FPC) at the Bank, a new prudential regulator as a subsidiary of the Bank, and created new responsibilities for the supervision of financial market infrastructure).

- We reduce Norway's score from 1 to 0.5 in 2013Q2 to reflect the adoption of new capital adequacy regulation for banks adopted by the Norwegian parliament, under which Norges Bank was tasked with drawing up a decision basis and issuing advice on the buffer level to the Ministry of Finance.

- We reduce Switzerland's score from 1 to 0.5 in 2011Q1, to reflect the Memorandum of Understanding in the area of financial stability and the exchange of information on financial market regulation between the Federal Department of Finance (FDF) and the Financial Market Supervisory Authority (FINMA) and the Swiss National Bank (SNB) on trilateral cooperation between the Swiss financial market authorities.

\subsubsection{View-Based Dimension}

Search Terms: Search terms used to identify financial stability-, inflation- and output gap-related references in monetary policy statements. Indicated by the following list:

- Financial Stability Target:

(i) Terms corresponding to our financial stability variables:

$\rightarrow$ "credit"

$\rightarrow$ "debt" (other than "sovereign debt," "public debt," or "government debt")

$\rightarrow$ "house/housing/property/dwelling price"

$\rightarrow$ "equity/asset/share/stock/stock market/spot price"

(ii) More general financial stability terms:

$\rightarrow$ "financial"

$\rightarrow$ "imbalance" (other than "global imbalance," "economic imbalance," "savings imbalance"; also excluded "financial imbalance," to avoid double counting with 'financial')

$$
\rightarrow \text { "bubble" }
$$

- Inflation Target:

$\rightarrow$ "flation" (e.g., picks up inflation, inflationary, disinflation, deflation) 
$\rightarrow$ "price" (other than the financial stability-related prices listed above and excluding "price inflation" to avoid double counting with 'flation')

- Output Target:

$$
\begin{aligned}
& \rightarrow \text { "output" } \\
& \rightarrow \text { "slack" } \\
& \rightarrow \text { "capacity" } \\
& \rightarrow \text { "excess supply, excess demand, aggregate supply, and aggregate demand" } \\
& \rightarrow \text { "resource utilisation/utilization" } \\
& \rightarrow \text { "employment" } \\
& \rightarrow \text { "labour/labor" } \\
& \rightarrow \text { "dual mandate" }
\end{aligned}
$$

Sources: Documents of each central bank that were searched for the above terms. Indicated by the following list:

- Reserve Bank of Australia (Australia): Monetary policy press releases, available at http: //www.rba.gov.au/monetary-policy/int-rate-decisions/index.html

- Bank of Canada (Canada): Monetary policy press releases, available at http://www. bankof canada.ca/press/press-releases

- European Central Bank (euro area): Introductory statements to press conference, available at https://www.ecb.europa.eu/press/pressconf/2015/html/index.en.html

- Bank of Japan (Japan): The "Monetary Policy for the Immediate Future" section of the Monetary Policy Meeting minutes, available at http://www.boj.or.jp/en/mopo/mpmsche_ minu/past.htm

- Reserve Bank of New Zealand (New Zealand): Monetary policy press releases, available at http://www.rbnz.govt.nz/monetary_policy/ocr

- Norges Bank (Norway): Introductory statement to press conference (January 2000-September 2003), monetary policy press releases (since October 2003), available at http://www . norges-bank. no/en/Monetary-policy/Monetary-policy-meetings

- Sveriges Riksbank (Sweden): Monetary policy press releases, available at http://www.riksbank. se/en/Monetary-policy/Forecasts-and-interest-rate-decisions/Repo -rate-decisions

- Swiss National Bank (Switzerland): Ad hoc monetary policy summaries (2000-2003), "quarterly assessment" (2004-2009), monetary policy assessment press releases (since 2010), available at http://www.snb.ch/en/iabout/monpol/id/monpol_current

- Bank of England (U.K.): The "immediate policy decision" section of the Monetary Policy Committee minutes, available at http://www.bankofengland.co.uk/monetarypolicy/ Pages/decisions.aspx

- Federal Reserve (U.S.): Monetary policy press releases, available at http://www.federal reserve.gov/monetarypolicy/fomccalendars.htm 